\begin{abstract}
AVISO
Em atenção aos artigos 11 e 96 da Lei no 9.279/96 (Lei da Propriedade Industrial) e em consonância com a Resolução CAD 005/2008 da Universidade de Brasília, informamos que o presente trabalho somente foi publicado na data indicada neste informativo. A respectiva defesa, para obtenção do título pretendido, foi realizada na modalidade de sessão fechada, conforme a documentação anexada, de forma que o requisito da novidade, exigida nos referidos artigos da Lei, foi devidamente preservado.
\end{abstract}

Data da entrega do trabalho: 24/08/2016

Data da publicação: 24/08/2018

Patrícia Nunes da Silva

Coordenadora da Coordenadoria de Gestão da Informação Digital 
UNIVERSIDADE DE BRASILIA - UNB

FACULDADE DE MEDICINA - UNB

PROGRAMA DE PÓS-GRADUAÇÃO EM PATOLOGIA MOLECULAR LABORATÓRIO DE ANÁLISES MOLECULARES DE PATÓGENOS - LAMP

DISSERTAÇÃO DE MESTRADO

AVALIAÇÃO DO ANTÍGENO METALOPEPTIDASE MITOCONDRIAL PARA DIAGNÓSTICO SOROLÓGICO DE LEISHMANIOSE VISCERAL

Hérick Sampaio Muller

Orientador: Dr. Carlos André Ornelas Ricart

Co-orientador: Dr. Vicente de Paulo Martins

Brasília - DF

2016 
Hérick Sampaio Muller

\title{
AVALIAÇÃO DO ANTÍGENO METALOPEPTIDASE MITOCONDRIAL PARA DIAGNÓSTICO SOROLÓGICO DE LEISHMANIOSE VISCERAL
}

\begin{abstract}
Dissertação apresentada como requisito parcial para a obtenção do título de Mestre pelo programa de Pós-Graduação em Patologia Molecular da Faculdade de Medicina, Universidade de Brasília.
\end{abstract}

Orientador: Dr. Carlos André Ornelas Ricart

Co-orientador: Vicente de Paulo Martins

Brasília - DF

2016 


\section{AVALIAÇÃO DO ANTÍGENO METALOPEPTIDASE MITOCONDRIAL PARA DIAGNÓSTICO SOROLÓGICO DE LEISHMANIOSE VISCERAL}

Dissertação apresentada como requisito parcial para a obtenção do título de Mestre pelo programa de Pós-Graduação em Patologia Molecular da Faculdade de Medicina, Universidade de Brasília.

Hérick Sampaio Muller

Dissertação aprovada em: 1

Comissão julgadora:

1ํMem. (Presidente):

Prof. Dr. Carlos André Ornelas Ricart (UnB)

2Membro:

Prof. ${ }^{a}$ Dra. Tatiana Amabile de Campos (UnB)

3ำ Membro:

Prof. ${ }^{2}$ Dra. Izabella Marques Dourado Bastos Charneau (UnB)

40 Membro (Suplente):

Prof. Dra. Carla Nunes de Araujo. (UnB) 
O presente trabalho foi realizado no Laboratório de Análises Moleculares de Patógenos, do Instituto de Ciências Biológicas da Universidade de Brasília.

Financiamento: FAPDF / FAHUB / CNPq / CAPES. 


\section{DEDICATÓRIA}

"Comece fazendo o que é necessário, depois o que é possível, e de repente você
estará fazendo o impossível"

São Francisco de Assis

A Deus, pela graça da vida.

Aos meus amados pais Maria e Geraldo.

Aos meus bons e sempre presentes tio Evilasio e tia Lucia.

Aos meus queridos irmãos Eduardo, Henrique e Elize.

A minha ruiva por todo apoio. 
Agradeço especialmente aos meus orientadores Dr. Vicente de Paulo Martins e Carlos Andre Ornelas Ricart por todos seus ensinamentos, pela oportunidade de aumentar meus conhecimentos e por nunca terem desistido de seu aluno.

Agradeço a Dra. Nadjar Nitz, Mariana Hecht e ao Professor Antonio Teixeira que me deram oportunidade de ingressar na vida cientifica, sempre com carinho e sabedoria em suas palavras.

Agradeço ao Dr. Alessandro O. Sousa e Adriano Rios e Tamires Vital por terem me apadrinhado na ciência, por seus conselhos, explicações e muito bom humor em suas brincadeiras.

Nesta trajetória, houve muitas pessoas com quem fiz amizades e me ajudaram de uma maneira que jamais esquecerei: ao grande Rafael Rocha, Willie Lili, Adriano, Alessandro, Agnelo Agnes, Prof. Teixeira, à Juliana Jubs, Luis LuLu Maia por todas as conversas, debates e dicas, Lucas, Marcio, à Rafaela sargenta, à Laura, ao Nicholas de Mojana pela paciência e dicas, ao grande C.A por toda bondade, à Profa. Tatiana e seus puxões de orelha, às Profas. Flávia, Carla, Isabela e Beatriz por me ajudarem a dar continuidade aos experimentos em seus laboratórios, à Clênia Yanna e Camila por sempre estarem de braços abertos para me ajudar, ao perigoso Anderson Dedé e ao todo poderoso Prof. Vivi e sua esposa Dra. Adriana por serem mais que professores em minha jornada.

A todos meus amigos e familiares que me apoiaram (eles sabem quem são).

Agradeço a minha família: meus irmãos Eduardo, Henrique, e minha irmã Elize, minha Mãe Maria, meu Pai Geraldo, ao meu tio Evilasio e a minha tia Lucia por sempre estarem me ajudando e incentivando a seguir em frente.

Agradeço de todo coração a Jessica Ribeiro, que me ajudou e apoiou sempre e sempre. Estando sempre ao meu lado, desde a elaborar aulas que ela achava tão chatas ou indo me resgatar do laboratório. Obrigado minha princesa de cabelos rubros. 


\section{RESUMO}

A leishmaniose é uma antropozoonose que possui diferentes manifestações clinicas, sendo transmitida durante o repasto sanguíneo de flebotomíneos e causada por várias espécies de parasitos do gênero Leishmania. Esta doença causa grandes agravos na saúde humana em escala global, com altas taxas de mortalidade anualmente. Inúmeros fatores de risco impulsionam a transmissão do parasito para áreas anteriormente não endêmicas provocados tanto pelo ser humano quanto por variações naturais do ambiente. O controle da leishmaniose visceral (LV) no Brasil se faz por meio da deteç̧ão e eliminação dos reservatórios da doença, controle das populações de vetor, prevenção do contato com vetores infectados e tratamento dos casos humanos. No entanto, essas medidas são aplicadas frequentemente de forma isolada e tem-se mostrado limitadas. Como consequência, observa-se a manutenção ou mesmo expansão da LV para áreas onde sua ocorrência não era registrada. Nesse contexto, medidas que visem à redução da transmissão e suas aplicações de forma integrada são de fundamental importância, tais como o diagnóstico precoce e com alta sensibilidade dos humanos e dos cães infectados, tratamento eficaz e o emprego de vacinas. O diagnóstico tradicional da LV é baseado na presença de anticorpos antiLeishmania e o padrão-ouro é a visualização de formas amastigotas do parasito em amostras biológicas. No entanto, a introdução da vacinação de cães nos últimos anos gera a necessidade de novos métodos sorológicos capazes de diferenciar entre animais vacinados e infectados. Assim, o objetivo do presente trabalho foi avaliar a metalo-peptidase zinco dependente, Clã ME, Família M16 secretada de L. infantum como marcador para diagnóstico sorológico de LV. A análise in sílico revelou que a proteína teria $47,35 \%$ de resíduos de aminoácidos expondo sua superfície ao solvente e nestas áreas foram encontradas possíveis zonas para epitopos de células $B$, sítios de glicosilação e fosforilação. A expressão das proteínas em sistemas diferentes possibilitou avaliar a imunogenicidade das proteínas heterólogas com e sem modificações pós-traducionais contra soro de cães infectados e sadios. O resultado do ensaio de ELISA mostrou altos índices de anticorpos específicos contra as proteínas heterólogas e a comparação dos resultados indicou que a proteína heteróloga expressa em modelo procarioto identificou todos os animais infectados nas diluições 1:50 e 1:100 de soro. Os dados estatísticos do teste t mostraram $p$ value < 0.01, dando credibilidade na hipótese de uso desta proteína em possível diagnóstico para LV. O estudo realizado apresenta informações relevantes sobre o uso da metalo- 
peptidase estudada para que possa ser associada ao melhoramento do diagnóstico da LV. Testes para definição da sensibilidade e especifidade fazem-se necessários em futuros trabalhos.

Palavras chave: Leishmania, leishmaniose, metalo-peptidase, proteína heteróloga, diagnóstico. 


\section{ABSTRACT}

Leishmaniasis is a anthropozoonosis with different clinical manifestations, being transmitted by sandfly during blood feeding and caused by several species of parasites of the genus Leishmania. This disease causes major health problems on a global scale, with high mortality rates annually. Several risk factors drive the transmission of the parasite to areas not previously endemic due to man activities and by natural environmental variations. Control of visceral leishmaniasis (VL) in Brazil is made through the detection and elimination of disease reservoirs, control of vector populations, preventing contact with infected vectors and treatment of human cases. However, these measures are often applied in isolation and has shown limited efficacy. As a result, there is the maintenance or expansion of the $\mathrm{VL}$ to areas where their occurrence was not recorded. In this context, measures aimed to reduce transmission and its applications in an integrated manner are of fundamental importance, such as early diagnosis with high sensitivity of humans and infected dogs, effective treatment and the use of vaccines. Traditional diagnosis of VL is based on the presence of anti-Leishmania antibodies and the gold standard is the visualization of amastigote forms of the parasite in biological samples. However, the introduction of vaccination of dogs in recent years creates the need for new serological methods able to differentiate between vaccinated and infected animals. The objective of this study was to evaluate the metallo-peptidase zinc dependent Clan ME, M16 Family, secreted from $L$. infantum, as a marker for serological diagnosis of VL. In silico analysis revealed that the protein had $47.35 \%$ of amino acid residues exposed to the solvent, exhibiting on your surface areas for possible B cell epitopes, glycosylation and phosphorylation sites. The expression of proteins in different systems allowed to assess the immunogenicity of the heterologous proteins, with and without post-translational modifications, against sera from infected and healthy dogs. The results of the ELISA assay showed high levels of specific antibodies against heterologous proteins and the comparison of the results shows that heterologous protein expressed in a prokaryotic model was able to differentiate all infected animals at dilutions 1:50 and 1: 100 serum. Statistical analysis emphasize the potential of this protein to be used in diagnosis for VL. The study presents relevant information on the use of metallo-peptidase studied so it can be associated with the improvement of the diagnosis of VL. Tests to define the sensitivity and specificity are made necessary in future work.

Keywords: Leishmania, leishmaniasis, metallo-peptidase, heterologous protein, diagnosis. 


\section{LISTA DE FIGURAS}

Figura 1: $\quad$ Sinais clínicos da leishmaniose................................................. 4

Figura 2: Áreas endêmicas da leishmaniose cutânea no mundo................. 5

Figura 3: Áreas endêmicas da leishmaniose visceral no mundo................... 7

Figura 4: $\quad$ Agente etiológico da leishmaniose........................................ 8

Figura 5: Classificação das espécies de Leishmania conforme seu padrão de desenvolvimento no hospedeiro invertebrado......................... 9

Figura 6: Ciclo de vida da Leishmania no homem................................... 11

Figura 7: Estrutura da MPP da subunidade alfa do Clã ME, família M16, subfamília M16B de Homo sapiens........................................... 18

Figura 8: Sequências proteica e nucleotídica da MPP.............................. 36

Figura 9: Alinhamento múltiplo entre tripanosomatídeos............................. 38

Figura 10: Análise da estrutura físico-química da proteína pela ferramenta

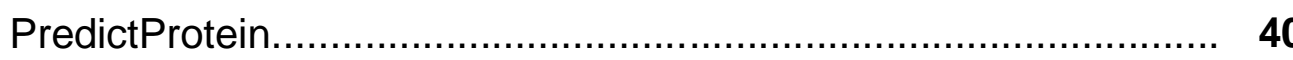

Figura 11: Correlação dos dados do PredictProtein com BepiPred................ 43

Figura 12: Predição de sítios de fosforilação com a ferramenta NetPhos v2.0.

Figura 13: Predição de sítios de glicosilação com as ferramentas GlycoEP e YinOYang v1.2.

Figura 14: Correlação dos dados preditos em L. infantum $x$ sequências de outros tripanosomatídeos.

Figura 15: Padronização das PCRs usando os primers LC01/02...

Figura 16: Análise da presença do gene LDBPK_130760 no DNA plasmidial extraído

Figura 17: Análise do sequenciamento dos clones.

Figura 18: Verificação da presença do gene LDBPK_130760 no vetor de expressão após transformação

Figura 19: Análise da expressão da rMPP em sistema procarioto em escala de tempo por indução de IPTG no meio de cultura e análise de solubilidade após sonicação.

Figura 20: Etapas da purificação da rMPP de sistema procarioto.

Figura 21: Detecção da rMPP por Western blotting com anticorpo anti calda de histidina da rMPP de sistema procarioto. 
Figura 22: Análise molecular por PCR da presença do gene

LDBPK_130760 em L. tarentolae transfectada.......................... 56

Figura 23: Etapas da purificação da rMPP de sistema eucarioto dos extratos solúvel e insolúvel....................................................................... 56

Figura 24: Detecção da rMPP por Western blotting com anticorpo anti calda de histidina da rMPP de sistema eucarioto.................................. 57

Figura 25: Avaliação de antigenicidade da proteína XP_001464106.1 dos sistemas procarioto e eucarioto por ELISA 


\section{LISTA DE TABELAS}

Tabela 1: Primers utilizados nos ensaios moleculares por PCR ............... 23

Tabela 2: Predição de epitopos lineares para células B ............................ 41 


\begin{tabular}{|c|c|}
\hline${ }^{\circ} \mathrm{C}$ & Grau célsius \\
\hline$\mu \mathrm{g}$ & Micrograma \\
\hline$\mu \mathrm{L}$ & Microlitro \\
\hline BLAST & Basic Local Alignment Search Tool \\
\hline BLASTn & Basic Local Alignment Search Tool, nucleotide query \\
\hline $\mathrm{C}_{6} \mathrm{H}_{8} \mathrm{O}_{7}$ & Ácido cítrico \\
\hline $\mathrm{CaCl}_{2}$ & Cloreto de cálcio \\
\hline CDC & Centers for Disease Control and Prevention \\
\hline CEUA & Comitê de Ética no Uso de Animais \\
\hline D.O. & Densidade óptica \\
\hline DNA & Ácido desoxirribonucleico \\
\hline EDTA & EtilenoDiaminoTetraAcético \\
\hline ELISA & $\begin{array}{l}\text { Enzyme Linked Immunosorbent Assay - Ensaio de } \\
\text { Imunoabsorbância enzimática }\end{array}$ \\
\hline $\mathbf{g}$ & 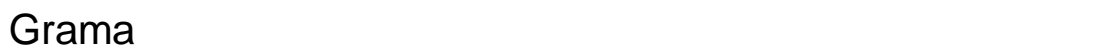 \\
\hline & Força gravitacional \\
\hline $\mathrm{H}_{2} \mathrm{SO}_{4}$ & Ácido sulfúrico \\
\hline $\mathrm{HCl}$ & Ácido clorídrico \\
\hline $\lg$ & Imunoglobulina \\
\hline IgG & Imunoglobulina G \\
\hline IPTG & Isopropyl $\beta$-D-1-thiogalactopyranoside \\
\hline LB & Luria Broth \\
\hline $\mathbf{M}$ & Molar \\
\hline mg & Miligrama \\
\hline $\mathbf{m L}$ & Mililitro \\
\hline $\mathbf{m M}$ & Milimolar \\
\hline mm & Milímetro \\
\hline $\mathrm{Na}_{2} \mathrm{CO}_{3}$ & Carbonato de sódio \\
\hline $\mathrm{NaHCO}_{3}$ & Bicarbonato de sódio \\
\hline $\mathrm{NaH}_{2} \mathrm{PO}_{4}$ & Fosfato monosódico \\
\hline $\mathrm{Na}_{2} \mathrm{HPO}_{4}$ & Fosfato de sódio dibásico \\
\hline $\mathrm{NaCl}$ & Cloreto de sódio \\
\hline NCBI & National Center for Biotechnology Information \\
\hline nm & Nanômetro \\
\hline OPD & o-Phenylenediamine \\
\hline pb & Pares de bases \\
\hline PBS & Tampão fosfato salino \\
\hline PCR & $\begin{array}{l}\text { Polymerase Chain Reaction - Reação em cadeia da } \\
\text { Polimerase }\end{array}$ \\
\hline pH & Potêncial hidrogeniônico \\
\hline rpm & Rotações por minuto \\
\hline SDS & Dodecil sulfato de sódio \\
\hline SDS-PAGE & Sodium dodecyl sulfate polyacrylamide gel electrophoresis \\
\hline SSC & Tampão salino citrato de sódio \\
\hline TAE & Tris ácido acético EDTA \\
\hline X-Gal & 5-bromo-4-chloro-3-indolyl--D-galactoside \\
\hline
\end{tabular}


World Health Organization - Organização Mundial da Saúde 


\section{SUMÁRIO}

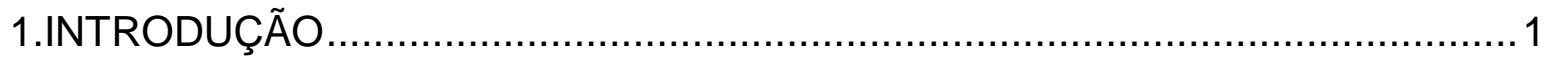

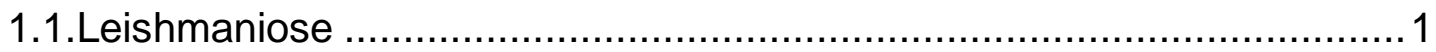

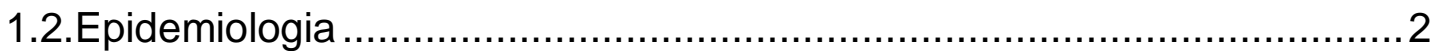

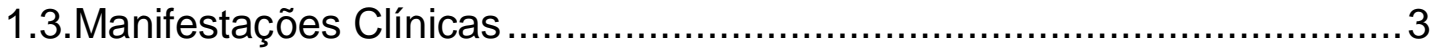

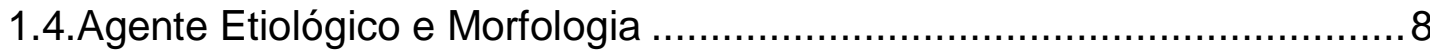

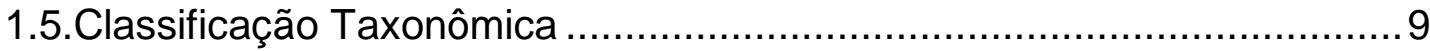

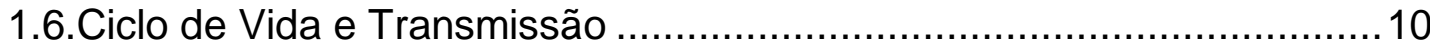

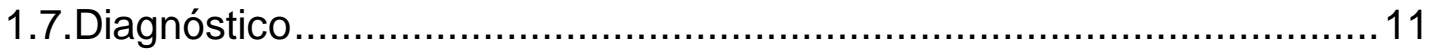

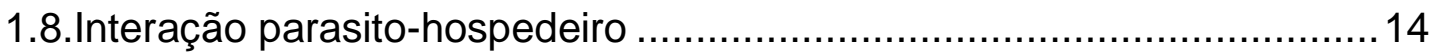

1.9.Proteases secretadas de Leishmania ................................................... 16

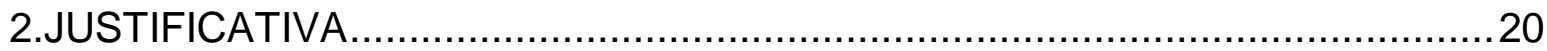

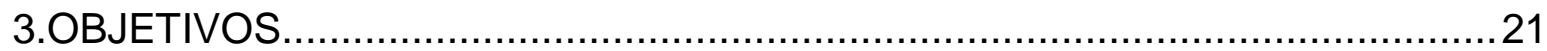

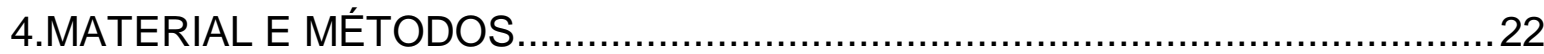

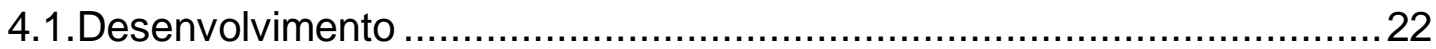

4.2.Predição da estrutura primária, sítios de fosforilação, glicosilação e de

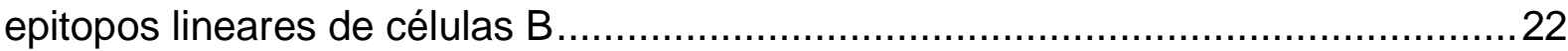

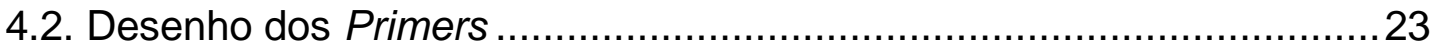

4.3.Reação de polimerização em cadeia (PCR) ………………………....23

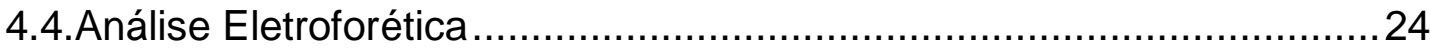

4.5.Clonagem dos Produtos de PCR e dos Produtos de Digestão Plasmidial

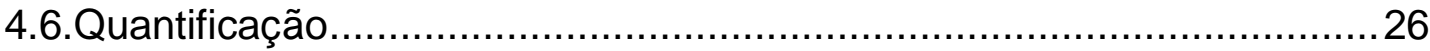

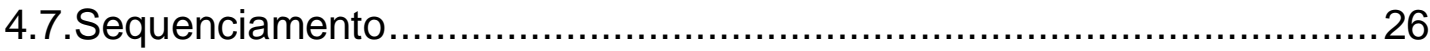

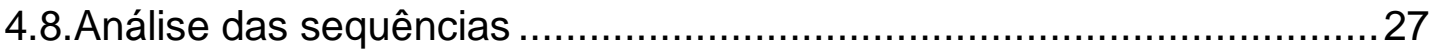

4.9.Expressão das proteínas em modelo procariótico …………………....27 
4.10. Expressão de proteínas em modelo eucariótico .29

4.11.Purificação da proteína recombinante dos sistemas eucarioto e procarioto por cromatografia de afinidade.

4.12. Western Blotting 32

4.13.Ensaio de Imunoabsorbância Enzimática (Enzyme Linked Immunosorbent Assay - ELISA) .33

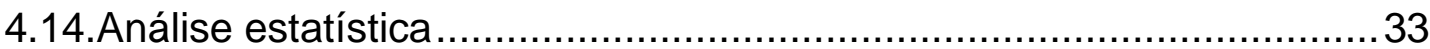

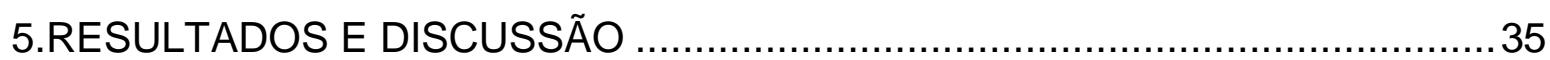

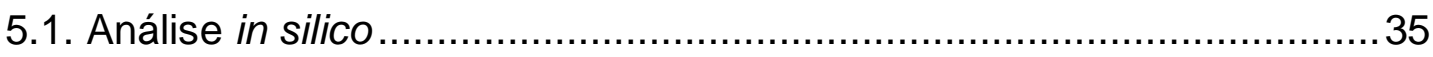

5.3. Reação de Polimerização em Cadeia (PCR) ………........................... 48

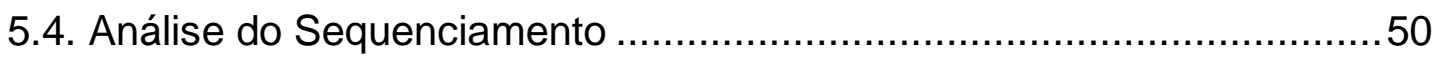

5.5. Expressão de proteína em sistema procarioto ......................................52

5.6. Expressão de proteína em modelo eucarioto.........................................55

5.7.Ensaio de Imunoabsorbância Enzimática - ELISA ………………….....57

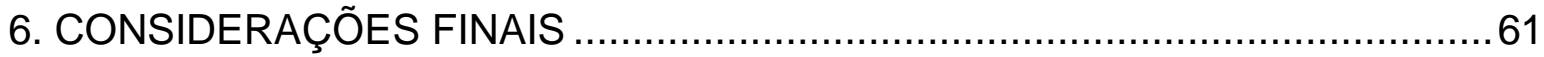

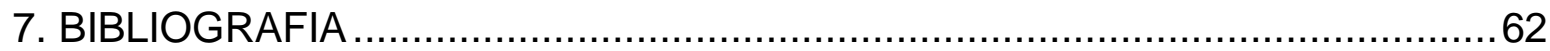

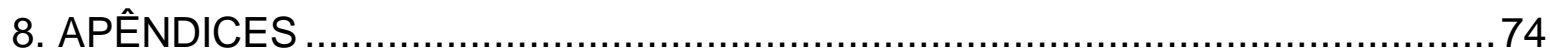

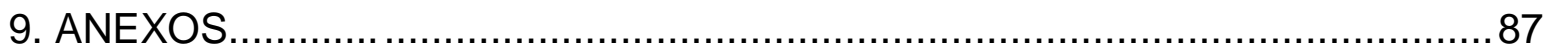




\section{INTRODUÇÃO}

\subsection{Leishmaniose}

As leishmanioses são um conjunto de doenças que acometem animais e humanos (antropozoonóticas) e causam diferentes manifestações clínicas causadas por parasitos protozoários intracelulares do gênero Leishmania. Estas doenças acometem 98 países em cinco continentes - África, Ásia, Europa e Américas principalmente nas regiões tropicais e subtropicais (Smith e Peacock, 2007; Bhargava e Singh, 2012; WHO, 2016). Estima-se que pelo menos 20 espécies de Leishmania causem doenças em humanos, sendo transmitidas por inoculação durante o repasto sanguíneo de fêmeas infectadas de insetos do gênero Lutzomyia ou Phlebotomus (Ashford, 2000; Bhargava e Singh, 2012; Junior e cols, 2014).

Um dos primeiros relatos clínicos sobre a leishmaniose data do ano de 1756, quando Alexander Russell descreveu os primeiros sinais clínicos da doença e a chamou de febre de Aleppo (Hide e cols, 2007; Dawit e cols, 2013). Os primeiros estudos relacionados com o parasito datam do final do século XIX com a publicação feita em 1885 por Cunningham sobre a morfologia de estranhos corpos encontrados em órgãos linfoides (Writh,1904) formas descritas hoje como amastigotas. Na virada do século XIX, muitos pesquisadores, de maneira independente, estavam envolvidos na pesquisa do parasito que causa a leishmaniose (WHO 2010).

No ano de 1900, William Leishman encontrou o parasito em material de necropsia de esfregaço do baço de um soldado que faleceu na Inglaterra de febre Dum-Dum contraída em Calcutá e considerou-o uma forma evolutiva de tripanossomatídeo, relatando sua descoberta em 1903 (Leishman, 1903; Pai-Dhungat e Parikh, 2015). No mesmo ano, Charles Donovan relatou um organismo semelhante encontrado em punção de baço de um menino indiano com Kala-azar em Madras. Com isso, Leishman dividiu a descoberta com Donovan e essas formas parasitárias ficaram conhecidas como corpúsculos Leishman-Donovan (Pai-Dhungat e Parikh, 2015). Ronald Ross sugeriu no mesmo ano a alteração do nome dado a esses organismos por Laveran e Mesnil, em 1903, de Piroplasma donovani para Leishmania donovani por pertencerem a um novo gênero (Ross, 1903; Pai-Dhungat e Parikh, 2015). 
Rogers mostrou que as formas flageladas se desenvolviam em culturas, e Adler e Ber demonstraram que formas promastigotas de Leishmania major desenvolviam-se em flebotomíneos do gênero Phlebotomus e que a picada do inseto transmitia a doença ao homem (Rogers, 1904 Adler e Ber 1941).

\subsection{Epidemiologia}

As leishmanioses são doenças negligenciadas que acometem principalmente regiões tropicais e possuem diferentes formas clinicas, sendo classificadas de modo geral como: leishmaniose visceral (LV), comumente referida como Calazar, e leishmaniose tegumentar (LT). Estas doenças causam problemas na saúde humana em escala global com uma estimativa de 350 milhões de indivíduos em risco de contrair leishmanioses e com aproximadamente 20 milhões de pessoas infectadas no mundo. São estimados 1,3 milhões de novos casos a cada ano, dos quais 1 milhão da forma tegumentar e 0,3 milhões da forma visceral da doença com um índice de mortalidade entre 20.000 e 40.000 mortes por ano. (Wijeyaratne e cols, 1994; Bhargava e Singh, 2012; Duthie e cols, 2012; WHO, 2016).

No Brasil, a LV e LT inicialmente tinham um caráter eminentemente rural, contudo, vieram se expandindo para as áreas urbanas de médio e grande porte (MDS, 2007;2014). Alguns fatores de risco para o aumento de casos podem ser provocados pelo ser humano como, por exemplo, migração, deflorestação, urbanização ou por mudanças na suscetibilidade do hospedeiro a infecção que podem ocorrer em casos de imunodepressão e subnutrição. Contudo, outros fatores estão associados a mudanças ambientais sem interferência do ser humano, estas alterações incluem mudanças na temperatura, precipitação e umidade que podem ter fortes efeitos sobre vetores e reservatórios, alterando sua distribuição, sobrevivência e o tamanho da população (Ashford, 2000; WHO 2016). Variações de origem natural podem ainda ter efeito sobre o ciclo de desenvolvimento de formas promastigota de Leishmania em flebotomíneos, as quais permitiriam a transmissão do parasito em áreas anteriormente não endêmicas para a doença (Ashford, 2000).

Segundo o Ministério da Saúde (MDS), o número de casos registrados de LT no Brasil, entre os anos 1985-2005, apontaram uma média anual de 25.568 casos. Os casos de LV notificados, entre os anos 1984-2002, somaram 48.455 casos. A maioria 
dos casos de leishmaniose foram oriundos das regiões Norte e Nordeste do país (MDS, 2007;2014).

No Distrito Federal (DF) há evidências de transmissão autóctone de LT desde 1980, quando o primeiro caso em criança de 2 anos foi relatado. De acordo com os dados do Ministério da Saúde, o número de casos de LT notificados, entre os anos de 2004-2014, somaram 397 casos humanos (MDS, 2016a). Os casos relatados de LV, durante os anos de 2004-2014, apontaram 68 casos em humanos e cerca de 590 casos positivos em cães notificados no ano de 2013 (Herenio e cols, 2014; MDS, 2016b).

\subsection{Manifestações Clínicas}

\subsubsection{Leishmaniose Tegumentar (LT)}

A LT, também conhecida como leishmaniose dermotrópica/mucotrópica, caracteriza-se por afetar principalmente a estrutura da pele e, excepcionalmente, das mucosas das vias aéreas superiores, sendo reconhecidas clinicamente: a leishmaniose cutânea localizada (LC), da qual pode evoluir para leishmaniose cutânea disseminada (LCLD), leishmaniose cutânea difusa (LCD) e leishmaniose mucosa (LM) (Altamirano-Enciso e cols 2003; Desjeux, 2004; Hashiguchi e cols, 2016).

\subsubsection{Leishmaniose Cutâneo Localizada (LC)}

A LC (Figura 1A), também conhecida como botão do oriente, manifesta-se normalmente nas regiões da face, braços, mãos e pernas por serem áreas expostas e acessíveis ao flebotomineo. As leishmanias multiplicam-se nos macrófagos dermais próximos a área da picada feita pelo flebotomíneo, a lesão aparece inicialmente como uma persistência da picada do inseto e gradualmente aumentam o tamanho, tomando uma coloração avermelhada, mas sem dor ou calor notáveis na mesma (Ashford, 2000; Davidson, 2005; Neuber, 2008; Bhargava e Singh, 2010). A resolução da lesão envolve a imigração de leucócitos, os quais isolam a área infectada, levando à necrose dos tecidos parasitados e a formação de um granuloma de cicatrização na superfície da lesão, assemelhando a um botão (Ashford, 2000; Bhargava e Singh, 2012). O tamanho da lesão e sua extensão e padrão variam de acordo com a espécies do parasito, de fatores genéticos do hospedeiro e da extensão da resposta imune. A cura espontânea da LC pode variar de 6-12 meses com sequelas resultantes do processo 
imunológico que variam desde cicatrizes até a desfiguração da área (Neuber, 2008; Pace, 2014).
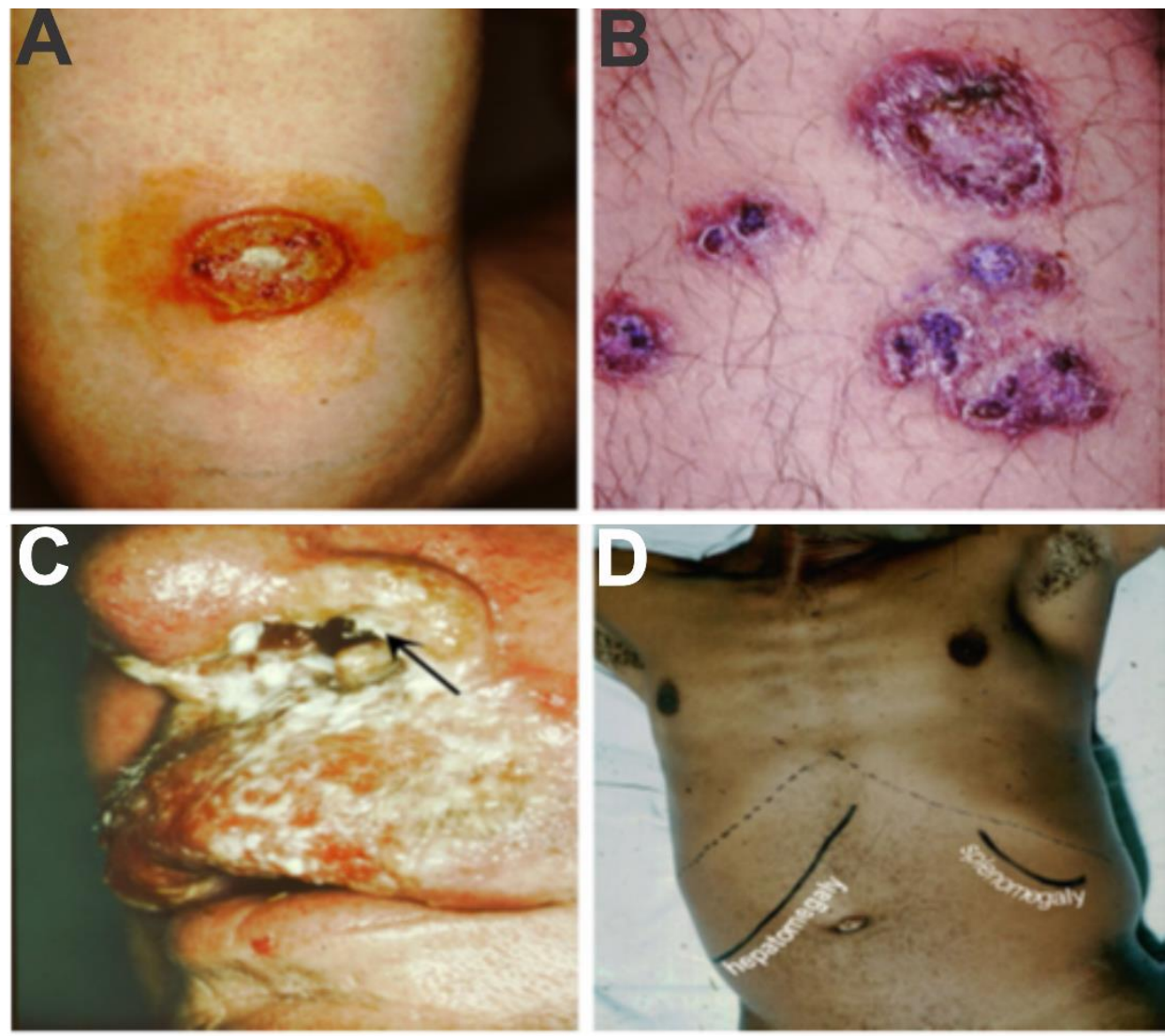

Figura 1: Sinais clínicos da leishmaniose. A Lesão característica de LC. B Lesões características de LCD. C Lesão características der LM (evidenciada pela seta). D LV, sinais de hepatoespenomegalia. Fonte: Adaptado de Bifeld e Clos, 2015.

Esse tipo de leishmaniose é causado comumente pelas espécies Leishmania tropica, L. major, L. aethiopica, L. mexicana, L. amazonensis, L. panamensis, $L$. guyanensis, L. peruviana e L. braziliensis, mas podem ser causadas por outras espécies de Leishmania que infectem humanos, sendo esta encontrada em vários países do mundo (Figura 2) (Bhargava e Singh, 2012). 


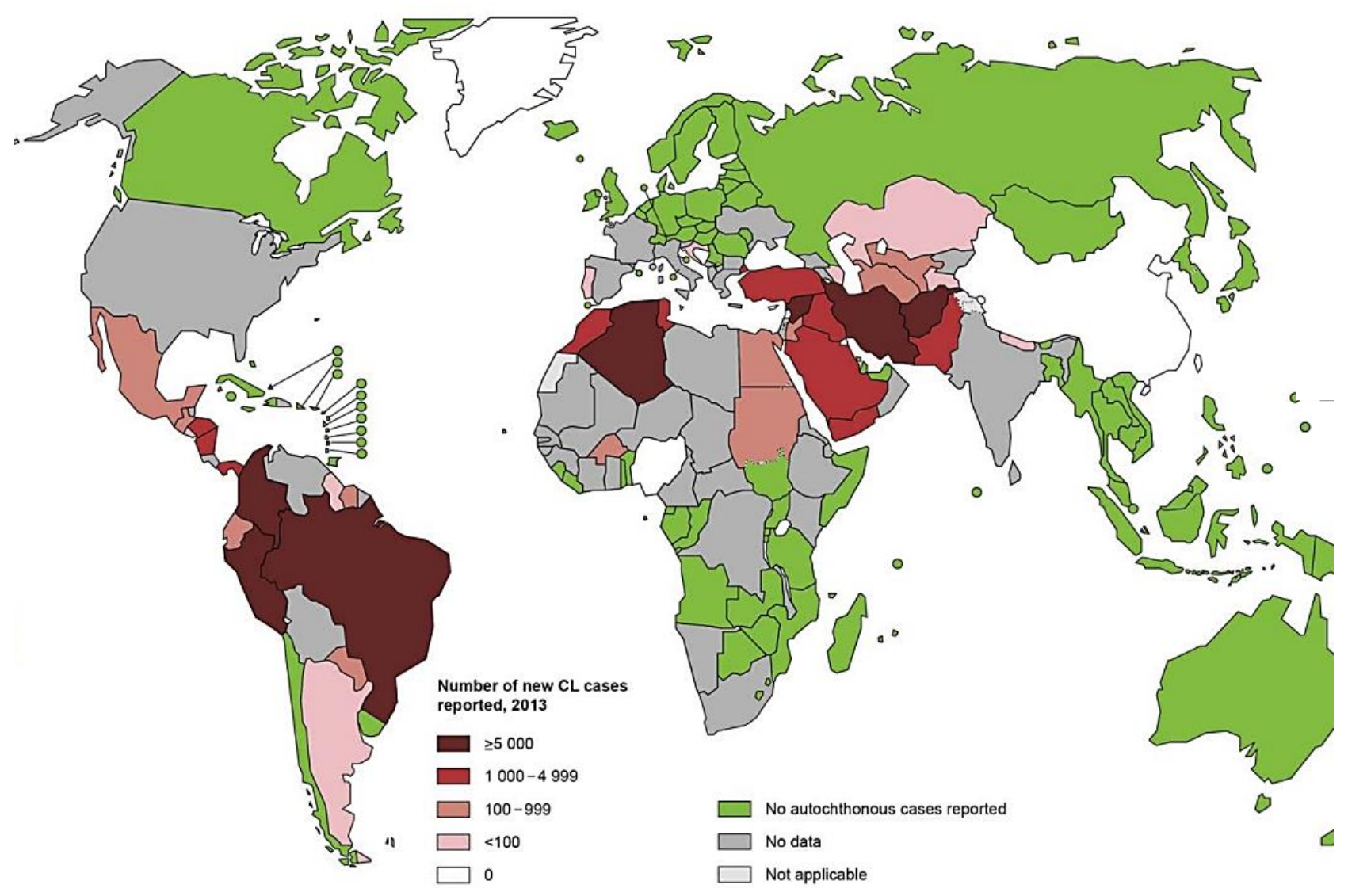

Figura 2: Áreas endêmicas da leishmaniose cutânea no mundo. A Organização Mundial da Saúde aponta países como zonas endêmicas de LC, com numerosos casos reportados. Adaptado de WHO, 2016

\subsubsection{Leishmaniose Mucosa (LM)}

A LM ocorre, na maioria dos casos, após a lesão inicial da forma LC, onde as formas parasitárias de Leishmania encontradas nas lesões cutâneas podem ser disseminadas por vias linfáticas ou sanguíneas ao longo de meses ou anos após a aparente resolução da lesão inicial para regiões muco-cutâneas do corpo (Figura 1C), comumente mucosas oronasais ou faríngeas (Ebrahm, 2000; Davidson, 2005; Fsadni e cols, 2007; Goto e Lindoso, 2010; Pace, 2014). A doença espalha-se, ao longo dos anos, de forma imprevisível para regiões da nasofaringe, palato, úvula, laringe e vias aéreas superiores e sua manifestação comprometem a função das áreas afetadas. Ao contrário da LC, as lesões decorridas da LM não se curam espontaneamente e geram mutilação dos tecidos ou sua destruição (Goto e Lindoso, 2010; Pace, 2014). Esta 
enfermidade esta correlacionada às formas parasitárias pertencentes ao complexo Leishmania braziliensis.

\subsubsection{Leishmaniose Cutâneo-Disseminada (LCLD) Bordeline}

A leishmaniose cutâneo-disseminada bordeline foi clinicamente descrita por Silveira (2004) a qual caracterizou sua patogenicidade em dois extremos, um polo de hipersensibilidade e um polo de hiposensibilidade. A doença é considerada uma forma indeterminada entre LC e LCD, possuindo um processo de disseminação rápido, que em poucos meses, uma centena de pápulas (lesões acneiformes) e/ou lesões cutâneas ulceradas podem ocorrer, essas lesões são dependentes das espécies que as causam (Silveira, 2004; Hashiguchi e cols, 2016).

\subsubsection{Leishmaniose Cutâneo Difusa (LCD)}

A LCD é manifestada, geralmente, através da ação de parasitos que normalmente causam a LC, formas amastigotas que persistem no tecido por anos, que podem estar associados à anergia ou falta de resposta imunológica (Ashford, 2000). As lesões afetam somente a pele, iniciando-se como uma pápula não ulcerativa no local da inoculação (Figura 1B), entretanto, surgindo outras lesões semelhantes decorrentes da disseminação via sanguínea (Alrajhi 2003, WHO, 2016). É causada principalmente pela $L$. aethiopica na África e $L$. amazonensis na América do Sul e Central (Davidson, 2005). A leishmaniose dermal pós-calazar é uma forma de LCD que surge como sequela da leishmaniose visceral e que pode ocorrer após anos em indivíduos não-tratados, parcialmente tratados e em indivíduos considerados adequadamente tratados. (Rathi e cols, 2005, WHO, 2016).

\subsubsection{Leishmaniose Visceral (LV)}

A LV é comumente conhecida como calazar, nome derivado de kala-azar, oriundo da India, é a forma mais severa das leishmanioses sendo uma doença conhecida pelo viscerotropismo do parasito ao fígado (Figura 1D), baço e medula óssea (Chappuis e cols, 2007; Clem, 2010). Na maioria dos casos, cerca de $90 \%$, os indivíduos infectados são oriundos ou vivem em países endêmicos, como: Índia (especialmente Bihar), Bangladesh, Nepal, Brasil (norte e nordeste) e Sudão (WHO, 2016) (Figura 3). No Brasil, a VL está presente nas cinco regiões, em 21 estados. 
Dados do Ministério da Saúde reportam aproximadamente 2 a 3 mil novos casos por ano (Madalosso e cols, 2012).

A LV é causada, principalmente, pelas espécies de Leishmania donovani na índia e na África, pela Leishmania infantum (sinônimo de L. chagası) no Mediterrâneo, na China, na Europa, África (Norte), no continente americano, principalmente, no Brasil (Figura 3) (Pereira e cols, 2013; Silva Junior e cols, 2014, Das e cols, 2015). Contudo, algumas espécies de Leishmania responsáveis por causar leishmaniose visceral podem, também, causar LC. A LV é uma enfermidade crônica caracterizada pelos sintomas de febre, anemia, anorexia, deficiência de elementos celulares do sangue e hepatoesplenomegalia (Figura 2D) que, se não tratada adequadamente após o surgimento dos primeiros sintomas, pode levar o indivíduo ao óbito (Dayakar e cols, 2011; Silva Junior e cols, 2014).

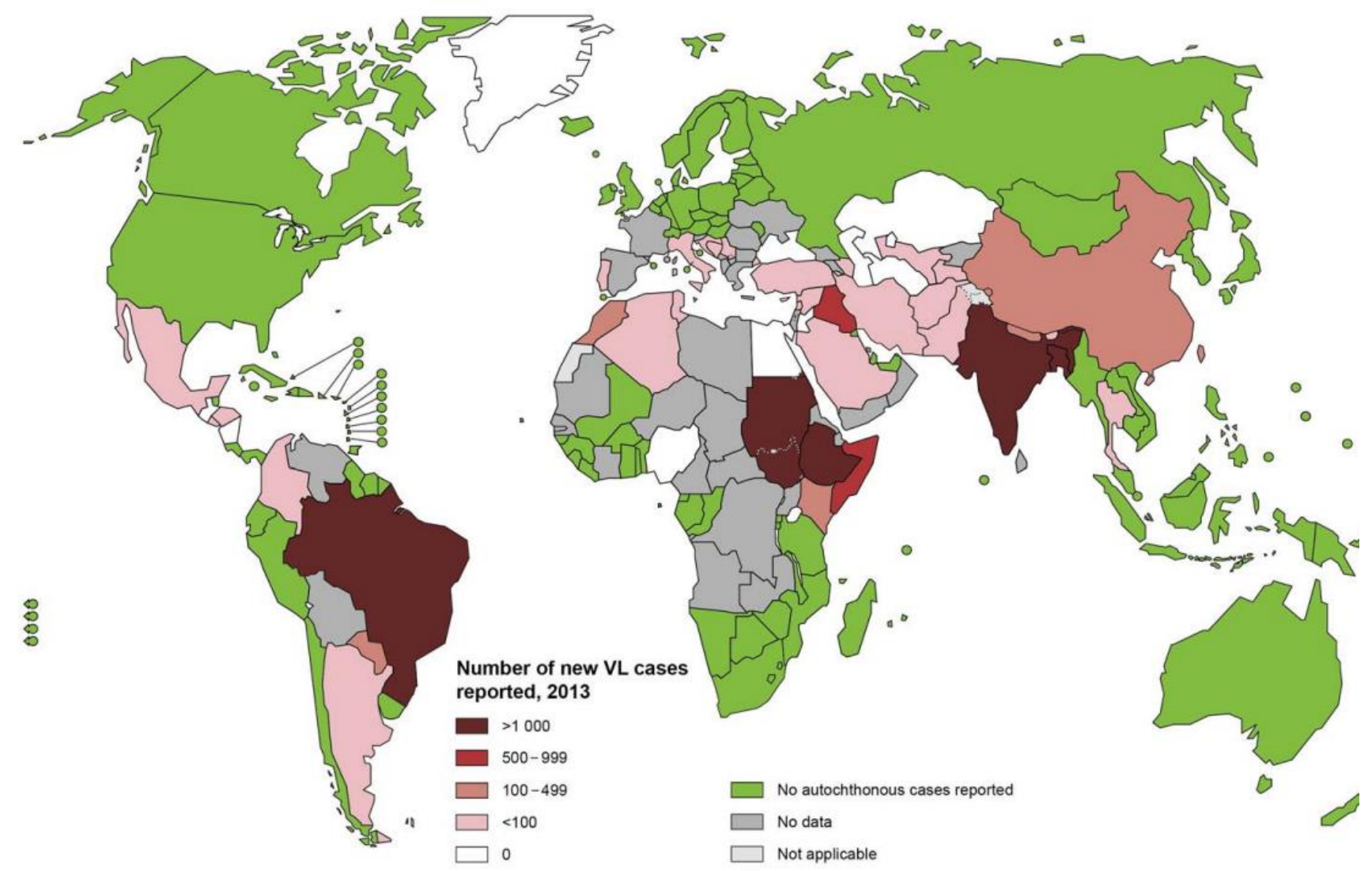

Figura 3: Áreas endêmicas da leishmaniose visceral no mundo. Dados da Organização Mundial de Saúde apontam o Brasil, Etiópia, Sudão, Índia e Bangladesh como países endêmicos de LV, com casos reportados sendo superiores ou iguais a 1000. Adaptado de WHO (2016).

Este tipo de doença está emergindo como uma importante infecção oportunista entre os indivíduos com infecção pelo HIV. Como esperado, o parasito não se 
comporta de uma forma clássica em hospedeiros imunossuprimidos, e a doença pode ocorrer em locais incomuns como intestino, pulmões e sistema nervoso central (Ebrahm, 2000; WHO, 2016).

\subsection{Agente Etiológico e Morfologia}

Os parasitos do gênero de Leishmania são pertencentes ao reino Protista, subreino Protozoa, filo Sarcomastigophora, sub-filo Mastigophora, classe Zoomastigophora, ordem Kinetoplastida, família Trypanosomatidae, sessão Salivaria, gênero Leishmania e, ainda, são divididos em dois subgêneros: Leishmania e Viannia (Lee, 2000; Lainson, 2010). Os parasitos que compõe o gênero Leishmania são similares morfologicamente apresentando formas amastigotas (flagelo não exteriorizado) e promastigota (flagelo exteriorizado) (Sehgal e cols, 2012). A forma promastigota é alongada com aparência fusiforme, mede de 12 a $20 \mu \mathrm{m}$ e apresenta um flagelo livre e longo, emergindo do corpo do parasito na sua porção anterior. Esta forma desenvolve-se no interior do intestino do inseto vetor e é encontrada em diferentes formas de diferenciação (desenvolvimento) até atingir a forma infectante, conhecida como promastigota metacíclico (Waller e Mcconville, 2002; Ferreira, 2012; Dawit e cols, 2012). A outra forma é conhecida como amastigota e caracteriza-se pelo aspecto oval ou esférico à microscopia óptica, mede cerca de 4 a $6 \mu \mathrm{m}$ e comportase como parasito intracelular obrigatório de fagócitos do hospedeiro vertebrado (Waller e Mcconville, 2002; Zappacosta e cols, 2010; Sehgal e cols, 2012).

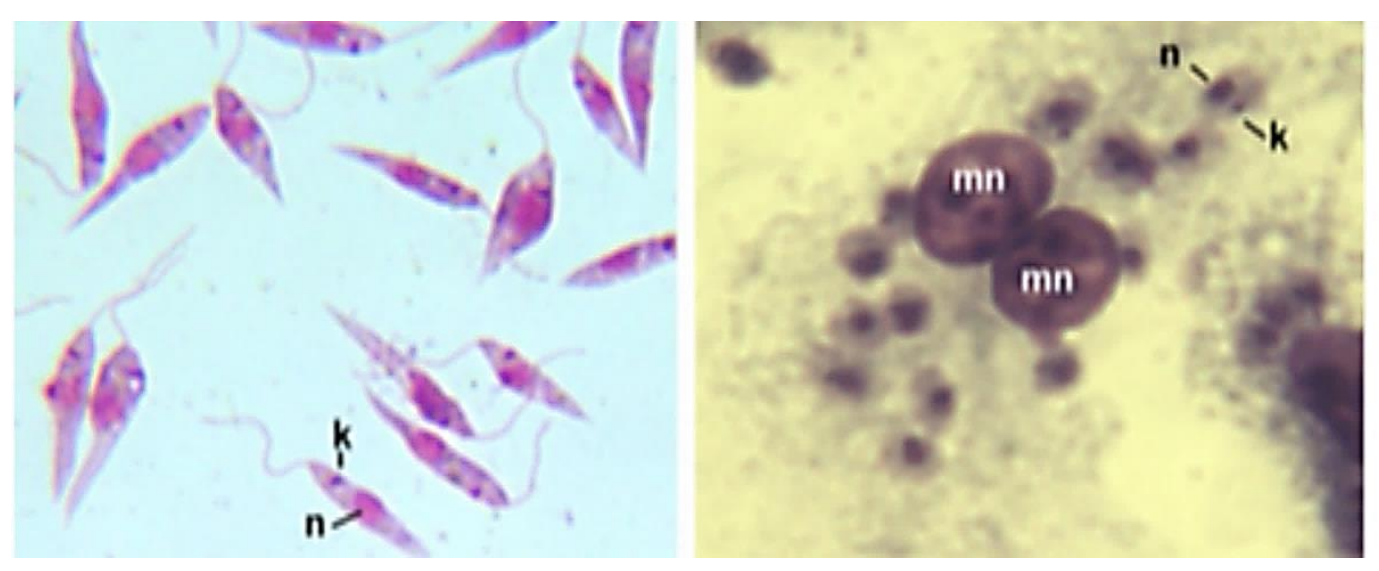

Figura 4: Agente etiológico da leishmaniose. A Formas promastigotas de Leishmania sp corados com Giemsa e observados com objetiva de 100X, destacando $\mathrm{k}=$ cinetoplasto. B Macrófagos oriundos de modelo murino infectados por $L$. major. $\mathrm{k}=$ cinetoplasto e $\mathrm{n}=$ núcleo do parasito. Adaptado de Bifeld e Clos (2015). 


\subsection{Classificação Taxonômica}

Vários sistemas de classificações foram usados entre os anos de 1916 e 1987 para classificar o gênero Leishmania. Estes sistemas culminaram na divisão do gênero Leishmania em dois subgêneros: Leishmania, presente no Velho e Novo Mundo, e Viannia, restrito ao Novo Mundo (Lainson, 2010). A classificação das espécies de Leishmania nos subgêneros foi realizada de acordo com o desenvolvimento do parasito no sistema digestório do hospedeiro invertebrado durante seu ciclo de vida (Figura 5). O subgênero Leishmania (Leishamania) compreende os parasitos que tem seu ciclo de vida limitada ao intestino médio e intestino anterior (desenvolvimento suprapilariano) do inseto hospedeiro (Ross, 1903, Laison, 2014). O subgênero Viannia é caraterizado pelos parasitos que tem seu desenvolvimento tanto na região do intestino médio e do intestino posterior (desenvolvimento peripilariano) (Lainson, 2010; WHO, 2010).

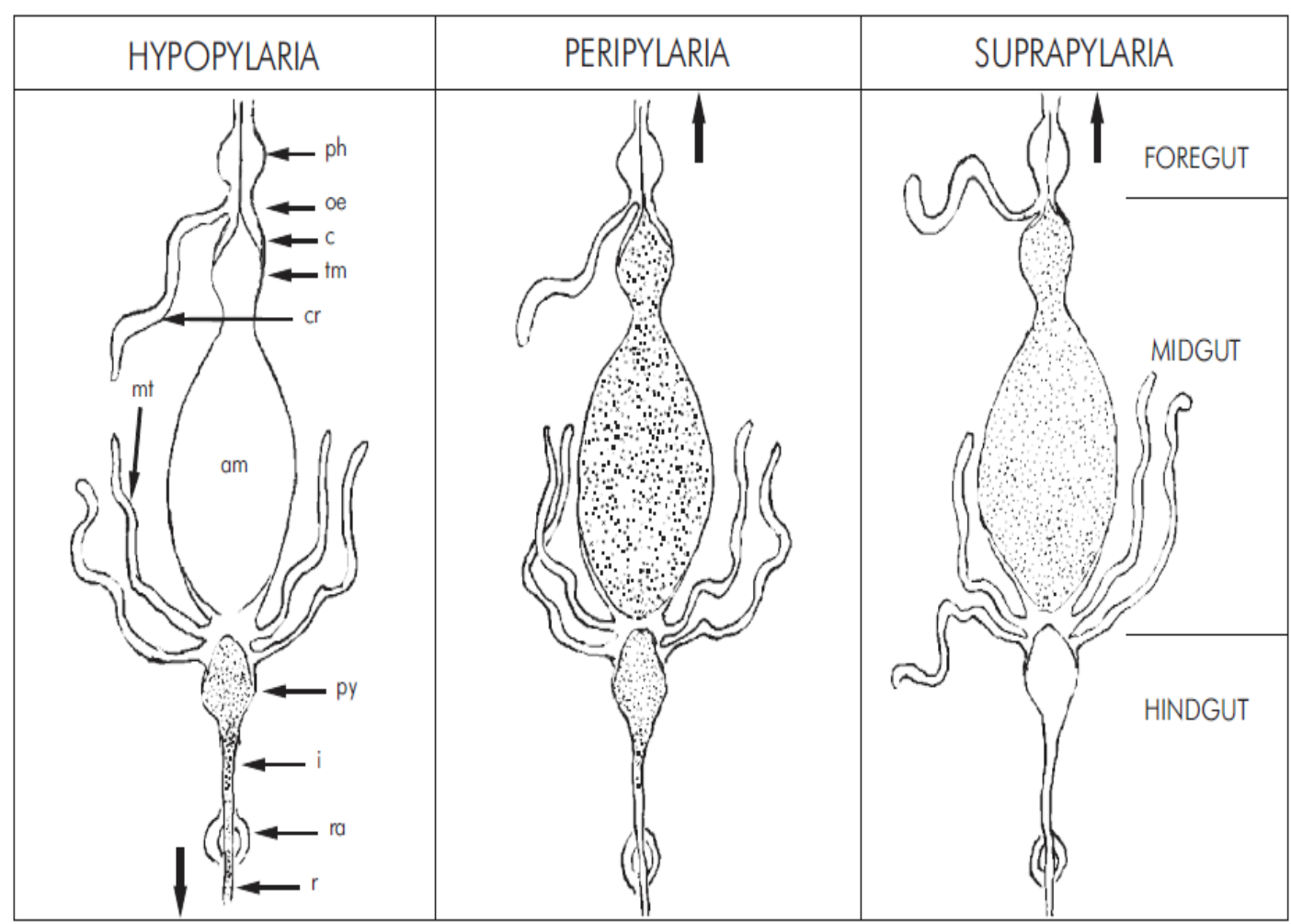

Figura 5: Classificação das espécies de Leishmania conforme seu padrão de desenvolvimento no hospedeiro invertebrado.

Seção HIPOPILARIANO: O desenvolvimento destes parasitos, encontrados apenas em lagartos do Velho Mundo, é restrita ao intestino posterior do inseto vetor. Transmissão via ingestão de insetos infectados por lagartos.

Seção PERIPILARIANO: Desenvolvimento do intestino posterior é mantido, mas parasitos também migram para o intestino médio. A transmissão ocorre pela picada inseto vetor infectado. Encontrado em alguns lagartos do Velho Mundo. Também inclui espécies de parasitos Leishmania dentro do subgênero Viannia, que são restritos aos mamíferos do Novo Mundo. 
Seção SUPRAPILARIANO: O desenvolvimento do parasito é restrito ao intestino médio e intestino anterior. A transmissão ocorre pela picada do inseto vetor infectado. Encontrado em mamíferos tanto do Velho Mundo e do Novo Mundo.

Fonte: Adaptado de Laison 2014.

O ponto de partida para a atual classificação ocorreu no inicio de 1970 com o desenvolvimento da eletroforese de isoenzimas, a qual décadas mais tarde tornou-se padrão ouro para identificação e ainda permanece como uma técnica de referência para caracterização de parasitos (Akhoundi e cols, 2016). Entretanto, a variação enzimática de um determinado locus pode ser interpretada como uma mutação que ocorreu durante a evolução do parasito. Subsequentemente, as classificações filogenéticas revelaram relações parentais entre as diferentes espécies de Leishmania, tal como foi confirmado pelo uso de vários marcadores moleculares (Lainson, 2010; Akhoundi e cols, 2016).

Em conclusão, os dados moleculares não condizem com o conceito de complexos de espécies estabelecidos por Laison e Shaw, sugerindo que a classificação seja revista. O continuo sequenciamento de genomas de Leishmanias e a análise de SNP (polimorfismo de nucleotídeo único), bem como análises mais profundas por tipagem de mutilocus por micro-satélites poderão contribuir para uma melhor classifificação do gênero Leishmania (Akhoundi e cols, 2016).

\subsection{Ciclo de Vida e Transmissão}

As leishmanias apresentam um ciclo de vida complexo, envolvendo passagem entre hospedeiro invertebrado e vertebrado (Bañuls e cols, 2007). O ciclo de vida inicia-se quando a fêmea do inseto-vetor parasitada realiza o repasto sanguíneo em um hospedeiro mamífero injetando formas infectantes do parasito (Figura 6) estas formas parasitárias não realizam divisão binária e são denominadas de promastigotas metacíclicas (Gossage e cols, 2003). As formas infectantes são fagocitadas rapidamente por vários tipos de células como, por exemplo, neutrófilos, macrófagos residentes nos tecidos, células dendríticas ou outras células mononucleadas. Dentro da célula hospedeira, os parasitos realizam uma mudança de forma de promastigota metacíclico para amastigota (Sehgal e cols, 2012). Esses amastigotas replicam-se dentro das células hospedeiras e, após sucessivas replicações, as células 
hospedeiras são rompidas liberando as formas amastigotas, permitindo a reinfecção dos fagócitos. O ciclo se completa quando fagócitos infectados são ingeridos por outro flebotomíneo durante repasto o sanguíneo e, em seguida, as formas amastigotas convertem-se em promastigotas no intestino médio do hospedeiro invertebrado (Waller e Mcconville, 2002; Sehgal e cols, 2012).

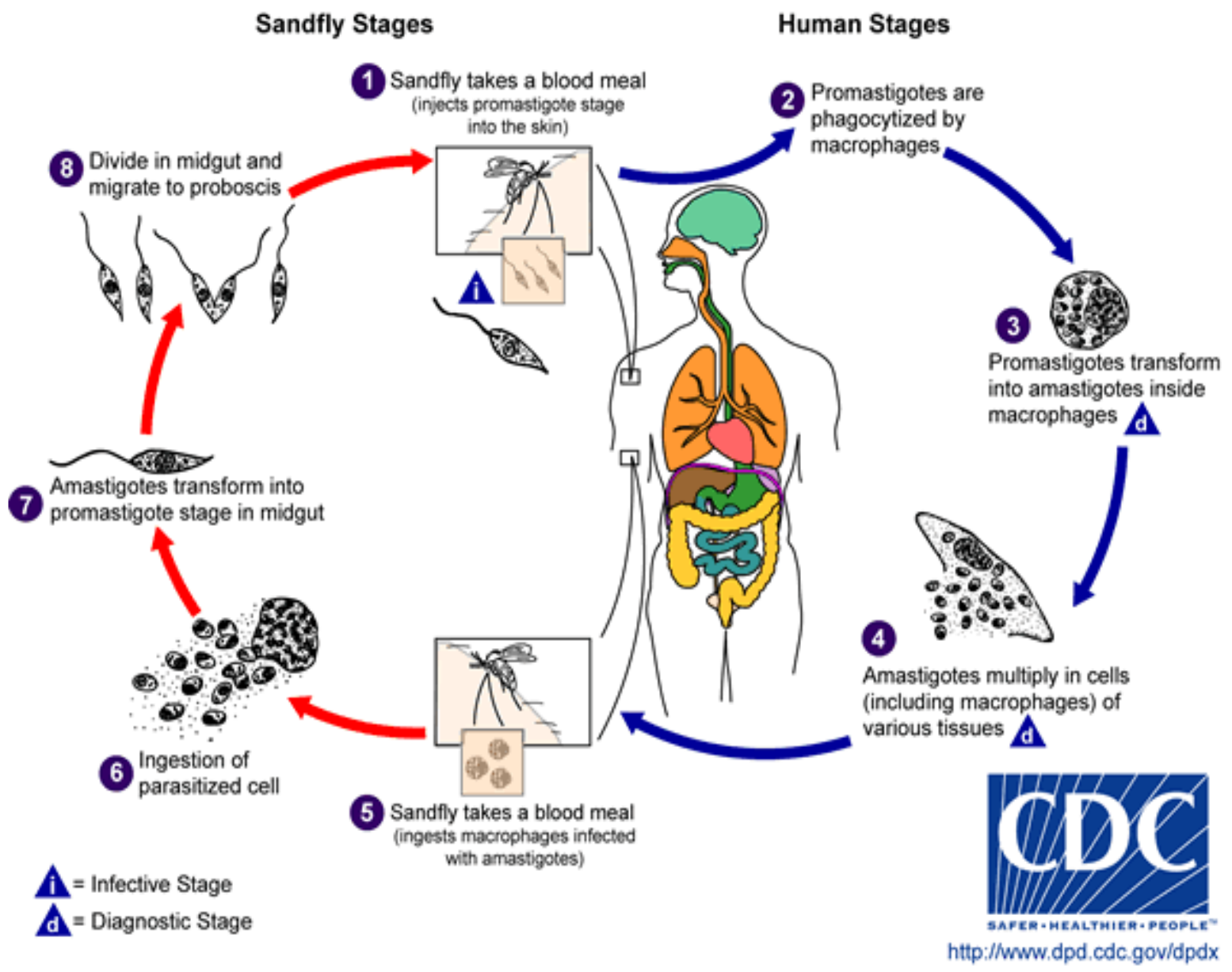

Figura 6: Ciclo de vida da Leishmania no homem. Fonte: Foto retirada de CDC, 2016.

\subsection{Diagnóstico}

A complexidade e a variedade de sintomas da leishmaniose juntamente com a presença de indivíduos assintomáticos requerem um diagnóstico baseado na relação estrita dos resultados de testes laboratoriais em conjunto com dados clínicos e epidemiológicos (Grimaldi e Tesh, 1993; Boarino e cols, 2007; Goto e Lindoso, 2010; WHO, 2016). No entanto, um diagnóstico definitivo da doença exige a demonstração do parasito por meio de métodos de diagnóstico laboratorial, este pode ser realizado 
de diferentes maneiras, tais como: (I) demonstração do parasito nos tecidos de relevância por histopatologia, cultura in vitro, ou inoculação em animal experimental; (II) detecção de DNA do parasito em amostras de tecido; ou (III) imunodiagnóstico por detecção de antígeno do parasito em amostras de tecido, sangue, ou urina, por detecção de anticorpos específicos ou inespecíficos anti-Leishmania , ou por ensaio de imunidade mediada por células Leishmania-específicas (Pereira, 2013; Sakkas e cols, 2016). Entretanto, alguns métodos necessitam de condições especiais para serem realizados, os quais limitam a escolha do método em laboratórios de rotina (Sousa e cols, 2013; CDC, 2016).

1.7.1. Demostração do parasito por histopatologia, cultura in vitro e inoculação em animal experimental

A maioria dos métodos baseados na busca microscópica do agente etiológico, pela cultura do parasito ou pela inoculação em modelo animal experimental apresentam, relativamente, baixa sensibilidade e não identificam a espécie infectante (Tsukayama e cols 2013, de Ruiter e cols, 2014). A pesquisa direta do parasito e a histopatologia são considerados métodos com alta específidade, mas com baixa sensibilidade devido a distribuição não homogênea dos parasitos nos tecidos e ainda necessitam de profissionais experientes para coletar e preparar a amostra e avaliar a lâmina (Sousa e cols, 2013, Tsukayama e cols, 2013). Os métodos de inoculação em animais e cultura do parasito podem ser utilizados, porém, a inoculação em animais susceptíveis não tem valor prático no diagnóstico da doença devido ao seu tempo de positividade, que varia de 1-3 meses (MDS, 2006). Já a cultura do parasito estará sujeita a possibilidades de contaminação além das dificuldades de crescimento do parasito (MDS, 2006; Sarkari e cols, 2014).

\subsubsection{Diagnóstico molecular}

O diagnóstico molecular é realiado usando comumente o método de PCR, baseando-se na detecção do DNA do cinetoplasto (kDNA) do pasito presente em sangue periférico, fragmentos de lesões e de medula óssea, por meio do uso de primers específicos que apresentam elevadas sensibilidade e especificidade (Singh e Sundar, 2006). Porém, esse método necessita de ferramentas e reagentes específicos de alto custo para detectar determinado gene-alvo, para extração do DNA do material 
biológico, que por muitas vezes, limitam sua aplicação em laboratórios de rotina (Almeida e cols, 2013).

\subsubsection{Diagnóstico sorológico}

Métodos de diagnóstico com base na resposta imune do hospedeiro são de extrema importância para auxiliar na elaboração do diagnóstico (Sousa e cols, 2013). A facilidade da padronização dos imunoensaios, da obtenção do material biológico (soro) do paciente e a disponibilidade de kits comerciais permitem uma fácil execução das técnicas a baixos custos. O ensaio de Imunoabsorbância enzimática (do inglês enzyme-linked immunosorbent assay - ELISA) permite revelar imunocomplexos pela adição de um substrato cromógeno que reagirá com uma enzima covalentemente ligada a um anticorpo especifico, formando um produto colorido cujo grau de coloração pode ser medida por espectrofotometria (Pereira, 2013).

O ELISA é usualmente aplicado para diagnosticar leishmaniose visceral (LV), apresentando maior sensibilidade para LV comparada a leishmaniose tegumentar (LT) (Goto e Lindoso, 2010; WHO, 2016). Os antígenos usados comumente para diagnóstico de leishmaniose no ELISA são os antígenos solúveis de Leishmania (do inglês Soluble Leishmania Antigens - SLA), contudo, mesmo que as técnicas de imunodiagnóstico que utilizam SLA apresentem alta sensibilidade, há problemas em sua especificidade, tais como: não conseguir distinguir a espécie de Leishmania e, comumente, está relacionado a reações cruzadas contra outros tripanosomatideos ou resultados falso positivos em cães vacinados (Sousa e cols, 2013; de Ruiter e cols, 2014). Uma das alternativas para minimizar reações cruzadas e aumentar a sensibilidade e especifidade dos métodos de imunodiagnóstico é baseado no uso de proteínas recombinantes de Leishmania (Sousa e cols, 2013).

Proteínas recombinantes de Leishamania tornaram-se alvos disponíveis para o diagnóstico sorológico, aumentando sua sensibilidade, espercificidade e com fácil padronização. Diversas proteínas recombinantes, entre elas k39, KMPII, Peroxidoxinas, LACK, histonas nucleossomais (H2A, H2B, H3 e H4) e proteínas de choque térmico (HSP60, 70 e 83) foram testadas para diagnóstico de leishmaniose e obtiveram resultados promissores para o desenvilvimento de kits de diagnóstico (Menezes-Sousa e cols, 2015). Contudo, a escolha do antígeno alvo é crucial para evitar reações cruzadas com outros organismos que apresentem proteínas ortólogas. 
A análise in silico da proteína alvo deve ser realizada previamente objetivando verificar: I) proteínas ortólogas; II) possíveis regiões de epitopos de células B; III) possíveis modificações pós-traducionais. Depois de coletados e análisados esses dados, o antígeno alvo poderá ser testado in vitro (Carvalho e cols, 2011; MenezesSousa e cols 2015).

A análise de proteínas ortólogas podem indicar se uma proteína poderá apresentar reações cruzadas em testes sorológicos, devido a preservação de áreas com potencial antigênico que possam estimular o sistema imune ou quando feita para verificar se uma proteína do parasito possui ortologia com humanos ou cães, poderá haver a produção de clones autoreativos que poderão ser eliminados por mecanismos regulatórios do sistema imune (Carvalho e cols, 2011). A procura por possíveis alvos para diagnóstico deve levar em contar o quão imunogênico possa ser o antígeno afim de estimular o sistema imune que pode ter um efeito aumentado/dimunuido quando presente em sítios de glicosilações e fosforilações (Johnson L. N, 2009; Carvalho e cols, 2011; Chauhan e cols, 2013).

\subsection{Interação parasito-hospedeiro}

A coevolução dos hospedeiros e agentes patogênicos levou tanto ao desenvolvimento do sistema imune eucariótico para, entre outras funções, eliminar microrganismos invasores quanto à evolução de mecanismos específicos para os patógenos adentrarem as células eucarióticas contrariando as defesas do hospedeiro (Escoll e cols, 2015). Todos os hospedeiros mamíferos são alvos de infecção por vírus, bactérias, fungos e outras formas de patógenos. A relação parasito-hospedeiro é o fator mais importante para determinar se a infecção será bem-sucedida ou se será resolvida pelo hospedeiro. Vários mecanismos estão envolvidos nesta interação complexa e aspectos tanto do hospedeiro quanto do parasito são essenciais. Alguns parasitos desenvolveram mecanismos de evasão, tais como infecção e replicação intracelular, como no caso do gênero Leishmania e do parasito Trypanosoma cruzi (Morais e cols, 2015).

O primeiro passo para a interação entre o hospedeiro e estes parasitos protozoários intracelulares é a ligação do parasito à célula hospedeira. Estes protozoários têm uma variedade de moléculas secretadas ou de superfície que são usadas para modular a resposta da célula e, desta maneira, adentrar na célula 
hospedeira. Várias dessas moléculas estão envolvidas no desencadeamento de vias específicas de sinalização essenciais para a entrada do parasito e para sua sobrevivência intracelular (Morais e cols, 2015).

Os constituintes presentes na membrana de superfície de promastigotas são foco de interesse para entender a modulação da resposta da célula hospedeira (Vergnes e cols, 2002; Spath e cols, 2003), e muitos destes - incluindo glicoproteínas, proteoglicanos e glicolípidios - foram caracterizados mostrando um papel de proteção para o parasito (Silverman, 2008). As principais moléculas de superfície/secretadas de Leishmania que podem participar nessa interação parasito-hospedeiro incluem: gp63, as proteases de superfície de promastigotas (PSP), proteofosfoglicanos (PPG) e proteínas ancoradas por glicofosfatidilinositol (GIPL). Estas moléculas estão presentes em grandes quantidades nas formas promastigotas e amastigotas (VannierSantos e cols, 2002; Silverman e cols, 2008).

Apesar do importante potencial de proteínas superficiais/secretadas em Leishmania spp. durante a infecção e interação com seus hospedeiros, apenas um pequeno número destas proteínas de Leishmania $s p$. foram examinadas e tiveram suas funções desvendadas na interação parasito-hospedeiro (Bates e cols, 1978; Shakarian e cols, 1998; Sereno e cols, 2005; Silverman e cols 2008;). Com isso, um grande número de proteínas secretadas de Leishmania poderiam ser candidatas a novos alvos de diagnóstico sorológico devido ao fato de estarem sendo liberadas durante a infecção e, assim, esses antigenos poderiam ser reconhecidas e internalizadas por células $\mathrm{B}$. $\mathrm{O}$ antígeno se ligaria a $\operatorname{lgM}$ e $\lg \mathrm{D}$ de membrana em células $B$ naives, possibilitando que sejam ativadas e, logo, tornariam-se específicas para dado antígeno que, por consequinte, apresentariam o antígeno internalizado aos linfócitos T CD4 auxíliares que, por sua vez, estimulariam ou auxíliariam as células B a produzem anticorpos específicos contra este antígeno (Silverman e cols, 2008; Abbas e cols, 2011). Dentre as proteínas secretadas de Leishmania, foram identificadas peptidases que estariam sendo secretadas por vias não clássicas, em forma de microvesículas exossomais, estas proteínas poderiam ser usadas para desenvolver novos marcadores de diagnóstico para leishmaniose (Peacock e cols, 2007; Silverman e cols, 2008). 


\subsection{Proteases secretadas de Leishmania}

As enzimas degradativas que catalisam a clivagem de ligações peptídicas em proteínas ou em oligopeptídeos são conhecidas como proteases. Essas proteínas proteolíticas desempenham funções fisiológicas, sendo assim, essenciais para o controle homeostático de procariotos e eucariotos. Essas enzimas são referidas por alguns termos pela comunidade cientifica como protease, peptídase e peptídeo hidrolítico (Santos e cols, 2006; Rani e cols, 2012; Jisha e cols 2013). As proteases produzidas por tripanosomatideos desempenham funções importantes durante a infecção no hospedeiro (especialmente os parasitos T. cruzi e Leishmania spp.) que incluem a modulação do sistema imune do hospedeiro, invasão, destruição de tecidos do hospedeiro, a migração do parasito, o crescimento e o desenvolvimento e / ou a aquisição de nutrientes essenciais para a sobrevivência e proliferação necessários para continuar a infecção. Alem disso, as proteases de tripanosomatideos possuem características estruturais incomuns, concedendo-as uma característica de imunodominância que as faz se tornar alvos para desenvolvimento de vacinas e marcadores de diagnóstico (Santos e cols, 2006; Vermelho e cols, 2010).

Dentre as proteínas secretadas encontram-se algumas incluídas no Clã das metalo-peptídases (ME) que não tiveram seu papel específico elucidado após serem secretadas do parasito e que não foram testadas como marcadores de diagnóstico (Peacock e cols, 2007; Silverman e cols, 2008; Silverman e cols, 2010).

\subsubsection{Metalo-peptidases}

O termo metalo-peptidase engloba exopeptidases (peptidases que atuam clivando ligações pépticas próximo a região amino terminal $-\mathrm{NH}_{2}$ ) e endopeptidases (peptidases que atuam clivando ligações peptídas próximas a região carboxi terminal - $\mathrm{COOH}$ ) envolvidas na maioria dos processos biológicos, tais como a morfogênese, a atividade dos peptídeos de metabolismo biológico, os hormônios, desenvolvimento e regulação do ciclo celular e, também, do metabolismo de antibióticos (Santos e cols, 2006; Rani e cols, 2012) . As metalo-peptidases necessitam de cofatores, geralmente íns metálicos, como $\mathrm{Zn}^{2+}$, para calizar a hidrolise de uma ligação peptídica. Essas proteínas foram classificadas usando os recursos do banco de dados MEROPS (Rawlings e cols, 2015), que as agrupou em 14 clãs diferentes, ou seja, as separou de acordo com as características das enzimas que incluem origem, nomenclarura, 
classificação, substratos, sequencias aminoacídicas, estruturas e, também, com a quantidade de íons catalíticos necessários para sua função. Os clãs das metalopeptídases formados foram: MA, MC, MD, ME, MJ, MK, MM, MO, MP (peptidases que necessitam de apenas de um íon metálico) e MF, MG, MH, MQ (peptidases que necessitam de dois íons metálico) e subdivididos em famílias (Vermelho e cols, 2010; Sbardella e cols, 2012).

Estudos entre comparações genômicas e análises de secretomas relataram metal-peptidases zinco dependentes, como a leishmanolisina ou GP63, presente na superfície dos parasitos Leishmania sp. e Trypanosoma sp. Nos parasitos do gênero Leishmania, essa metalo-peptidase estaria envolvida em mecanismos da interação parasito-hospedeiro, a qual incluem: função protetora contra ação do sistema complemento, interação com células do hospedeiro, entrada e sobrevivência intramacrófagos (Ivens e cols, 2005; Motta e cols, 2013). Em organismos multicelulares, como o parasito Schistosoma mansoni, foram encontradas proteínas que dividem homologia com a GP63 de Leishmania sp., essas proteínas estariam presentes na superfície do parasito em estágio larval e contribuiriam na proteção do parasito contra o sistema complemento do hospedeiro (Devorák e cols, 2008).

\subsubsection{Clã Metalo-peptídase (ME), Família M16}

O Clã ME e formado por duas famílias, M16 e M44, na qual os ligantes de zinco foram previstos para ocorrer no motif His-Xaa-XaaGlu-His $(\mathrm{HXXEH})$, sendo o motif inverso encontrado praticamente no Clã MA (Rawlings e Barrett, 2012). A família M16 compreende peptidases zinco-dependentes distribuídas em subfamílias M16A, M16B e M16C que incluem: Insulinase, enzima de degradação da insulina; metalo-peptidase de processamento mitocondrial de subunidade alfa e beta (MPP); Pitrisina, precursor da protease III; Nardilisina; Ubiquinol-citocromo C redutase; e Coenzima PQQ da síntese de proteínas F (Mitchell e cols, 2015). Das três subfamílias, a M16B é estruturalmente conhecida e contém a MPP. Assim como outras metalo-peptídases, as metalo-peptidases da família M16 são inibidas por agentes quelantes (Rawlings e cols, 2015). 


\subsubsection{Metalo-peptidase de processamento mitocondrial}

A maioria das proteínas mitocondriais tem seus respectivos genes localizados no núcleo e são sintetizadas no citosol como precursores de proteínas. A exportação dessas proteínas ocorre por meio de peptídeos-sinal localizados na região N-terminal, que serão removidos posteriormente na mitocôndria. Essa remoção se dá por ação de clivagem proteolítica dirigida por metalo-peptidases de processamento mitocondrial (do inglês metallopeptidase, mitochondrial processing - MPP) (Shimokata e cols, 1998; Desy e cols, 2012). Dados da estrutura tridimensional de MPP do Clã ME, família M16, subfamília M16B (Figura 7), podem ser usadas como base para estudar outras MPPs da respectiva família por apresentarem grandese semelhanças estruturais (Rawlings e cols, 2015). Essa MPP é traduzida por dois genes formando um heterodímero constituído por uma subunidade alfa e uma subunidade beta. A subunidade alfa está envolvida no reconhecimento do substrato enquanto a subunidade beta é responsável pela atividade catalítica (Geiger e cols, 2010; Rawlings e cols, 2015).
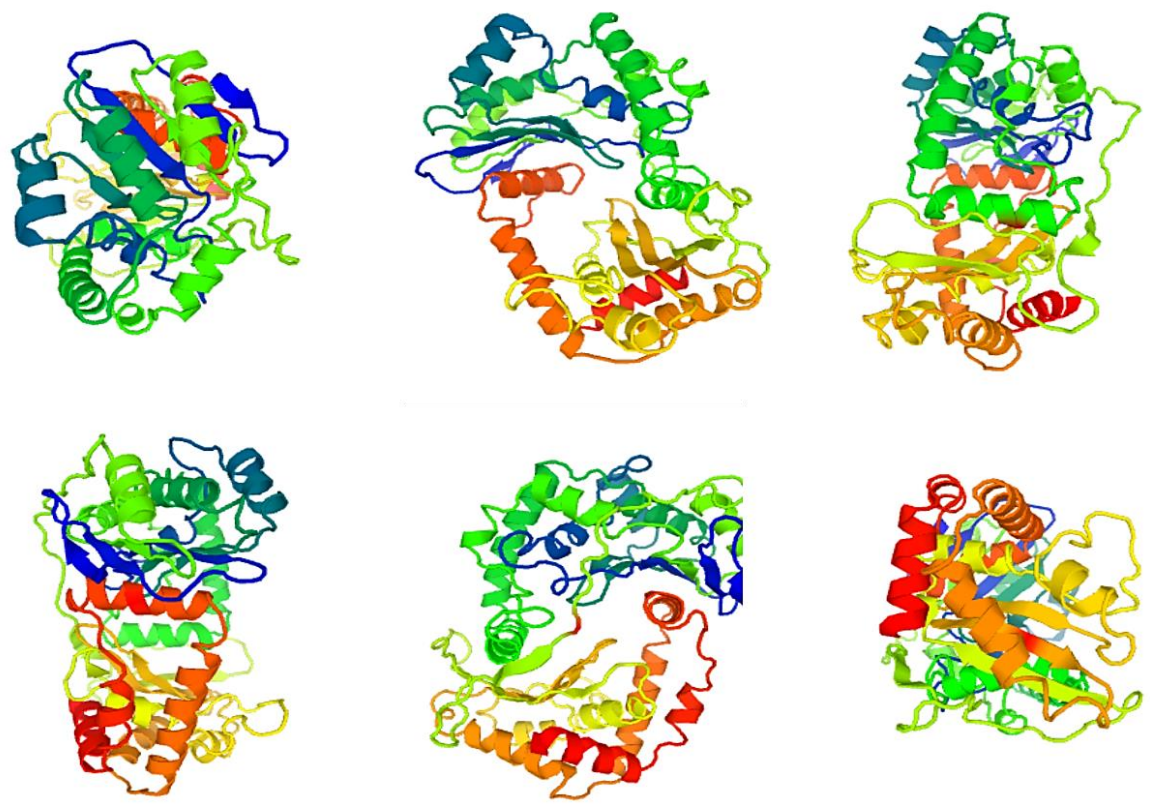

Figura 7: Estrutura da MPP da subunidade alfa do Clã ME, família M16, subfamília M16B de Homo sapiens. Fonte: Imagem retirada do servidor UniProt, código de acesso Q10713.

Em análise de secretoma de $L$. donovani foram encontrados MPPs secretadas e, entre elas, algumas pertencentes ao Clã ME, família M16 que estariam sendo secretadas por vias não-clássicas, sugerindo que a Leishmania use mecanismos de 
secreção baseada em exossomos para exportar e liberar moléculas que poderiam estar atuando na interação parasito-hospedeiro, podendo desempenhar funções imuno-moduladoras (Silverman e cols, 2008; Silverman e cols, 2010; Lambertz e cols, 2012; Silverman e Reiner, 2012). 


\section{JUSTIFICATIVA}

A leishmaniose visceral é uma patologia antropozoonótica que afeta milhões de indivíduos pelo mundo e que possui tratamento efetivo quando diagnóticada no inicio da doença. Os testes para diagnóstico mais sensíveis e específicos, como exames histopatológicos e diagnóstico molecular por PCR, são realizados em laboratórios especializados que possuem equipamentos de alto custo para aplicar tais técnicas que, consequinte, elevam o valor do exame. Dado a esses fatos, laboratórios de rotina, geralmente, não possuem os materiais e equipamentos para aplicar essas técnicas e, então, optam pelo uso de testes sorológicos para diagnóstico da leishmaniose visceral. Entretanto, a específicidade e sensíbilidade do teste sorológico depende do quão exclusivo possa ser o antígeno usado como marcador de diagnóstico, afim de não ocorrer reações cruzadas com antigenos pertencentes a diferentes parasitos e, ainda, poderiam ser utilizados para diferenciar animais vacinados de animais infectados.

Com isso, o presente trabalho tem como justificativa a avaliação da proteína metalo-peptídase de processamento mitocondrial do Clã ME, família M16, subfamília M16B de Leishmania infantum, como possível marcador para disgnótico sorológico de leishmaniose visceral canina e humana, sendo esta uma proteína secretada que poderia estar sendo reconhecida por células $\mathrm{B}$, que gerariam anticorpos específicos para este antígeno. 


\section{OBJETIVOS}

Objetivo Geral

O presente trabalho tem como objetivo avaliar a metalo-peptídase da subunidade alfa de processamento mitocondrial do Clã ME, família M16, subfamília M16B, do gene LDBPK_130760.1 de Leishmania donovani, presente em L. infantum, encontrada no banco de dados UniProt e de identificação XM_001464069.1 no banco de dados NCBI, como marcador para diagnóstico sorológico de leishmaniose visceral canina e humana.

\section{Etapas}

Analisar in silico o gene LdBPK_130760.1 de Leishmania donovani;

Clonar e expressar a proteína heteróloga em sistema procarioto e eucarioto;

Análisar comparativamente a reatividade de proteínas recombimantes produzidas pelos sistemas de expressão procarioto e eucarioto, em termos de reconhecimento antígeno-anticorpo. 


\section{MATERIAL E MÉTODOS}

\subsection{Desenvolvimento}

O estudo utilizou a sequência correspondente à proteína metalopeptidase, clã ME, família M16 - 1587 pb - 528 aminoácidos, de 57.656 kDa, código de acesso XP_001464106.1 do gene LDBPK_130760 no banco Protein do National Center for Biotechnological Information (NCBI) encontrada na cepa JPCM5 de Leishmania infantum, citada nos estudos de Peacock e cols (2007). Esta proteína foi relatada no trabalho de Peacock e cols (2007) e Silverman e cols (2008) como uma proteína secretada de Leishmania do complexo donovani, a qual poderia ser alvo para diagnóstico de leishmaniose visceral.

\subsubsection{Amostra biológica (soro)}

O trabalho foi aprovado pelo Comitê de Ética no Uso Animal - CEUA de número 106668/2014, disponível em Anexo A. Os soros usados no presente trabalho foram de cães infectados e não infectados, obtidos da Universidade Federal de Minas Gerais - UFMG. As amostras foram armazenadas em $-20^{\circ} \mathrm{C}$. Posteriormente, estas foram analisadas quanto a reatividade de anticorpos específicos contra a proteína heteróloga em estudo.

4.2. Predição da estrutura primária, sítios de fosforilação, glicosilação e de epitopos lineares de células $B$

As análises iniciais da proteína foram realizadas por meio das ferramentas online PredictionProtein para análise de estruturas físico-químicas (https://www.predictprotein.org/), preditor NetPhos v2.0 Server para análise de sítios de fosforilação (http://www.cbs.dtu.dk/services/NetPhos/ ), YinoYang $v 1.21 \mathrm{e}$ GlycoEP para análises de modificações pós-traducionais pela inserção de glicosídeos (http://www.imtech.res.in/raghava/glycoep/submit.html ) e pelo preditor BepiPred v1.0 Server para análise de possíveis epitopos lineares para células B (http://www.cbs.dtu.dk/services/BepiPred/ ). Os programas citados acima usaram parâmetros e pontos de corte padrões, exceto o programa BepiPred, este teve seu cutoff ajustado de 0.35 para 1.3 a fim de se aumentar os critérios de seleção de epitopos. 


\subsection{Desenho dos Primers}

Usando as ferramentas PrimerBlast e NebCutter (Vincze e cols, 2003), os iniciadores foram desenhados de acordo com a sequência de DNA em estudo (Figura 8B) e foram levados em conta os sítios de restrição dos vetores pGEM (promega) pLEXSY (Jena Bioscience) e pET-28a (Novagen), que seriam utilizados nos experimentos futuros, respectivamente. Foram adicionados uma trinca de timinas antecedendo as áreas de corte enzimático em cada primer, com a finalidade de facilitar a ação da respectiva enzima em seu sitio. Analisando os mapas dos vetores dos Anexos A B e C e comparando com os dados do NebCutter (Apêndice C), verificamos que seria necessário desenhar 2 pares de primers (Tabela 1) para que 0 gene pudesse ser inserido em cada plasmídeo posterior ao pGEM-T easy.

\subsection{Reação de polimerização em cadeia (PCR)}

A técnica de reação de polimerização em cadeia (do inglês Polymerase Chain Reaction) foi empregada utilizando primers específicos para o gene XM_001464069.1 que codifica a proteína XP_001464106.1 de Leishmania infantum. As sequências dos primers utilizados nas amplificações estão descritos na Tabela 1. Os primers LC 01/LC02 e LC 10/LC 11 geram bandas aproximadas de 1500 pb. Todos primers foram encomendados da IDT® (Integrated DNA Technologies).

Tabela 1: Primers utilizados nos ensaios moleculares por PCR.

\begin{tabular}{|c|c|c|}
\hline PRIMERS & SEQUÊNCIA & $\begin{array}{l}\text { ENZIMA DE } \\
\text { RESTRIÇÃO }\end{array}$ \\
\hline $\begin{array}{l}\text { LC } 01 \\
\text { e } \\
\text { LC } 02\end{array}$ & $\begin{array}{l}\text { 5`TTT CCA TGG GAT TCC GCC GTG TAG TCG CTC C 3` } \\
\text { 5`TTT GGT ACC CAG ACC CAT CTG GCG CAT GG 3`}\end{array}$ & Kpn I e Nco I \\
\hline $\begin{array}{l}\text { LC } 10 \\
\text { e } \\
\text { LC } 11\end{array}$ & $\begin{array}{l}\text { 5`TTT AAG CTT ATG TTC CGC CGT GTA GTC GCT 3` } \\
\text { 5'TTT CTC GAG TAA CTA CAG ACC CAT CTG GCG CAT 3` }\end{array}$ & Hind III e Xho I \\
\hline
\end{tabular}

Os pares de primer foram desenhados inserindo os pontos de clivagem das enzimas acima para cortar o plasmídeo e linearizar sua inserção no vetor. 
As amplificações do gene XM_001464069.1 de L. infantum com os primers LC 01/02, LC 10/11 foram feitas nas seguintes concentrações: 20ng de DNA genômico de Leishmania infantum obtido da Universidade Federal de Minas Gerais, tampão 10x da Ludwig Biotec (100 mM Tris- $\mathrm{HCl}$ pH 8.5, $500 \mathrm{mM} \mathrm{KCl);} 2$ mM MgCl$; 0,2 \mu \mathrm{M}$ de cada primer; 0,2 mM dNTPs (LGC Biotecnologia) e $2 \cup$ Taq DNA polimerase (Ludwig Biotec) incluídos no volume final de $25 \mu \mathrm{L}$. As reações foram realizadas no termociclador LifeTouch Bioer, como segue os programas abaixo:

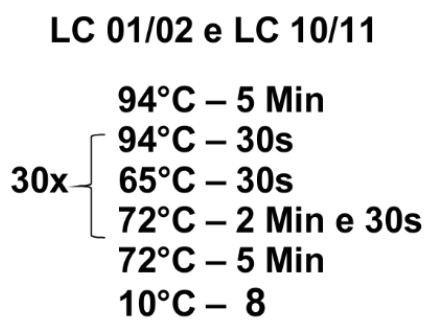

\subsection{Análise Eletroforética}

Os produtos de PCR, de extração de DNA plasmidial e de purificação após digestão enzimática foram visualizados em fotodocumentador após eletrofore em gel de agarose a $0,8 \%$ com Brometo de Etídeo $(\mathrm{EtBr})$ a $0,3 \mathrm{mg} / \mathrm{mL}$, utilizando tampão TrisAcetato-EDTA (TAE) 1X (Tris acetato $90 \mathrm{mM} \mathrm{pH} \mathrm{8,0} \mathrm{e} \mathrm{EDTA} 25 \mathrm{mM}$ ).

\subsection{Clonagem dos Produtos de PCR e dos Produtos de Digestão Plasmidial}

Após análise eletroforética, os amplicons da reação de PCR com sinais de banda mais intensos foram selecionados para clonagem, esses foram ligados pela ação da enzima T4 ligase à $10^{\circ} \mathrm{C}$ por 12 horas em aparelho termociclador (LifeTouch Bioer) a um plasmídeo, inicialmente em pGEM T-Easy (Promega) e após análise do sequenciamento foi feita digestão do DNA plasmidial anterior e realizada purificação e novas ligações aos plasmídeos pLEXSY-2 (Jena Bioscience) e pET-28a (NovaGen). As ligações seguiram o protocolo do fabricante, e em seguida, transformadas por choque térmico em bactéria Escherichia coli competente.

\subsubsection{Preparo de Células Competentes}

As células utilizadas para a transformação, Escherichia coli das linhagens $\mathrm{DH}$ $5 \alpha$ (Thermo Fisher Scientific) e Rosetta 2 (DE3) pLysS ${ }^{\top M}$, foram submetidas de acordo 
com o método de Inoue (Sambrook e Russel, 2006) para adquirirem competência. Um pré-inóculo de $25 \mathrm{~mL}$ de meio Luria Bertani (LB) (Invitrogem) contendo as bactérias foi deixado por um período de 12 horas a $37^{\circ} \mathrm{C}$, sob agitação de $200 \mathrm{rpm}$. Em seguida, volumes de $10 \mathrm{~mL}, 4 \mathrm{~mL}$ e $1 \mathrm{~mL}$ do pré-inóculo foram adicionados a três frascos erlenmeyer com capacidade para um litro, contendo $150 \mathrm{~mL}$ de meio LB. Os frascos erlenmeyer com $150 \mathrm{~mL}$ de LB acrescidos do pre-inóculo foram colocados sob agitação a $200 \mathrm{rpm}$ a temperatura de $18^{\circ} \mathrm{C}$ ao final da tarde. No dia seguinte, pela manhã, de cada frasco erlenmeyer foi retirado uma alíquota para realizar medição de densidade ótica (DO), repetindo a medição de DO a cada 40 minutos até atingir o valor 0.6 em comprimento de onda de 550nm. O erlenmeyer foi levado ao gelo por 10 minutos, após a incubação no gelo o meio líquido contendo as bactérias foi centrifugado a $2.500 \times$ g por 10 minutos, a $4{ }^{\circ} \mathrm{C}$. Em seguida, o pellet obtido foi ressuspenso em $48 \mathrm{~mL}$ de tampão TB (10 mM de HEPES, $15 \mathrm{mM}$ de $\mathrm{CaCl}_{2}, 250 \mathrm{mM}$ de $\mathrm{KCl}$, corrigindo o $\mathrm{pH}$ para 6,7 adiciona-se $55 \mathrm{mM}$ de $\mathrm{MnCl}_{2}$ ). Realizada nova centrifugação de acordo com os parâmetros acima, o pellet foi ressuspenso com 12 $\mathrm{mL}$ de tampão TB com DMSO na concentração de $7 \%$ do volume final. A solução foi incubada no gelo por 10 minutos e distribuídas em alíquotas para congelamento em $80^{\circ} \mathrm{C}$.

\subsubsection{Transformação bacteriana}

A transformação bacteriana seguiu o método de choque térmico (Protocols and Applications Guide, Third Edition, 1996), seguindo o protocolo: Para $50 \mu \mathrm{L}$ de Escherichia coli DH - 5a, acrescentou-se $3 \mathrm{uL}$ do produto da ligação no vetor (pGEM T-Easy, pLEXSY ou pET-28a), e incubou-se a mistura 30 min no gelo. Em seguida, os transformantes foram levados a banho maria a $42^{\circ} \mathrm{C}$ por 90 segundos e incubados imediatamente em gelo por 5 minutos. Adicionou-se $950 \mathrm{uL}$ de meio SOC $(0,5 \%$ de extrato de levedura, $2 \%$ de triptona, $10 \mathrm{mM}$ de $\mathrm{NaCl}, 2,5 \mathrm{mM}$ de $\mathrm{KCl}, 10 \mathrm{mM}$ de $\mathrm{MgCl}_{2}$, $10 \mathrm{mM}$ de $\mathrm{MgSO}_{4}$ e $20 \mathrm{mM}$ de glicose), e as células transformadas foram incubadas a $37^{\circ} \mathrm{C}$ por $1 \mathrm{~h}$ e $30 \mathrm{~min}$ sob agitação de $180 \mathrm{rpm}$. Após este período, as células foram centrifugadas a 2500 x g por 1 minuto a temperatura ambiente. $O$ pellet foi ressupenso em 100ul do sobrenadante e plaqueadas em meio LB sólido contendo ampicilina em $50 \mu \mathrm{g} / \mathrm{mL}$, X-gal e IPTG (pGEM), ampicilina em $50 \mu \mathrm{g} / \mathrm{mL}$ (pLEXSY-2), canamicina e 
cloranfenicol em $35 \mu \mathrm{g} / \mathrm{mL}$ (pET28 $\alpha$ ), a fim de selecionar as células resistentes ao antibiótico.

\subsubsection{Seleção dos recombinantes}

A seleção dos recombinantes ocorreu pela observação de colônias azuis e brancas resistentes a ampicilina, para colônias transformantes com o plasmídeo pGEM. Somente as colônias brancas foram escolhidas para serem semeadas em $5 \mathrm{~mL}$ de meio LB liquido contendo $50 \mu \mathrm{g} / \mathrm{mL}$ de ampicilina a $37^{\circ} \mathrm{C}$ por 12 horas sob agitação de 200 rpm. A seleção de colônias por diferenciação de colônias azuis e brancas é apenas para o vetor pGEM, para pLEXSY e pET a seleção é por PCR de colônias.

\subsubsection{Extração de DNA plasmidial}

Após o período de cultivo de 12 horas, as bactérias foram submetidas à extração de DNA plasmidial através do kit NucleoSpin® Plasmid (Macherey-Nagel) para extrações em pequenas escalas e NucleoBond® Xtra Midi (Macherey-Nagel) para extrações em medias e grandes escalas, todas extrações foram feitas conforme as instruções do fabricante. A análise dos insertos foi feita após eluição do DNA por meio de PCR com os primers respectivos usados anteriormente em cada reação e visualizados em gel de agarose a $0,8 \%$.

\subsection{Quantificação}

Os produtos de extração de DNA plasmidial, os produtos purificados após digestão enzimática e os produtos de purificação de proteína foram submetidas a quantificação em aparelho Espectrofotômetro NanoVue (GE Healthcare), usando $2 \mu \mathrm{L}$ de amostra.

\subsection{Sequenciamento}

Os produtos de extração plasmidial de cada clone que apresentaram bandeamento próximo de 1587 pares de bases em gel de agarose a 0,8\% foram submetidos à quantificação de DNA e, em seguida, foram alíquotados em 250ng/uL com volume final de $5 \mathrm{uL}$ e enviados para sequenciamento em aparelho Sequence Scanner da Applied Biosystems (Laboratorio de Biotecnologia - Universidade Católica de Brasilia), utilizando os primers Sp6 (reverse) e T7 (forward). 


\subsection{Análise das sequências}

As análises dos dados do sequenciamento foram realizadas pelo programa Chromas v2.6 (Technelysium) e pelo programa SnapGene (GSL Biotech LLC). Após visualização do cromatograma e correção das leituras que continham sobreposição de picos, leituras repetidas de uma mesma base e trocas de bases, as sequências foram alinhadas com os dados do servidor National Center for Biotechnology Information (NCBI - http://www.ncbi.nlm.nih.gov) através do algoritmo BLASTn usando os parâmetros: em Database colocada opção Others (nr etc.) - nucleotide collection (nr/nt), Organism colocado para Leishmania donovani species complex (taxid:38574), Program Selection colocado otimização para Somewhat similar sequences (blastn).

Os alinhamentos múltiplos foram realizados usando a ferramenta online Clustal Omega v1.21 (http://www.ebi.ac.uk/Tools/msa/clustalo/) e SnapGene (GSL Biotech LLC).

\subsection{Expressão das proteínas em modelo procariótico}

Os clones ligados ao vetor pGEM T-easy (Promega) que não sofreram deleções ou mutações de nucleotídeos foram selecionados para digestão enzimática com as enzimas descritas na Tabela 1. Uma pequena quantidade de produto da digestão $(5 \mu \mathrm{L})$ foi submetida a análise eletroforética conforme o item 4 para confirmar a liberação dos fragmentos do inserto. $O$ produto da digestão foi purificado em gel de agarose a $0.8 \%$ corado a $0.3 \mathrm{ng} / \mathrm{mL}$ de Brometo de Etídio e extraído usando o kit NucleoSpin ${ }^{\circledR}$ Gel and PCR Clean-up (Macherey-Nagel) nas condições descritas pelo fabricante. O purificado foi quantificado conforme $o$ item 4.6 e ligado ao vetor pET28a (NovaGen) conforme o item 4.5. O preparo das células competentes de bactéria E.coli da cepa Rosetta usadas para transformação foi realizado conforme o item 4.5.1 e a transformação como descrito no item 4.5.2, com a remoção do antibiótico ampicilina e adição de $35 \mathrm{ug} / \mathrm{mL}$ de cloranfenicol e $35 \mathrm{ug} / \mathrm{mL}$ de canamicina para o plaqueamento em meio LB solido.

\subsubsection{Expressão da proteína XP_001464106.1 em Escherichia coli cepa Rosetta}

As colônias crescidas em LB solido foram selecionadas e semeadas em $10 \mathrm{~mL}$ de meio LB liquido contendo $35 \mathrm{ug} / \mathrm{mL}$ de canamicina e $35 \mathrm{ug} / \mathrm{mL}$ de cloranfenicol. As 
bactérias foram divididas em grupos: Grupo A (Grupo controle), bactérias transformadas com vetor vazio induzidas com 0.5mM de IPTG e; Grupo B (Grupo teste), bactérias transformadas e induzidas com $0.5 \mathrm{mM}$ de IPTG. Todos os grupos foram colocados em agitador automático por um período de 12 horas a $37^{\circ} \mathrm{C}$ a 200rpm. Foram coletadas alíquotas de todos os grupos no volume de $1 \mathrm{~mL}$ em microtubos de $1.5 \mathrm{~mL}$ nos tempos de zero horas, 1 hora, 2 horas, 4 horas e 6 horas após indução. Todas as alíquotas foram centrifugadas a $2500 \times g$ por 15 minutos a temperatura ambiente. O meio de cultura foi separado do pellet e ambos foram armazenados $\mathrm{a}-20^{\circ} \mathrm{C}$.

4.9.2. Análise eletroforética em gel de policrilamida da expressão da proteína XM_001464069.1 em sistema procarioto.

A expressão da proteína foi avaliada por SDS-eletroforese em gel de policrilamida unidimensional (SDS-PAGE). Para este teste, utilizamos um volume de $250 \mathrm{~mL}$ de cultura e, também, usamos as amostras alíquotadas mencionadas no item 4.9.1. O pellet de cada uma das alíquotas foi ressuspendido em $10 \mathrm{~mL}$ de tampão de lise I (12,5 mM Na $2 \mathrm{mPO}_{4} ; 12,5 \mathrm{mM} \mathrm{NaH}_{2} \mathrm{PO}_{4} ; 0,5 \mathrm{M} \mathrm{NaCl}$ e $40 \mathrm{mM}$ de Imadazol) e homogeneizado por inversão e, após isso, cada tubo do homogeneizado foi levado a aparelho sonicador (BioLab) aplicando amplitude de 90 \% (com valor mínimo de 40\%) por 30 segundos e repetindo essa ação no total de três vezes, dando intervalos de 30 s entre cada repetição. Em seguida, todos os tubos foram centrifugados a $4000 \times g$ por 30 minutos a $4^{\circ} \mathrm{C}$ para separar os extratos solúveis de insolúveis. Os sobrenadantes foram transferidos para novos tubos de fundo cônico de $50 \mathrm{~mL}$ e ao pellet foram adicionados $10 \mathrm{~mL}$ de tampão de lise II (12,5 mM Na $2 \mathrm{HPO}_{4} ; 12,5 \mathrm{mM}$ $\mathrm{NaH}_{2} \mathrm{PO}_{4} ; 0,5 \mathrm{M} \mathrm{NaCl} ; 6 \mathrm{M}$ Uréia e10 mM de Imadazol) e realizado segundo tratamento afim de recuperar as proteínas insolúveis. Seguiu-se as mesmas condições aplicadas durante o primeiro tratamento. Ambas as amostras foram analisadas em gel de policrilamida a $10 \%$ com espessura de $1 \mathrm{~mm}$ corado com Coomassie Brilhant Blue $R$ (Sigma), aplicando 90V na fase concentradora e $180 \mathrm{~V}$ na fase separadora.

Foram alíquotados $1 \mathrm{~mL}$ de ambos os tratamentos $1 \mathrm{~mL}$ e mantidos em estoque a $-80^{\circ} \mathrm{C}$. Foram transferidos $25 \mu \mathrm{L}$ de amostra de cada tratamento para novos microtubos de $1,5 \mathrm{~mL}$ e adicionados $5 \mu \mathrm{L}$ de tampão de amostra $5 x$ concentrado, as amostras foram então fervidas por 5 minutos e, posteriormente, aplicadas em gel de 
policrilamida a $10 \%$ com espessura de $1 \mathrm{~mm}$, aplicando $90 \mathrm{~V}$ na fase concentradora e $180 \mathrm{~V}$ na fase separadora e corado com Coomassie Brilhant Blue (Sigma). O material restante foi designado para purificação de proteína.

\subsection{Expressão de proteínas em modelo eucariótico}

Leishmania tarentolae (L. tarentolae)

Formas promastigotas de $L$. tarentolae (Jenabioscience) foram cultivadas em meio $\mathrm{BHI}$ suplementado com $0.25 \%$ de Hemina e $1 / 1000$ de penicilina e estreptomicina (PenStrep). Geneticina (G-418) foi adicionada na concentração de 50 $\mathrm{ug} / \mathrm{mL}$ após eletroporação. $\mathrm{O}$ cultivo dos parasitos foi feito a temperatura de $26^{\circ} \mathrm{C}$ em ambiente protegido de iluminação.

\subsubsection{Eletroporação em L. tarentolae}

O protocolo seguido para a metodologia foi o recomendado pelo fabricante (Jenabioscience). Inicialmente, um pré-inóculo foi realizado em volume de $10 \mathrm{~mL}$ de meio $\mathrm{BHI}$ suplementado com soro fetal bovino, Hemina e PenStrep e incubado em frasco de cultura de células por $72 \mathrm{~h}$ à $26^{\circ} \mathrm{C}$. A cultura foi diluída em 1:10 em $10 \mathrm{~mL}$ do mesmo meio de cultura e foi mantida em $26^{\circ} \mathrm{C}$ por 24 - 48 horas. No dia seguinte, checou-se a densidade óptica (D.O.) e, quando atingida a D.O. de 1.4, em análise de comprimento de onda de 600nm no aparelho Ultrospec®) 1000 (Amersham pharmacia biotech), as células foram centrifugadas por 3 minutos em $2000 \times g$ a temperatura ambiente. Após centrifugação foi estimada uma concentração $6 \times 10^{8}$ células $/ \mathrm{mL}$, com base nas recomendações do fabricante. O pellet foi ressuspendido com 2,5 mL de meio de cultura remanescente e incubado em gelo por 10 minutos. Paralelamente, foram introduzidos $20 \mu \mathrm{g}$ de plasmídeo pLEXSY (Anexo C) com o inserto em $50 \mu \mathrm{L}$ de água destilada em cuveta de eletroporação, sendo incubada no gelo. Foram adicionados $350 \mathrm{uL}$ de células pré-refrigeradas nos tubos contendo DNA, esse foi levado ao gelo. As cubetas foram eletroporadas a $450 \mathrm{~V}, 450$. Após o pulso, as cubetas voltaram ao gelo por 10 minutos. As células eletroporadas foram transferidas para frasco de cultura de células arejado contendo $10 \mathrm{~mL}$ de meio $\mathrm{BHI}$ suplementado com hemina, penicilina e estrepitomicina e, após período de $24 \mathrm{~h}$, foi adicionado 
geneticina, após isso, os frascos foram colocados para incubar por 48 horas a $26^{\circ} \mathrm{C}$ em local protegido da luz.

4.10.2. Coleta de material para análise de expressão do gene LDBPK_130760 em L. tarentolae

Para verificar se as $L$. tarentolae estariam expressando a proteína codificada pelo gene em análise, dividimos as culturas destes parasitos em grupos diferentes: Grupo A (grupo controle), L. tarentolae selvagens; e Grupo B (grupo teste), transfectadas com vetor ligado ao inserto que codifica a proteína XP_001464106.1. Todos os grupos foram colocados em estufa por um período de 48 horas a $26^{\circ} \mathrm{C}$. Foram coletadas alíquotas de todos os grupos no volume de $10 \mathrm{~mL}$ em tubos falcon de $15 \mathrm{~mL}$ durante cada nova semeadura por um período total de 60 dias, duas semeaduras por semana. Todas as alíquotas foram centrifugadas a $2500 \times g$ por 15 minutos a temperatura $4^{\circ} \mathrm{C}$. O sobrenadante foi removido e o pellet de cada alíquota foi armazenado a $-20^{\circ} \mathrm{C}$.

\subsubsection{Extração de DNA de L. tarentolae}

A extração de DNA dos cinetoplastidas foram realizadas de acordo com o método de fervura modificado (Bashiruddin, 1988). As alíquotas contendo o pellet das culturas, item 3.9.2, foram ressuspensas em $1 \mathrm{~mL}$ de PBS ( $\mathrm{NaCl} 137 \mathrm{mM}, \mathrm{KCl}$ 2,7mM, $\mathrm{Na}_{2} \mathrm{HPO}_{4} 10 \mathrm{mM}, \mathrm{KH}_{2} \mathrm{PO}_{4} 2 \mathrm{mM0}$; pH 7.4) e centrifugadas a 1500 x g por 10 min à $4^{\circ} \mathrm{C}$. O pellet foi lavado por três vezes com PBS e centrifugado nas mesmas condições. A cada lavagem, os sobrenadantes eram descartados. Após a última lavagem, o pellet foi ressuspendido em $100 \mu \mathrm{L}$ de PBS $1 \mathrm{x}$ e levado ao banho maria para fervura. $\mathrm{O}$ material foi fervido a $100^{\circ} \mathrm{C}$ por $5 \mathrm{~min}$. Após fervura, os tubos foram centrifugados nas mesmas condições anteriores. O sobrenadante foi removido para novo microtubo de $1,5 \mathrm{~mL}$ e o pellet descartado. Foram usados $5 \mu \mathrm{L}$ do sobrenadante para reações de PCR.

4.10.4. Análise eletroforética em gel de policrilamida da expressão da proteína XP_001464106.1 em sistema eucarioto

A expressão da proteína foi avaliada por SDS-PAGE. Para este teste, aumentamos o volume da cultura para $250 \mathrm{~mL}$, mantidos a temperatura de $26^{\circ} \mathrm{C}$ 
durante o crescimento. Ao atingir DO de 1.4, conforme item 4.9.1, a densidade celular da cultura estaria aproximadamente em $6 \times 10^{7}$ células $/ \mathrm{mL}$. As culturas foram transferidas para tubos de fundo cônico de $50 \mathrm{~mL}$ e centrifugados a $2000 \times \mathrm{g}$ por 20 min a $4^{\circ} \mathrm{C}$. Após essa etapa, os procedimentos aplicados foram os mesmos do item 3.9.2.

4.11. Purificação da proteína recombinante dos sistemas eucarioto e procarioto por cromatografia de afinidade.

A purificação foi realizada segundo o protocolo do fabricante (Qiagen), com as seguintes alterações: Adicionamos $1 \mathrm{~mL}$ da matriz Ni-NTA (Qiagen) a uma minicoluna de $3 \mathrm{~mL}$, permitindo a passagem do sobrenadante por ação gravitacional e retendo as matrizes. Em seguida, em colunas diferentes, foram adicionados $2 \mathrm{~mL}$ de solução de lise I (12,5 mM Na2HPO ; 12,5 mM NaH $2 \mathrm{PO}_{4} ; 0,5 \mathrm{M} \mathrm{NaCl}$ e $10 \mathrm{mM}$ de Imadazol) e de lise II (12,5 mM Na $2 \mathrm{HPO}_{4} ; 12,5 \mathrm{mM} \mathrm{NaH}_{2} \mathrm{PO}_{4} ; 0,5 \mathrm{M} \mathrm{NaCl} ; 6 \mathrm{M}$ de Uréia e $10 \mathrm{mM}$ de Imadazol) de acordo com as amostras que receberam os tratamentos do item 3.9.1. Depois de equilibrar a matriz, adicionou-se as amostras sônicadas do sistema procarioto e do sistema eucarioto. Todo material que passou pela matriz foi coletado. Posteriormente, foram adicionados $4 \mathrm{~mL}$ de solução de lavagem I (12,5 mM $\mathrm{Na}_{2} \mathrm{HPO}_{4} ; 12,5 \mathrm{mM} \mathrm{NaH} 2 \mathrm{PO}_{4} ; 0,5 \mathrm{M} \mathrm{NaCl}$ e $40 \mathrm{mM}$ de Imadazol) e solução de lavagem II (12,5 mM Na $2 \mathrm{HPO}_{4} ; 12,5 \mathrm{mM} \mathrm{NaH}_{2} \mathrm{PO}_{4} ; 0,5 \mathrm{M} \mathrm{NaCl} ; 6 \mathrm{M}$ de Uréia e $40 \mathrm{mM}$ de Imadazol), coletando sempre o material de fluxo de passagem. Por fim, a proteína foi recuperada com $1 \mathrm{~mL}$ de solução de eluição I (12,5 mM Na $2 \mathrm{HPO}_{4} ; 12,5 \mathrm{mM}$ $\mathrm{NaH}_{2} \mathrm{PO}_{4} ; 0,5 \mathrm{M} \mathrm{NaCl}$ e $250 \mathrm{mM}$ de Imadazol) e solução de eluição II (12,5 mM $\mathrm{Na}_{2} \mathrm{HPO}_{4} ; 12,5 \mathrm{mM} \mathrm{NaH}_{2} \mathrm{PO}_{4} ; 0,5 \mathrm{M} \mathrm{NaCl} ; 6 \mathrm{M}$ uréia e $250 \mathrm{mM}$ de Imadazol) e coletouse o material em microtubos de $1,5 \mathrm{~mL}$, armazenando a $-20^{\circ} \mathrm{C}$.

\subsubsection{Redução da concentração de uréia por diálise}

As proteínas purificadas de bactéria que foram submetidas ao tratamento ॥ tiveram de passar por membrana de diálise afim de reduzir a concentração de uréia. A membrana de celulose tubular de dialise (Sigma), diâmetro de $16 \mathrm{~mm}$, comprimento de $12 \mathrm{~cm}$ e retenção de proteínas maiores que $12 \mathrm{kDa}$ foi usada para esse processo. A membrana foi preparada de acordo com as normas do fabricante, uma das 
extremidades foi vedada e a amostra foi adicionada dentro da membrana e, consecutivamente, a outra extremidade foi lacrada. A membrana com a amostra foi colocada em recipiente contendo $2000 \mathrm{~mL}$ de PBS e deixada sob agitação constante por $12 \mathrm{~h}$ a $4^{\circ} \mathrm{C}$. Posteriormente, o material dialisado foi recuperado e transferido para novo microtubo de $1,5 \mathrm{~mL}$ e armazenado a $-20^{\circ} \mathrm{C}$.

\subsection{Western Blotting}

As amostras obtidas do item 4.10 foram separadas eletroforeticamente e transferidas para membrana de nitrocelulose de $0.45 \mu \mathrm{m}$ (Bio-Rad), seguindo a metodologia de Towbin e cols (1979). A transferência foi realizada usando o sistema Miniprotean Cell $\circledast$ (Bio-Rad) e o marcador de peso molecular pré-marcado utilizado foi Novex®sharp Pre-Stained (invitrogen).

Após a transferência, a membrana foi bloqueada com PBS Tween $0.01 \%$, com $2.5 \%$ de leite desnatado (Molico - Nestle) e colocado para incubar por $12 \mathrm{~h}$ a $4 \stackrel{\circ}{\circ} \mathrm{C}$. Posteriormente, a membrana foi lavada três vezes com PBS Tween $0.01 \%$ por 5 minutos e colocada em agitação. Foram adicionados anticorpo primário anti-His Tag (LifeTechnologies) na proporção de 1:500 para os ensaios de detectação de calda de histidina e soro na proporção de 1:200 em PBS nos ensaios de teste da proteína heteróloga contra anticorpos do hospedeiro, ambas membranas foram colocadas para incubar a temperatura ambiente sob agitação constante. Após o tratamento com o anticorpo primário/soro do paciente, foram realizadas três lavagens em PBS Tween $0.01 \%$ por $5 \mathrm{~min}$. As membranas receberam tratamentos com anticorpo secundário anti IgG murino (Life Technologies) conjugado com fosfatase alcalina nos ensaios para detecção da proteína heteróloga e anticorpo secundário anti-lgG canino conjugado com HRP para ensaios de reatividade da proteína, ambos tratamentos com anticorpos secundários foram feitos nas diluições de 1:1000, seguida de incubação a temperatura ambiente por 1 hora sob agitação constante. Anticorpo anti -His Tag conjugado com fosfatase alcalina (Sigma) foi diluído em PBS leite 2\% (1:10.000). Depois, foram realizadas cinco lavagens com PBS Tween $0.01 \%$ e, por último, a membrana foi revelada em BCIP/NBT (Sigma), na concentração indicada pelo fabricante. A revelação foi interrompida com água destilada. 
4.13. Ensaio de Imunoabsorbância Enzimática (Enzyme Linked Immunosorbent Assay - ELISA)

Microplacas de alta afinidade de ligação com fundo plano de 96 cavidades (Greiner bioone) foram sensibilizadas separadamente com 100 $\mu \mathrm{L} /$ poço, contendo 5 $\mu \mathrm{g} / \mathrm{mL}$ das proteínas purificadas dos itens 4.9 .2 e 4.11, em tampão de revestimento (carbonato-bicarbonato) $\mathrm{pH}$ 9,6 (0.03 $\mathrm{M} \mathrm{NaHCO}_{3} 0 ; .015 \mathrm{M} \mathrm{Na}_{2} \mathrm{CO}_{3}$ ) e incubadas por $12 \mathrm{~h}$ a $4^{\circ} \mathrm{C}$. Em seguida, os excessos de antígenos foram removidos por meio de três lavagens com PBS pH 7,4 contendo 0,05\% de Tween-20 (PBS-T). Os sítios de adesão livres foram bloqueados com 100 $\mu \mathrm{L} /$ poço de PBS pH 7,4 acrescidos de $10 \%$ de SFB (soro fetal bovino) da Gibco, seguido por incubação de $1 \mathrm{~h}$ a temperatura ambiente. Ao final, repetiu-se o procedimento de lavagem. Os soros dos cães foram diluídos a 1:50, 1:100 e 1:1000 em PBS/SFB 10\% e adicionados $100 \mu \mathrm{L} /$ poço, em duplicata. Após incubação de $1 \mathrm{~h}$ a temperatura ambiente, as placas foram novamente lavadas com PBS-T. O conjugado, composto por anticorpos anti-lgG canino marcado com HRP (Novex - Life Technologies) foi diluído 1: 2000 em PBS/SFB 10\% e, em seguida, $100 \mu \mathrm{L} /$ poço foram adicionados às placas seguida por incubação de $1 \mathrm{~h}$ a temperatura ambiente, sendo envolvidas por papel alumínio durante essa etapa. Após incubação, o excesso do conjugado foi retirado através de cinco lavagens com PBS-T. A revelação da reação foi feita pela adição de $50 \mu \mathrm{L} /$ poço de $\mathrm{H}_{2} \mathrm{O}_{2}$ (Dinâmica) em tampão fosfato-citrato $\mathrm{pH}$ 5,0 adicionado de cromógeno OPD (o-Phenylenediamine dihydrochloride - Sigma). A reação foi feita em local sob proteção de luz, passados 10 minutos, essa foi interrompida pelo acréscimo de $50 \mu \mathrm{L} /$ poço de $\mathrm{H}_{2} \mathrm{SO}_{4}$ (ácido sulfúrico). A leitura foi feita em espectrofotômetro (BioTeK-Synergy HT) a $490 \mathrm{~nm}$.

Para estabelecer o ponto de corte da reação entre soro reagentes e não reagentes foram usados cinco animais controles negativos, cujos soros foram coletados na Universidade Federal de Minas Gerais - UFMG. Assim, o "cut-off' foi calculado utilizando-se a média aritmética dos valores de absorbância dos negativos, acrescentando-se ao valor, três desvios padrão da média.

\subsection{Análise estatística}

Os resultados obtidos pelo ELISA, item 4.13, foram analisados pelo programa Graphic Pad Prism 5 (GraphPad Software). O teste de análises de colunas - teste t foi 
aplicado. A aplicação do teste $\mathrm{t}$ foi realizada de forma pareada para verificar o valor de significância ( $p$ value) dos resultados. 


\section{RESULTADOS E DISCUSSÃO}

O diagnóstico laboratorial para leishmaniose visceral canina e humana pode ser realizado por diversas técnicas que variam da evidenciação direta do parasito em tecidos do hospedeiro, procura pelo DNA do parasito em amostras do hospedeiro e, mais comumente, testes que envolvem reações antígeno-anticorpo (Pereira, 2013; Sakkas e cols, 2016). Contudo, a busca por metodologias que possam ser aplicadas em laboratórios de rotina acusa a melhor alternativa sendo o diagnóstico sorológico (Pereira e cols, 2013). Em busca de aprimorar os ensaios sorológicos diversas pesquisas foram e continuam sendo realizadas com o intuito de encontrar um marcador para diagnóstico sorológico de LV que tenha uma alta sensibilidade, específidade, com uma fácil aplicação e baixos custos (Gao e cols; Menezes-Sousa e cols, 2015). Nesse contexto, muitos antigenos de superfície e secretados de Leishmania passaram a serem alvejados como possíveis marcadores de diagnóstico, uma vez que poderiam estar interagindo com células $B$ e, assim, produzindo anticorpos (Vergnes e cols, 2002; Peacock e cols, 2007; Silverman e cols, 2008).

Nos estudos realizados por Peacock e cols (2007) e por Silverman e cols (2007 e 2008) foram apontadas uma grande quantidade de proteínas que estariam sendo secretadas por Leishmania e que, ainda, não foram estudadas. Baseado nos trabalhos relatados, esse estudo teve como objetivo analisar a Metalo-peptídase da subunidade de processamento mitocondrial do Clã ME, família M16, subfamília M16B para diagnóstico sorológico de LV.

Contudo, previamente aos testes in vitro se faz necessário uma sondagem do possível candidato por meio de análises in silico que visaram analisar se a MPP possuía proteínas ortólogas nos organismos a serem diagnosticados e determinar se o antígeno candidato apresentava determinantes imunogênicos (Carvalho e cols, 2011; Wen e cols, 2016).

\subsection{Análise in silico}

A análise in silico teve como alvo a proteína XP_001464106.1 de L. infantum, uma proteína composta por 528 aminoácidos (Figura 8A) de 57.656 kDa, codificada pela sequência de DNA XM_001464069.1 do gene LDBPK_130760, depositada no banco de dados Nucleotide do NCBI, composta por 1587 nucleotídeos (Figura 8B). estudo inicialmente abordou sequências similares entre organismos eucariotos 
unicelulares da família Trypanosomatidae (Figura 9) e organismos eucariotos multicelulares afim de encontrar similaridades entre elas. As análises em busca de proteínas com identidades $>60 \%$ em organismos eucariotos multicelulares visam discartar proteínas que possuam ortólogas nesses organismos, esse fato interferiria em testes de imunogenicidade da proteína alvo.

\begin{abstract}
A
MFRRVVAPAPVAATAACAGQARSIYEYKFGQTPLTOPFGGTSRLPPGPSSKPAPVAAGKVEITKLHNG ARVITHNLGGPSVSVGAYILAGPAYDPPSAPGTGAMMHLALTTSNYNNSLFQLDRNIRSVGAAQSHF EKHKHYIGIRIDARADKWKSAAPTSSLSQRRQLQNQKQAEQQFSLNLVQDNIFTCIAAPRFHEPDVER FRDTIDNQVEELRWQCPAEYAKQMLETVAFYREPLGNPRFVPAMSNGIISSSVLLEQYSRYVVPSRVV VSGVNVDHAALIAEYENTPFPHSASAPHHARAQPCAVNWKDEAAQYTGGERHDHEDRPKVMGTKP DMDPESIIAVGWLAYGKDRKMTKDHAASMVVGALMDIGFSGRMRCGAPDEMHEHTGLRAFYSPY QTAGLIGFTAKAEPQAAVRMVTDAVRMVQANKASVADSMLSVAKKMARTQFMVQNVDTIRDYCD YLGTCLAVDSDSTLATSVEEVVDAINSVNAVDVKRVYETMFSNKTSLYGHGEMLGFPSMRQMGL
\end{abstract}

B

ATGTTCCGCCGTGTAGTCGCTCCGGCGCCGGTGGCGGCCACCGCAGCCTGCGCTGGGCAGGCTCGCAGCAT CTACGAGTACAAG TTCGGTCAGACCCCCCTCACCCAACCGTTTGGCGGAACCTCTCGCCTGCCGCCTGGCCC CTCGTCGAAGCCTGCCCCGGTTGCTGCCGGGAAGGTGGAGATCACGAAGCTGCACAACGGCGCGCGCGTCA TCACGCACAACCTCGGTGGACCGTCGGTGTCCGTTGGTGCCTACATACTCGCCGGCCCCGCCTACGACCCAC CGAGCGCGCCGGGCACGGGAGCCATGATGCACCTTGCCCTGACGACGAGCAACTACAATAATTCGCTGTTCC AGCTTGACCGCAACATTCGCAGTGTCGGCGCCGCCCAGTCGCACTTCGAGAAGCACAAGCACTACATCGGCA TTCGCATCGACGCCCGCGCCGACAAGTGGAAGAGCGCCGCGCCGACGTCATCGCTTTCACAGCGGCGGCAG CTGCAGAACCAGAAGCAAGCGGAGCAGCAGTTCTCGTTGAATCTGGTGCAGGACAACATCTTTACCTGCATC GCCGCGCCCCGCTTCCACGAGCCGGATGTGGAGCGCTTCCGTGACACCATTGACAACCAGGTCGAGGAGCT CCGCTGGCAATGCCCAGCCGAGTACGCGAAGCAGATGCTGGAGACGGTCGCCTTCTACCGTGAGCCGCTCG GCAACCCTCGCTTCGTGCCGGCGATGAGCAACGGCATCATTTCGAGCAGCGTACTGCTGGAGCAGTACAGCC GCTACGTCGTGCCGTCGCGCGTCGTCGTCTCCGGCGTCAACGTCGATCACGCCGCGCTGATTGCCGAGTACG AGAACACCCCGTTCCCACACTCCGCCTCGGCACCGCACCACGCCCGCGCGCAGCCGTGCGCGGTGAACTGG AAGGATGAGGCCGCTCAGTACACCGGGGGCGAGCGCCACGACCACGAGGACCGCCCCCAAGGTAATGGGAA CGAAGCCGGACATGGACCCGGAGTCCATCATCGCCGTCGGCTGGCTCGCGTACGGCAAAGACAGGAAGATG ACGAAGGACCACGCCGCCTCGATGGTCGTGGGGGCGCTGATGGACATCGGGTTCAGCGGCCGCATGCGCTG CGGCGCCCCGGATGAAATGCACGAGCACACGGGCCTGCGCGCCTTCTACAGCCCCTACCAAACGGCTGGCC TGATCGGCTTCACGGCGAAGGCAGAGCCGCAGGCAGCGGTGCGCATGGTGACGGACGCTGTGAGGATGGTG CAAGCAAACAAGGCCTCTGTCGCGGACTCGATGCTGTCCGTGGCGAAAAAAATGGCGAGAACGCAGTTCAT GGTGCAGAATGTCGACACCATTCGCGACTACTGCGACTACCTTGGCACCTGCCTCGCCGTGGATAGCGACTC GACCCTAGCCACATCGGTCGAAGAGGTTGTCGACGCCATCAACTCTGTCAACGCGGTGGATGTGAAGCGGGT GTACGAGACGATGTTCTCGAACAAGACCAGCCTGTACGGCCACGGCGAGATGCTCGGCTTCCCTTCCATGCG CCAGATGGGTCTGTAG

Figura 8: Sequências proteica e nucleotídica da MPP A Sequência da proteína XP_001464106.1. B Sequência de referência XM_001464069.1 do gene LDBPK_130760. Sequências disponíveis no NCBI, nos bancos "Protein" e "Nucleotide".

Posteriormente, foi verificado se a proteína teria qualidades como possível alvo para diagnóstico, então, foram analisadas suas propriedades físico-químicas, seus sítios de fosforilação, suas modificações pós-traducionais por adição de glicosídeos e, também, analisada a presença de possíveis epitopos lineares para células B. De acordo com Gupta (2007) e Wen e cols (2016), a verificação das qualidades citatas são importantes fatores que influênciam na imunogenicidade do antígeno como, por 
exemplo, o tamanho da molécula que deve estar acima de $14 \mathrm{kDa}$ pois, geralmente, moléculas de grande massa molecular (albumina do ovo e tireoglobulina) são melhores imunógenos por serem mais propensas a possuirem áreas imunogênicas formadas por um ou mais aminoácidos com ou sem modificações pós-tradudionais (fosforilação e glicosilação) que estimulem o sistema imune (Johnson, 2009; Chauhan e cols, 2013). Nos trabalhos de Wen e cols (2016) e de Carvalho e cols (2011), as proteínas selecionadas para cada estudo tiveram, em sua maioria, uma massa maior que $14 \mathrm{kDa}$, e suas análises in silico envolveram as qualidades citadas anteriormente.

As análises baseadas nas informações da ferramenta Blastn (Apêndice D) revelaram sequências com identidade $>85 \%$ entre alguns membros do gênero Leishmania (L. donovani, L. infantum, L. major, L. mexicana, $L$ paramensis e $L$. braziliensis). De acordo com Peacock e cols (2007), os genes expressos por espéciesespecíficas de parasitos mostraram níveis de expressão diferentes, os quais podem estar correlacionados à patogênese de sua respectiva doença. Ao verificar nos bancos de dados do NCBI, usando as ferramentas Blastp e Blastn, por proteínas ortólogas a proteína XP_001464106.1 em Canis familiaris, Homo sapiens e Mus musculus foram encontradas proteínas com identidade menor que $18 \%$, sugerindo que elas talvez não possuíssem a mesma função e que a MPP em estudo poderia ser usada nestes organismos (Duthie e cols, 2016).

Os resultados do alinhamento múltiplo com mais de $60 \%$ de identidade sugerem que a MPP esteja presente nas outras espécies de Leishmania e que em ensaios in vitro poderia ocorrer reatividade com esses organismos, porém, em Trypanosoma cruzi a proteína apresenta cerca de $50 \%$ de identidade a qual sugere que possa ser uma proteína diferente (Carvalho e cols, 2011). Contudo, trabalhos na literatura utilizaram proteínas que apresentaram altas identidades, porém, essas proteínas tiveram regiões que se diferenciavam uma das outras e estas foram usadas para formar uma sequência quimera usando resíduos de uma mesma proteína ou mesclando com resíduos de outras proteínas que pode ser usada para diagnóstico (Soto e cols; 1998; Rosati e cols, 2001; Bottino e cols, 2013; Duthie e cols, 2016). 


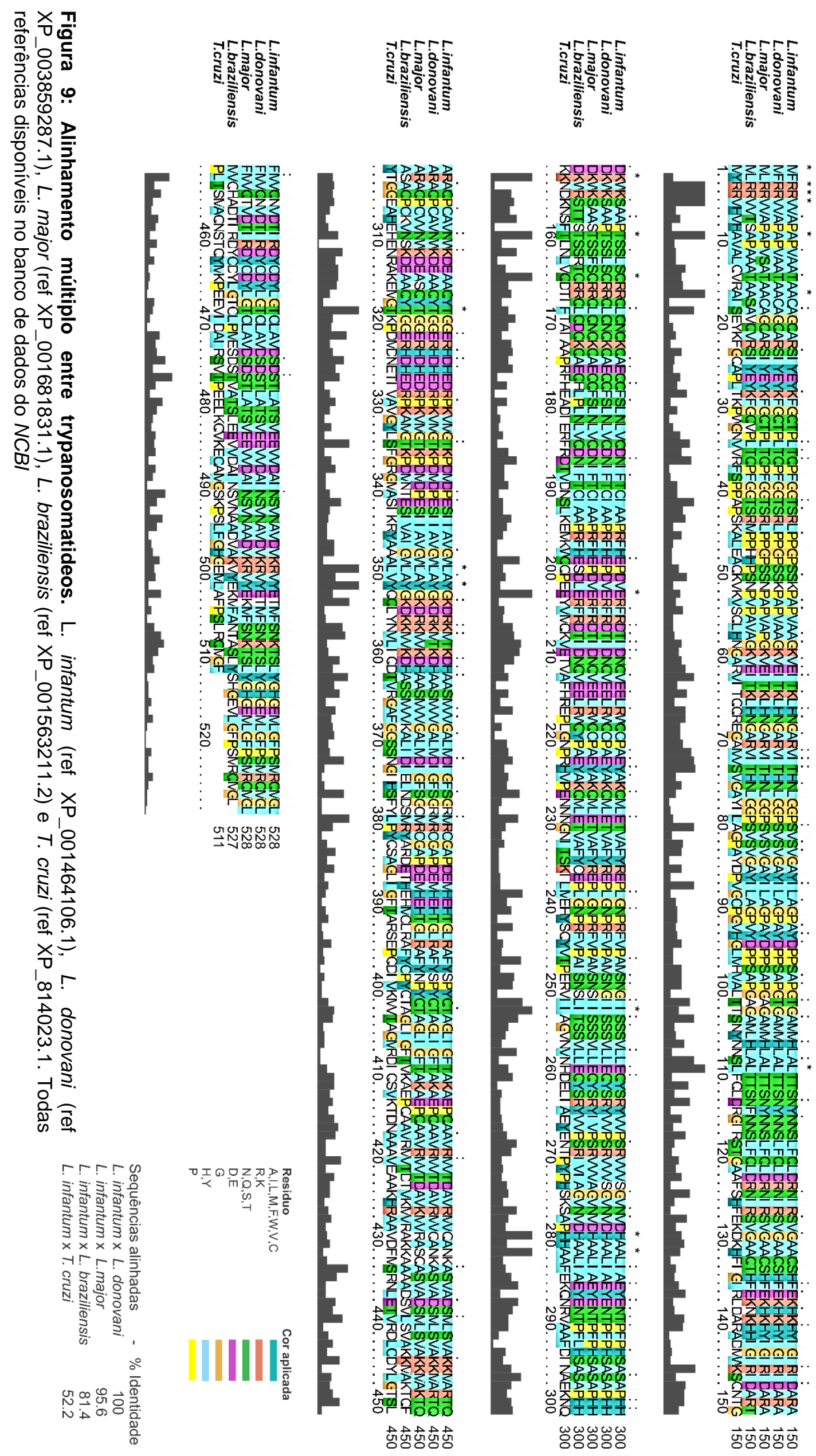




\subsubsection{Análise da estrutura físico-química da proteína}

Com auxílio da ferramenta PredictProtein (Rost e Sander, 1993a, 1993b; 1994a, 1994b; Rost e cols, 2004), foi feita uma caracterização preliminar de propriedades físico-químicas da proteína como: porcentagem relativa de estruturas secundárias, famílias de proteínas relacionadas, acessibilidade relativa ao solvente, composição de estrutura primária e secundária (Figura 10). De acordo com a Figura $10 \mathrm{~A}$, a proteína referida é majoritariamente composta por loops e hélices, com uma porcentagem menor de folhas beta. Ao conciliar esses dados com a literatura foi visto que a composição da estrutura secundária pode dotar a proteína com propriedades antigênicas, como visto em Wen e cols (2016). Alanina e valina, que são aminoácidos hidrofóbicos, aparecem em maior concentração (Figura 10B). Na Figura 10C há uma estimativa de $47,35 \%$ de resíduos de aminoácidos expondo mais de $16 \%$ de sua superfície, o servidor correlacionou às áreas em branco com o símbolo ${ }^{* * *}$ como áreas intermediarias entre a interface exposta e não exposta ao solvente, além disso, foram encontradas 5 possiveis áreas de interação proteína-proteína (Figura 10D). Esses dados sugerem que há uma grande chance de que possíveis aminoácidos com características imunogênicas possam interagir com células do sistema imune do hospedeiro, como citado por Gupta (2007).

Os dados do programa sugerem que a localização subcelular da proteína esteja em mitocôndrias em organismos animais, cloroplastos em plantas e no citoplasma em bactérias (Apêndice E), esses dados estão de acordo com os disponíveis sobre a proteína XP_001464106.1 pelo GenBank. 

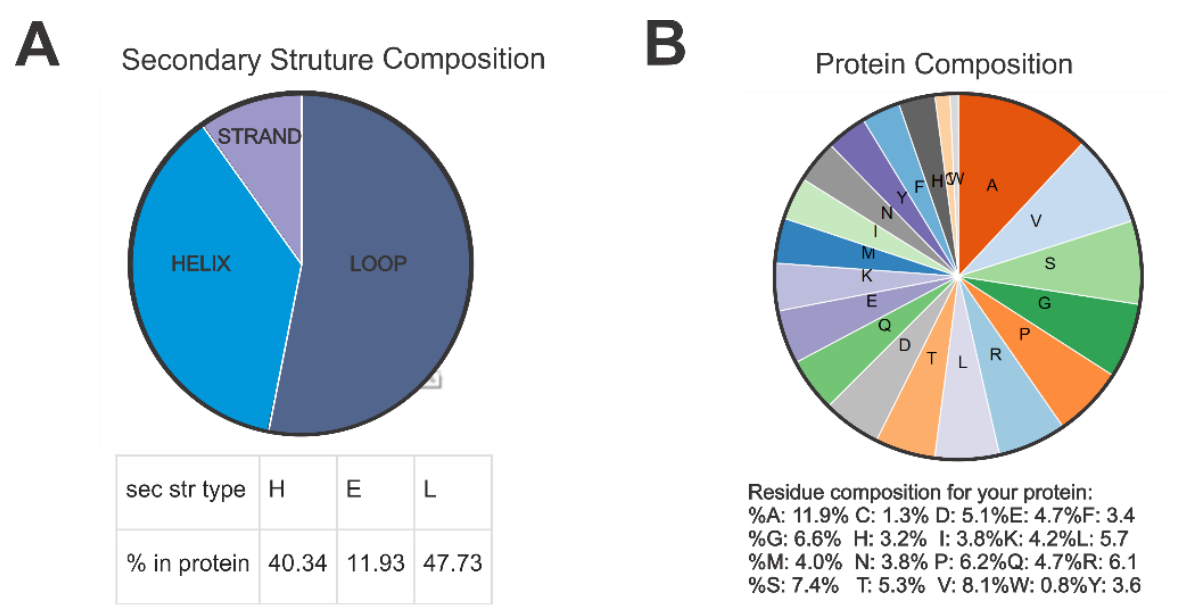

C Predicted solvent accessibility composition (core/surface ratio) for your protein:
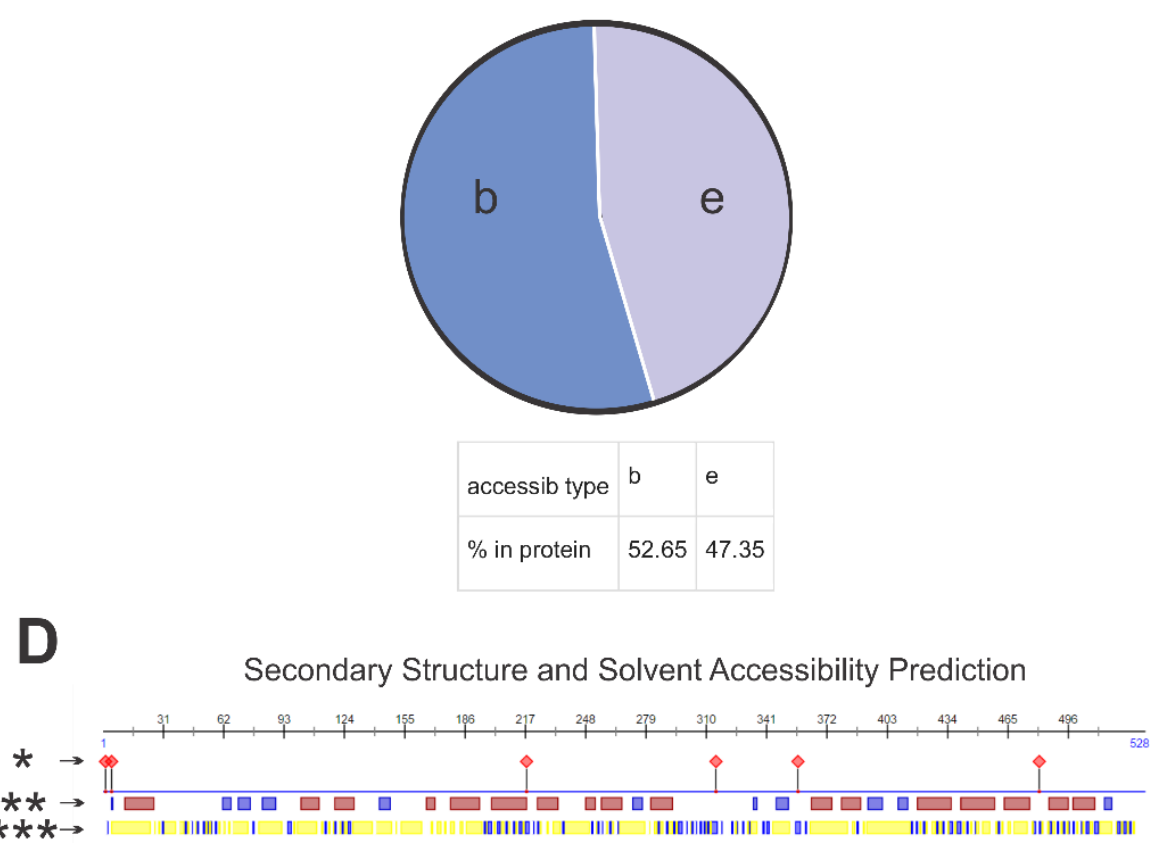

Figura 10: Análise da estrutura físico-química da proteína pela ferramenta PredictProtein. A Composição da estrutura secundaria onde $\mathrm{H}$ : $\alpha$-hélice, $\mathrm{E}$ : folhas- $\beta$ e L: laços. B Composição da estrutura primária. C Acessibilidade dos resíduos de aminoácidos, onde b: resíduos enterrados, e: resíduos com mais de $16 \%$ de sua estrutura voltada para o solvente. D Correlação da sequência proteica com sua estrutura secundaria e pontos de acesso ao solvente, onde * mostra pontos de interação proteína-proteína, ${ }^{* *}$ (PROFsec) correspondem a estrutura secundaria com folhas- $\beta$ (azul) e a-hélices (vermelho) ${ }^{* * *}$ correspondem aos pontos de acesso dos resíduos não expostos ao solvente (amarelo) e expostos ao solvente (azul) da proteína. Os dados foram preditos pelo servidor com uma precisão média acima de $72 \%$

\subsubsection{Análise de epitopos lineares para células B}

De acordo com a literatura, a análise de epitopos para células B são divididas em duas categorias: linear ou não linear. O primeiro consiste em análisar os resíduos de aminoácidos que estão adjacentes um ao outro na sequência primária, enquanto o 
segundo consiste em análisar os resíduos de aminoácidos na forma nativa da proteína que estão separados na estrutura primária, mas, contudo, são postos em proximidade (Bottino e cols, 2013). Neste trabalho não houve possibilidade de identificar epitopos não lineares devido a falta de informações tridimensionais da estrutura da interação MPP-anticorpo e, por essa razão, optamos por identificar epitopos lineares que podem ser preditos por programas.

Utilizando a ferramenta Bepipred v1.0 (Larsen e Nilsen, 2006), preditor de epitopos lineares para células $B$, foram revelados possíveis epitopos lineares para células B (Tabela 2). Para cada aminoácido avaliado pelo servidor foram atribuídos dados e gerados escores de predição. As posições dos epitopos lineares de células B foram previstas para serem localizadas nos resíduos com as pontuações mais altas no escore, usando o ponto de corte de 1.3 ao invés do padrão de 0.35 , uma vez que, de acordo com os Larsen e Nielsen (2006) um ponto de corte de 1.3 confere uma especificidade teórica de $96 \%$ do epitopo, visto que com o ponto de corte padrão de 0.35 confere apenas especificidade teórica de 75\%. Os dados abaixo sugerem 46 resíduos que podem fazer parte de possíveis epitopos lineares para células $B$, com potencial reação a anticorpos em experimentos in vitro.

Tabela 2: Predição de epitopos lineares para células B.

\begin{tabular}{|c|c|c|c|c|c|c|c|}
\hline \# SEQNAME & SOURCE & FEATURE & START & END & SCORE & $\mathrm{N} / \mathrm{A}$ & ? \\
\hline 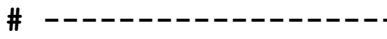 & - & & - & 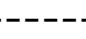 & - & ---- & --- \\
\hline 197501 EMB CBZ & BEPIPRED-1.0B & EPITOPE & 39 & 39 & 1.386 & . & $\mathbf{G} \mid \mathbf{E}$ \\
\hline [_322497501_EMB_CBZ & BEPIPRED-1.0B & EPITOPE & 43 & 43 & 1.821 & . & $\mathbf{R} \mid \mathbf{E}$ \\
\hline [-322497501_EMB_CBZ & BEPIPRED-1. OB & EPITOPE & 44 & 44 & 1.886 & . & $\mathbf{L} \mid \mathrm{E}$ \\
\hline GI_322497501_EMB_CBZ & BEPIPRED-1. OB & EPITOPE & 45 & 45 & 2.027 & - & $P \mid E$ \\
\hline $\mathrm{GI}^{-} 322497501^{-} \mathrm{EMB} \mathrm{CBZ}^{-}$ & BEPIPRED-1.0B & EPITOPE & 46 & 46 & 2.196 & . & $P \mid E$ \\
\hline I_322497501_EMB_CBZ & BEPIPRED-1. OB & EPITOPE & 47 & 47 & 2.319 & . & $\mathbf{G} \mid \mathbf{E}$ \\
\hline$I^{-} 322497501{ }^{-}$EMB_CBZ & BEPIPRED-1.0B & EPITOPE & 48 & 48 & 2.452 & . & $P \mid E$ \\
\hline GI_322497501_EMB_CBZ & BEPIPRED-1. OB & EPITOPE & 49 & 49 & 2.706 & . & $\mathbf{S} \mid \mathbf{E}$ \\
\hline $\mathrm{GI}^{-} 322497501^{-}$EMB_CBZ & BEPIPRED-1.0B & EPITOPE & 50 & 50 & 2.735 & . & $\mathbf{S} \mid \mathbf{E}$ \\
\hline $\mathrm{GI}^{-} 322497501^{-} \mathrm{EMB}{ }^{-} \mathrm{CBZ}$ & BEPIPRED-1. OB & EPITOPE & 51 & 51 & 2.426 & . . & $\mathrm{K} \mid \mathrm{E}$ \\
\hline $\mathrm{GI}^{-} 322497501^{-}$EMB_CBZ & BEPIPRED-1.0B & EPITOPE & 52 & 52 & 2.085 & - & $P \mid E$ \\
\hline GI_322497501_EMB_CBZ & BEPI PRED-1.0B & EPITOPE & 53 & 53 & 1.801 & . & $\mathrm{A} \mid \mathrm{E}$ \\
\hline $\mathrm{GI}^{-} 322497501^{-}$EMB_CBZ & BEPIPRED-1.0B & EPITOPE & 54 & 54 & 1.621 & . & $P \mid E$ \\
\hline $\mathrm{GI}^{-} 322497501^{-} \mathrm{EMB} \mathrm{CBZ}^{-}$ & BEPIPRED-1.0B & EPITOPE & 55 & 55 & 1.391 & . . & $\mathrm{V} \mid \mathrm{E}$ \\
\hline GI_322497501_EMB_CBZ & BEPIPRED-1. OB & EPITOPE & 92 & 92 & 1.475 & . & $A \mid E$ \\
\hline $\mathrm{GI}^{-} 322497501^{-} \mathrm{EMB}{ }^{-} \mathrm{CBZ}$ & BEPIPRED-1.0B & EPITOPE & 93 & 93 & 2.236 & . & $\mathbf{Y} \mid \mathbf{E}$ \\
\hline GI_322497501_EMB_CBZ & BEPI PRED-1.0B & EPITOPE & 94 & 94 & 2.469 & . & $\mathrm{D} \mid \mathrm{E}$ \\
\hline $\mathrm{GI}^{-} 322497501^{-} \mathrm{EMB}{ }^{-} \mathrm{CBZ}$ & BEPIPRED-1.0B & EPITOPE & 95 & 95 & 2.480 & . & $P \mid E$ \\
\hline $\mathrm{GI}^{-} 322497501^{-}$EMB_CBZ & BEPIPRED-1. OB & EPITOPE & 96 & 96 & 2.608 & . & $P \mid E$ \\
\hline GI_322497501_EMB_CBZ & BEPI PRED-1. OB & EPITOPE & 97 & 97 & 2.733 & . . & $S \mid E$ \\
\hline $\mathrm{GI}^{-} 322497501^{-} \mathrm{EMB}{ }^{-} \mathrm{CBZ}$ & BEPIPRED-1.0B & EPITOPE & 98 & 98 & 2.716 & . & $\mathrm{A} \mid \mathrm{E}$ \\
\hline GI_322497501_EMB_CBZ & BEPIPRED-1. OB & EPITOPE & 99 & 99 & 2.276 & . & $P \mid E$ \\
\hline $\mathrm{GI}^{-} 322497501^{-} \mathrm{EMB} \mathrm{CBZ}^{-}$ & BEPIPRED-1.0B & EPITOPE & 100 & 100 & 1.848 & . . & $G \mid E$ \\
\hline GI_322497501_EMB_CBZ & BEPI PRED-1.0B & EPITOPE & 155 & 155 & 1.308 & . . & $\mathrm{S} \mid \mathrm{E}$ \\
\hline $\mathrm{GI}^{-} 322497501^{-}$EMB_CBZ & BEPIPRED-1.0B & EPITOPE & 173 & 173 & 1.318 & . . & $Q \mid E$ \\
\hline GI_322497501_EMB_CBZ & BEPI PRED-1. OB & EPITOPE & 290 & 290 & 1.371 & • & $P \mid E$ \\
\hline GI_322497501_EMB_CBZ & BEPIPRED-1. OB & EPITOPE & 291 & 291 & 1.420 & . & $F \mid E$ \\
\hline
\end{tabular}




\begin{tabular}{|c|c|c|c|c|c|c|c|c|c|}
\hline GI_322497501 & EMB_CBZ & BEPIPRED-1.0B & EPITOPE & 292 & 292 & 1.494 & - & - & $\mathrm{P} \mid \mathrm{E}$ \\
\hline GI_322497501 & EMB_CBZ & BEPI PRED-1.0B & EPITOPE & 293 & 293 & 1.359 & - & - & $\mathrm{H} \mid \mathrm{E}$ \\
\hline 322497501 & EMB_CBZ & BEPIPRED-1.0B & EPITOPE & 296 & 296 & 1.358 & . & . & $\mathbf{S} \mid \mathbf{E}$ \\
\hline 322497501 & EMB CBZ & BEPIPRED-1.0B & EPITOPE & 315 & 315 & 1.345 & . & . & $\mathrm{A} \mid \mathrm{E}$ \\
\hline 322497501 & EMB_CBZ & BEPIPRED-1.0B & EPITOPE & 316 & 316 & 1.383 & . & . & Q|E \\
\hline 322497501 & EMB_CBZ & BEPIPRED-1.0B & EPITOPE & 317 & 317 & 1.352 & . & . & $\mathrm{Y} \mid \mathrm{E}$ \\
\hline GI_322497501 & EMB_CBZ & BEPIPRED-1. OB & EPITOPE & 320 & 320 & 1.369 & . & . & $\mathrm{G} \mid \mathbf{E}$ \\
\hline 322497501 & EMB CBZ & BEPIPRED-1.0B & EPITOPE & 321 & 321 & 1.310 & . & . & $E \mid E$ \\
\hline I_322497501 & EMB_CBZ & BEPI PRED-1. OB & EPITOPE & 322 & 322 & 1.509 & . & - & $\mathbf{R} \mid \mathbf{E}$ \\
\hline 322497501 & EMB_CBZ & BEPIPRED-1. OB & EPITOPE & 323 & 323 & 1.654 & . & . & $\mathrm{H} \mid \mathrm{E}$ \\
\hline GI_322497501 & EMB_CBZ & BEPI PRED-1.0B & EPITOPE & 324 & 324 & 1.668 & . & . & $\mathrm{D} \mid \mathrm{E}$ \\
\hline $\mathrm{GI}^{-} 322497501$ & EMB_CBZ & BEPIPRED-1.0B & EPITOPE & 325 & 325 & 1.574 & - & - & $\mathrm{H} \mid \mathrm{E}$ \\
\hline 322497501 & EMB_CBZ & BEPIPRED-1.0B & EPITOPE & 326 & 326 & 1.451 & - & - & $E \mid E$ \\
\hline 322497501 & EMB_CBZ & BEPIPRED-1.0B & EPITOPE & 335 & 335 & 1.322 & . & . & $\mathrm{K} \mid \mathrm{E}$ \\
\hline 322497501 & EMB_CBZ & BEPI PRED-1. OB & EPITOPE & 336 & 336 & 1.510 & . & . & $\mathrm{P} \mid \mathrm{E}$ \\
\hline GI_322497501 & EMB_CBZ & BEPI PRED-1. OB & EPITOPE & 337 & 337 & 1.912 & $\cdot$ & . & $\mathrm{D} \mid \mathrm{E}$ \\
\hline 322497501 & EMB_CBZ & BEPIPRED-1. OB & EPITOPE & 338 & 338 & 1.999 & - & - & $\mathbf{M} \mid \mathbf{E}$ \\
\hline 322497501 & EMB_CBZ & BEPIPRED-1.0B & EPITOPE & 339 & 339 & 1.560 & . & $\cdot$ & $\mathrm{D} \mid \mathrm{E}$ \\
\hline SI_322497501] & EMB_CBZ & BEPIPRED-1.0B & EPITOPE & 413 & 413 & 1.327 & . & . & $E \mid E$ \\
\hline
\end{tabular}

O ponto de corte usado para definição de um aminoácido dentro de um epitopo foi de 1.3, pela ferramenta BepiPred. Os dados, referentes à coluna indicada por "?" indicam pela letra "E" quando o aminoácido é previsto como sendo parte de um epitopo linear de célula B (pontuação acima do limiar) e "." como sendo região não pertencente a epitopos (pontuação abaixo do limiar). Os dados foram precedidos pelos símbolos de seus respectivos aminoácidos seguida por um '|' (barra vertical). No total 219 aminoácidos foram incluídos em possíveis epitopos lineares para células B, equivalente a $41 \%$ dos aminoácidos da proteína.

Ao correlacionar os dados da Tabela 2 com a Figura 10D, é possível sugerir que parte (12/46) dos possíveis epitopos lineares de células B estão voltados para o solvente ou em estado intermediário (23/46), teoricamente aumentando a probabilidade de reconhecimento antígeno-anticorpo em possíveis ensaios in vitro (Figura 11). Os dados mostraram que a MPP tem potencial para ser reconhecida por células B pois estão situadas em resíduos expostos ao solvente a qual aumenta a chance de interagirem com células do sistema imune e, assim, gerarem anticorpos. Além disso, esses achados sugeriram regiões onde encontramos mais de 4 aminoácidos seguidos a qual aumentam a chance de serem reconhecidos por células $B$ (Bottino e cols, 2013). Outro ponto a ser visto é que a presença de epitopos lineares podem influenciar na especificidade do teste como citado por alguns autores, que relataram que a presença de epitopos lineares nos candidatos a marcadores de diagnóstico podem aumentam sua especificidade para o organismo testado (Gupta, 2007; Menezes-Sousa e cols, 2014).

Além disso na tabela em Apêndice A, teríamos um total de 219 resíduos em zonas de possíveis epitopos lineares para células $B$ usando um ponto de corte padrão de 0.35 , como citado por Larsen e Nilsen (2006). 


\section{Correlação dos pontos de acesso com epitopos}

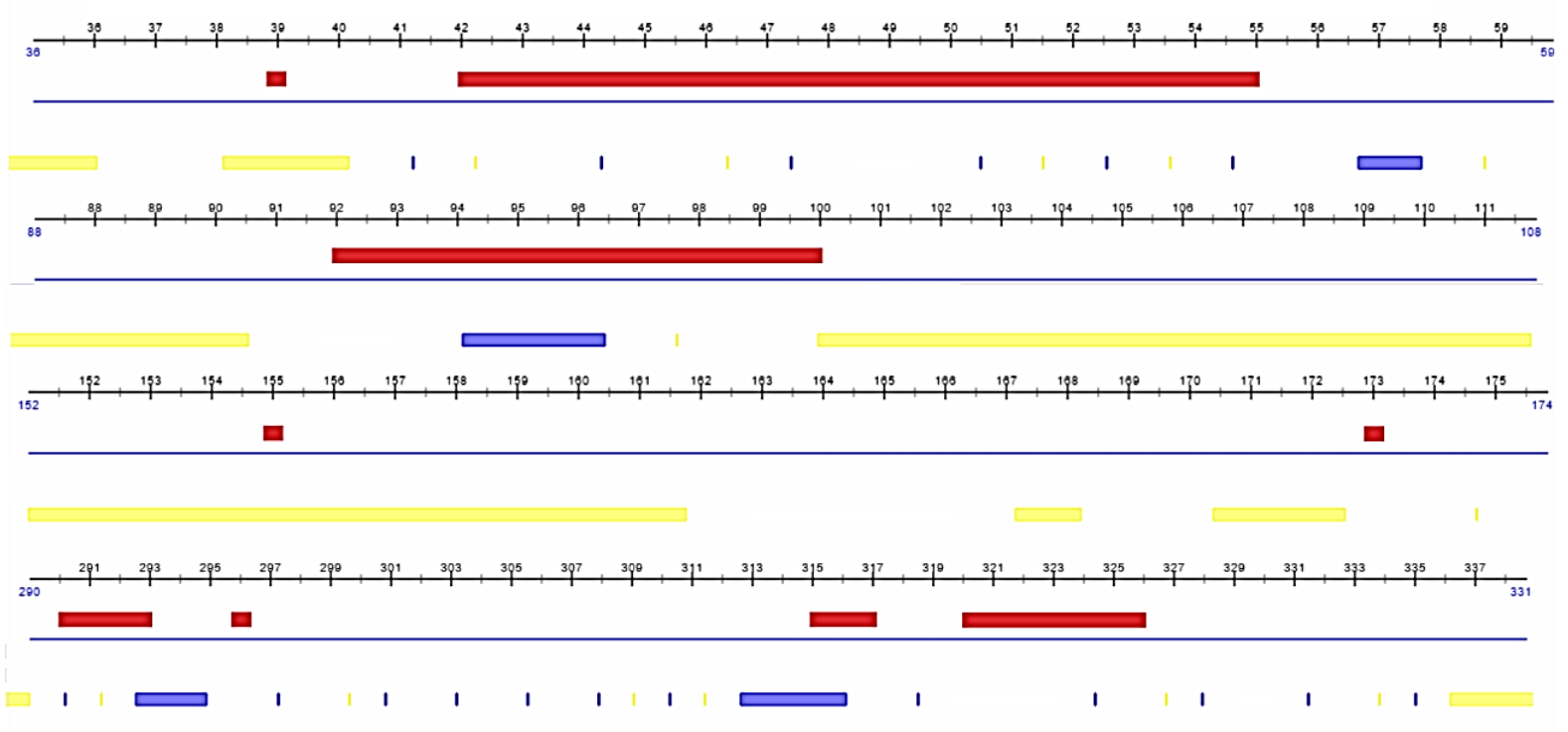

Figura 11: Correlação dos dados do PredictProtein com BepiPred. Pontos de acesso ao solvente dos resíduos expostos ao solvente da proteína em Azul; pontos de acesso enterrados ao solvente da proteína em Amarelo; epitopos sugeridos em vermelho e; área não marcada entre as cores amarelo e azul correspondem a pontos de acesso intermediários.

\subsubsection{Análise de sítios de fosforilação}

Usando a ferramenta NetPhos v2.0 (Bloom e cols, 1999; Johnson, 2009), preditor de potenciais sítios de fosforilação em células eucariotas, foram preditos pelo servidor escores gerados numa escala de 0 - 1, de algumas áreas como possíveis sítios de fosforilação em sequências independentes com uma sensibilidade na faixa de $69 \%$ a $96 \%$ e ponto de corte fixo em 0,5 (Figura 12A). Havendo fosforilação em algum ponto da sequência de aminoácidos da proteína, seja em resíduos de serina, treonina ou tirosina, há possibilidade de afetar vias de sinalização e processos celulares que medeiam metabolismo, transcrição, progressão do ciclo celular, diferenciação, citoesqueleto, movimento celular, e funções imunológicas e a imunogenicidade das proteínas e seus epitopos (Johnson, 2009).

A análise de sítios de fosforilação revelou potenciais fosforilações ao longo da sequência de aminoácidos (Figura 12B), nos resíduos de serina em 13 posições, nos resíduos de treonina em 6 posições e nos resíduos de tirosina em 1 posição. A correlação destes dados com o da Figura 11 sugere que 2 aminoácidos de serina nas posições 49 e 97 seriam fosforilados em áreas de possíveis epitopos lineares para 
células B que se encontram em zonas que estariam com seus pontos de acesso em posição intermediária de acesso ao solvente.

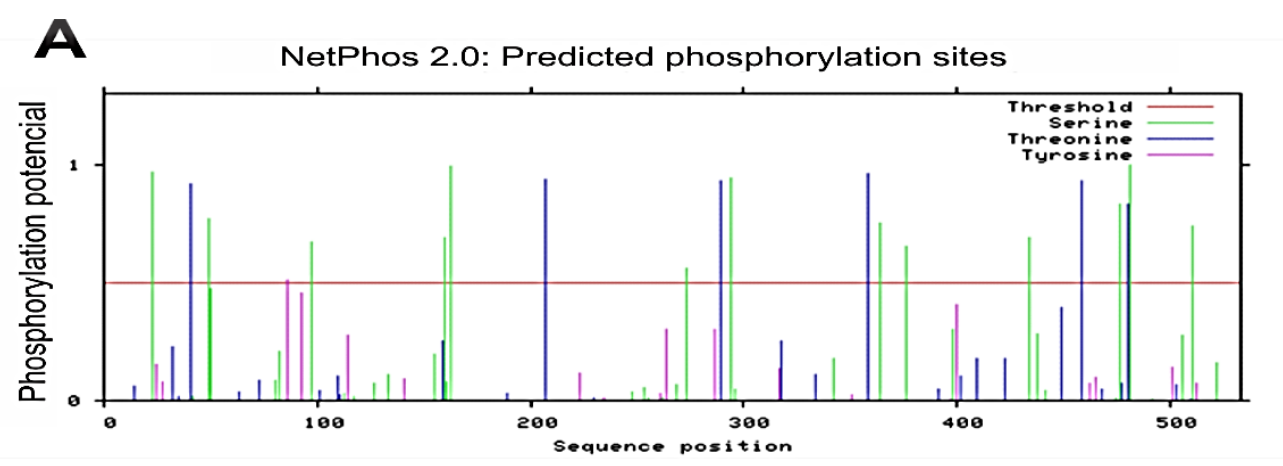

B

Serine predictions

\begin{tabular}{|c|c|c|c|c|}
\hline Name & Pos & $\begin{array}{c}\text { Context } \\
\mathrm{v}\end{array}$ & Score & Pred \\
\hline seq. 1 & 23 & GQARSIYEY & 0.970 & $\star S \star$ \\
\hline seq. 1 & 49 & PPGPSSKPA & 0.773 & $\star S \star$ \\
\hline seq. 1 & 50 & PGPSSKPAP & 0.472 & . \\
\hline seq. 1 & 97 & YDPPSAPGT & 0.671 & $\star S \star$ \\
\hline seq. 1 & 160 & AAPTSSLSQ & 0.689 & $\star S *$ \\
\hline seq. 1 & 163 & TSSLSQRRQ & 0.995 & $\star S *$ \\
\hline $\operatorname{seq} \cdot 1$ & 273 & RVVVSGVNV & 0.559 & $\star S *$ \\
\hline $\operatorname{seq} \cdot 1$ & 294 & PEPHSASAP & 0.943 & $\star S \star$ \\
\hline sea. 1 & 364 & DHAASMVVG & 0.750 & $\star S \star$ \\
\hline seq. 1 & 376 & DIGFSGRMR & 0.652 & $\star S \star$ \\
\hline seq. 1 & 434 & ANKASVADS & 0.688 & $\star S *$ \\
\hline $\operatorname{seq} \cdot 1$ & 476 & VDSDSTLAT & 0.830 & $\star S *$ \\
\hline seq. 1 & 481 & TLATSVEEV & 0.996 & $\star S *$ \\
\hline seq. 1 & 510 & SNKTSLYGH & 0.741 & $\star S *$ \\
\hline
\end{tabular}

Threonine predictions

\begin{tabular}{|c|c|c|c|c|}
\hline Name & Pos & $\begin{array}{c}\text { Context } \\
\mathrm{v}\end{array}$ & score & Pred \\
\hline seq. 1 & 41 & PFGGTSRLP & 0.918 & $\star T \star$ \\
\hline seq. 1 & 207 & RFRDTIDNQ & 0.936 & $\star T \star$ \\
\hline seq. 1 & 289 & EYENTPEPH & 0.929 & $\star \mathrm{T} \star$ \\
\hline seq. 1 & 358 & DRKMTKDHA & 0.962 & $\star \mathrm{T} \star$ \\
\hline seq. 1 & 458 & QNVDTIRDY & 0.928 & $\star \mathrm{T} \star$ \\
\hline seq. 1 & 480 & STLATSVEE & 0.834 & $\star \mathrm{T} \star$ \\
\hline
\end{tabular}

Tyrosine predictions

\begin{tabular}{lcccc} 
Name & Pos & $\begin{array}{c}\text { Context } \\
\text { seq.1 }\end{array}$ & Score & Pred \\
\hline & 86 & SVGAYILAG & 0.511 & ${ }^{\star}{ }^{\star}$ \\
\hline
\end{tabular}

Phosphorylation sites predicted:Ser: 13Thr: 6Tyr: 1

Figura 12: Predição de sítios de fosforilação com a ferramenta NetPhos v2.0. A Gráfico dos possíveis sítios de fosforilação; B Sítios de fosforilação de serina, treonina e tirosina sugeridos pelo servidor.

5.1.4. Análise de sítios de glicosilação

Usando a ferramenta GlycoEP (Chauhan e cols, 2013), preditor de sítios de glicosilação para proteínas de organismos eucariotos, o servidor atribui um escore ao 
aminoácido (Figura 13A) baseado na similaridade de $40-60 \%$ com dados de outras proteínas glicosiladas, com ponto de corte padrão de 0.0 . Os aminoaciados são preditos como glicosídicos ligados a N-,O- e C-. Foi utilizado a ferramenta YinOYang v1.2 (GUPTA, 2001, 2002), para predição de O-ß-glicosilações, esta ferramenta atribui dados numa escala de a 0 a 1 com ponto de corte fixo de 0.5 . O preditor YinOYang encontrou possíveis O-beta-glicosilações em 18 resíduos de treonina e serina (Figura 13B). O GlycoEP revelou 3 resíduos com potenciais $\mathrm{N}$-glicosilações (Figura 13C).

De acordo com Chauhan e cols, (2013), havendo modificações póstraducionais por glicosilações na proteína, diversas funções biológicas podem ser afetadas, como: forma da proteína / manutenção da estrutura, regulação da forma (dobra) de proteínas, rigidez da membrana plasmatica, atividades enzimáticas, na imunogenicidade, na antigenicidade, na patogenicidade e no papel das interações antífeno-hospedeiro.

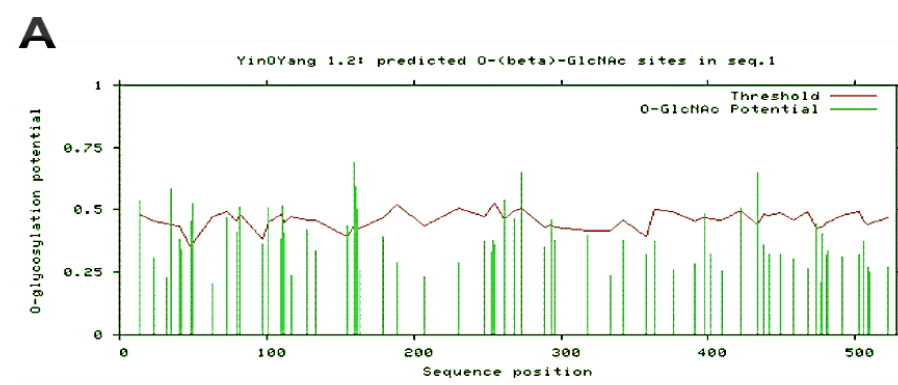

B

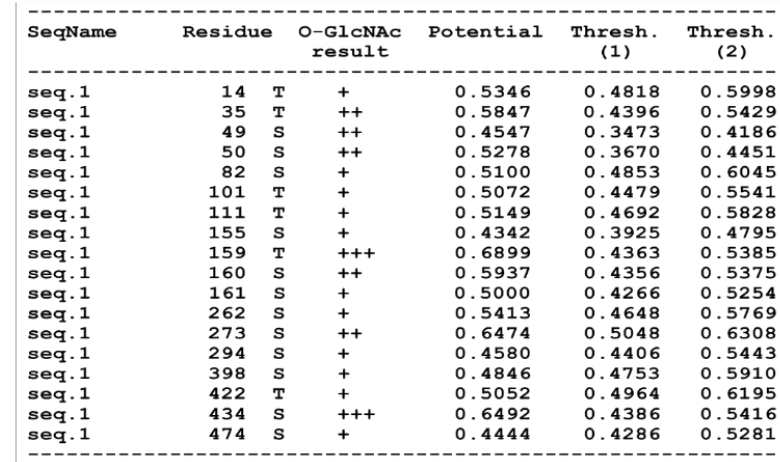

C

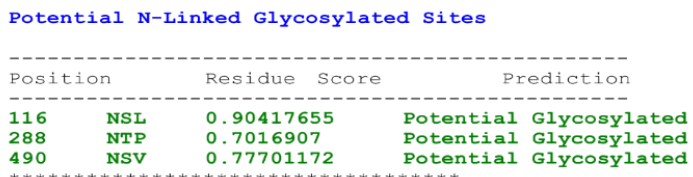

Figura 13: Predição de sítios de glicosilação com as ferramentas GlycoEP e YinOYang v1.2. A Gráfico dos possíveis sítios de glicosilação pelo servidor YinOYang. B Sítios de glicosilação de serina, treonina sugeridos pelo servidor YinOYang. C Sitos de glicosilação sugeridos pelo servidor GlycoEP. 
O GlycoEP também não detectou O-, e C-glicosilações. A análise comparativa entre os dados de fosforilação e glicosilação revelaram 3 possíveis zonas em comuns (Apêndice G). Ao correlacionar os dados adquiridos nas demais predições, encontramos zonas em comum de glicositios nas regiões preditas de epitopos lineares para células $B$ majoritariamente em áreas de acesso intermediário ao solvente (Apêndice G).

Ao correlacionar os dados das predições com os alinhamentos entre tripanossomatídeos (Figura 14) encontramos zonas em comum que podem indicar possíveis reações cruzadas em testes de imunodiagnóstico entre as Leishmanias, contudo, muitas dessas zonas com determinantes imunogênicos não são mantidos em $T$. cruzi o que pode sugerir que a MPP não reaja a soros sensibilizados ao $T$. cruzi. Outro fato a ser visto são os aminoácidos que tiveram determinantes imunogênicos em comum, o que sugere que fosforilações e glicosilações possam atuar como haptenos e, assim, aumentar a imunogênicidade do resíduo a qual estão ligados (Gribben e cols, 1990; Johnson, 2009; Chauhan e cols, 2013). Outro fato a ser visto é que a aquisição da rMPP poderá mostrar em ensaios preliminares in vitro se haverá reações cruzadas com outros organismos que comumente são reconhecidos para testes sorológicos em cães, como Ehrlichia canis e Babesia, e em humanos, como $T$. cruzi (Krawczak e cols, 2015; Ruithe e cols, 2016). Além disso, as áreas de maior potencial imunogênico poderão ser usadas para criar quimeras, fato já visto na literatura que combinaram áreas de maior imunogenicidade entre uma ou mais proteínas e que resultaram no aumento de sua sensibilidade e especificidade do teste (Bottino e cols, 2013; Ruithe e cols, 2016), como visto nos trabalhos de Soto e cols (1998) e de Rosati e cols (2001) que conseguiram uma sensibilidade de $73-93 \%$ e especificidade de $96-100 \%$. 


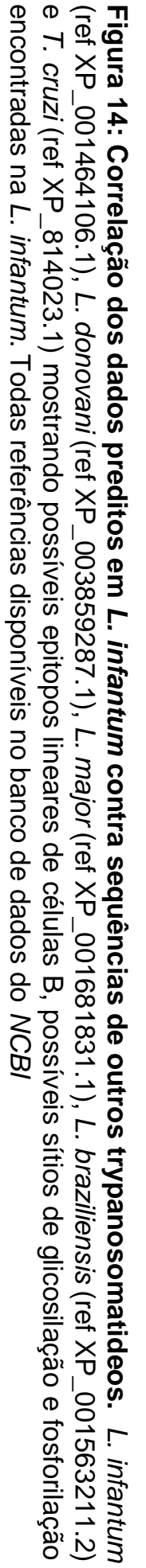
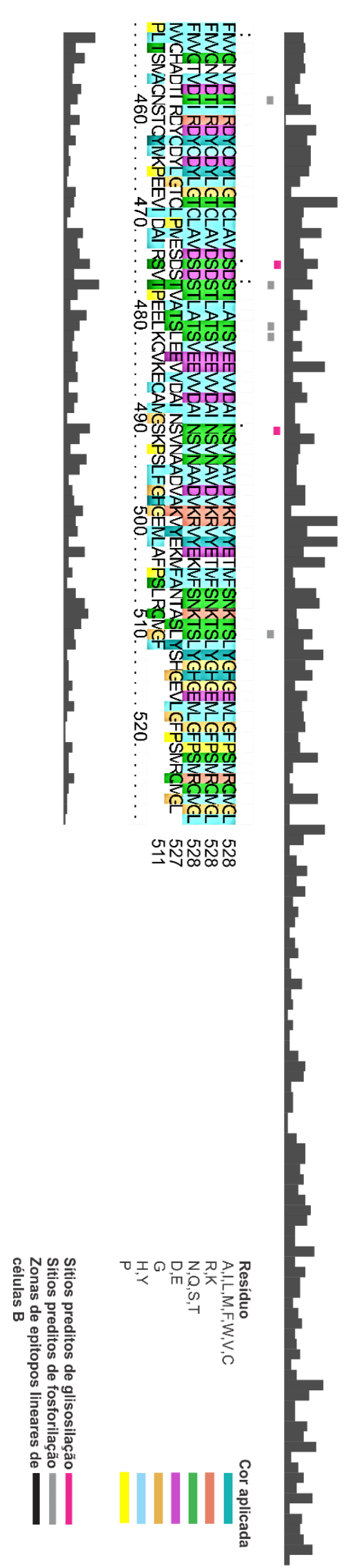
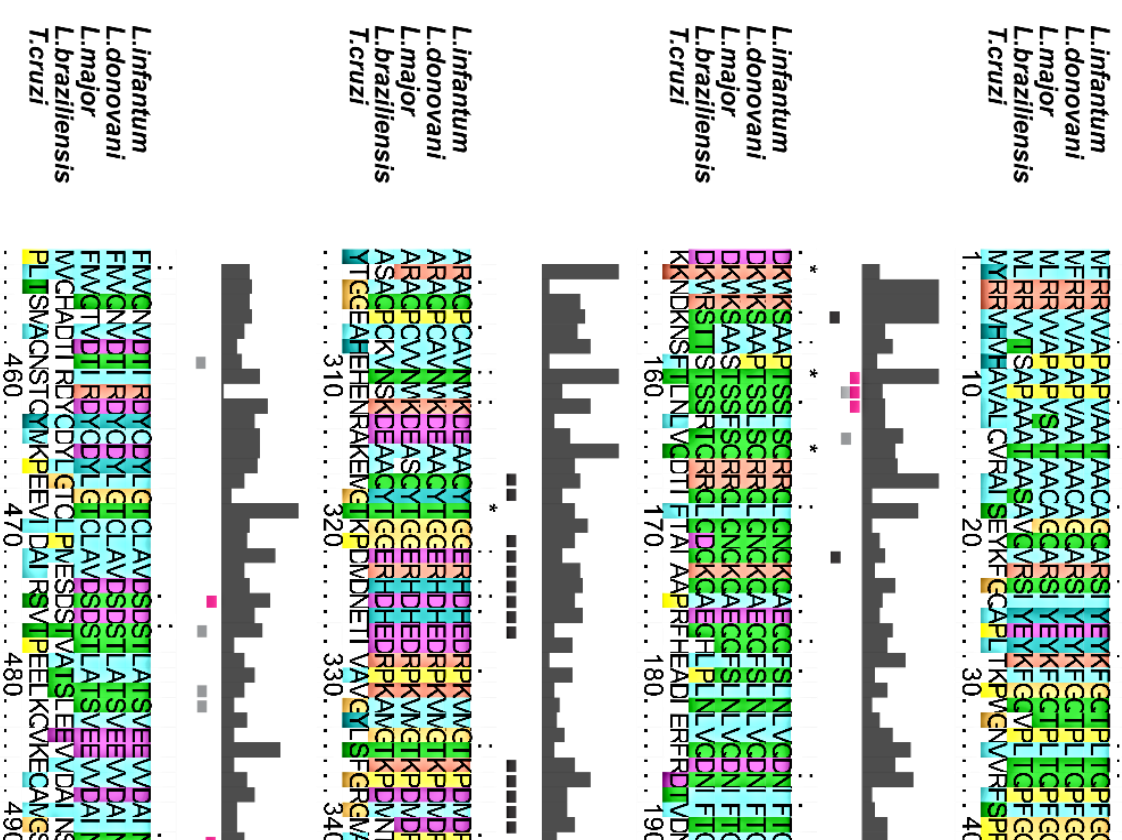

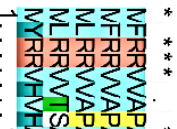

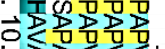

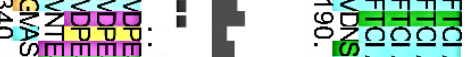
:

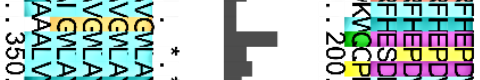
. 4 भत्रफलफल

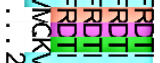
: 唋主 : 그므므르

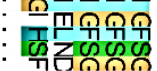

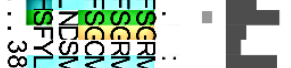

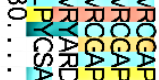

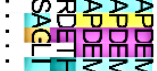

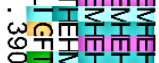

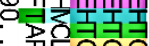
쟁ำ 罗变界界界

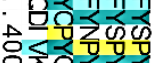
웃ㄱㅁำ

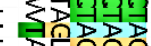

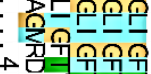

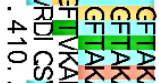

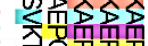

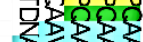

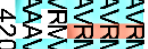

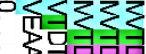
숫추소속

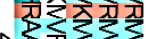

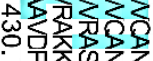

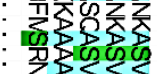

设结

四丝员贫 o ग050

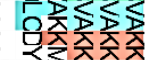

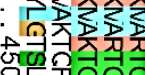
벙벙벙벙듕

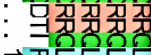
굮ํํํำ

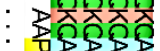
: 崹监监而 监呵们

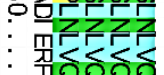

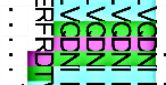
血婴婴婴罚. 싳므믈

: 薀盛盛

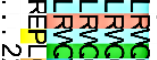
스ำำดิ : 员而而而:

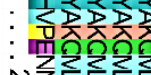

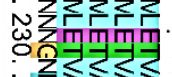

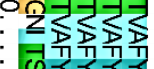

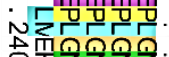

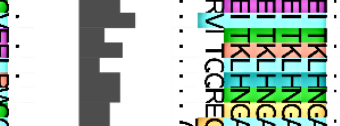

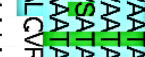

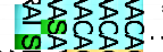

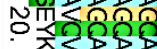

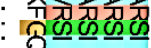
: 贺血而而

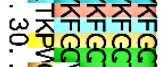

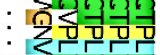
: 새꾺ํํำ

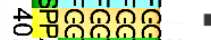
:

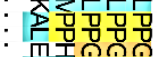

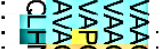

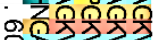
调分部离

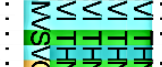

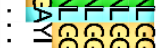
क्षितिर

: गुफ्रफक्त : र्री : 产然. 的领解

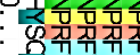

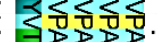
Nmenक ज记 : 트트응.

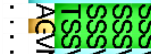

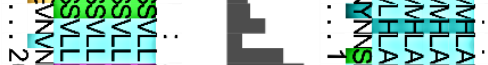

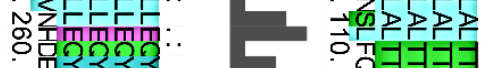
:

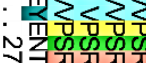

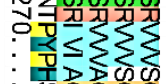

: प्रिम्क्रफ

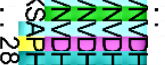

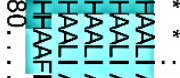

忟而而而而

v部血血 옦ㄲㄲㄲㄲㄲㄲ

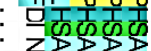
उon

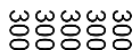

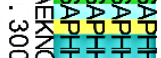




\subsection{Reação de Polimerização em Cadeia (PCR)}

A estratégia de realizar a análise preliminar in silico para depois tomar a decisão de prosseguir para testes in vitro foi citada por vários trabalhos que tiveram o intuito de encontrar marcadores de diagnóstico de parasitos (Faria, 2010; Carvalho e cols, 2011; Lima e cols, 2016). Após a análise in silico decidimos que a MPP teria qualidades imunogênicas para prosseguir para testes in vitro, com isso, desenhamos os primers que amplificariam a região do gene que codifica a MPP (Tabela 1) e realizamos as reações de amplificação utilizando amostra de DNA total de Leishmania chagasi. A padronização dos primers (Figura 15A e Apêndice $H$ ) foi conduzida segundo a metodologia de Taguchi, citada por Viljoen e cols (2005).

Os resultados da padronização apontaram que a reação I como insatisfatória devido à grande formação de dímeros de primers indicado pela seta vermelha na Figura 15A (Viljoen e cols, 2005). A reação II (Figura 15B) foi apontada como satisfatória, apresentando um bom sinal de banda e sem sinal de formação de dímeros, a temperatura considerada ótima para a reação foi de $65^{\circ} \mathrm{C}$ encontrada no produto com melhor sinal de banda. De acordo com a literatura, a padronização da reação de PCR é necessária para evitar a formação de dímeros de primers que poderiam interferir em reações de ligação enzimática entre produto da reação de PCR com vetor de clonagem (Viljoen e cols, 2005).

Os amplicons de número 5 da Figura 15B e de número 5 do Apêndice $\mathbf{H}$ foram selecionados para serem ligados através da ação da enzima ligase ao vetor pGEM-T easy, conforme $o$ item 4.5. A transformação e seleção bacterianas foram realizadas de acordo com os itens 4.5.2 e 4.5.3. O DNA plasmidial foi extraído como indicado no item 4.5.4. 


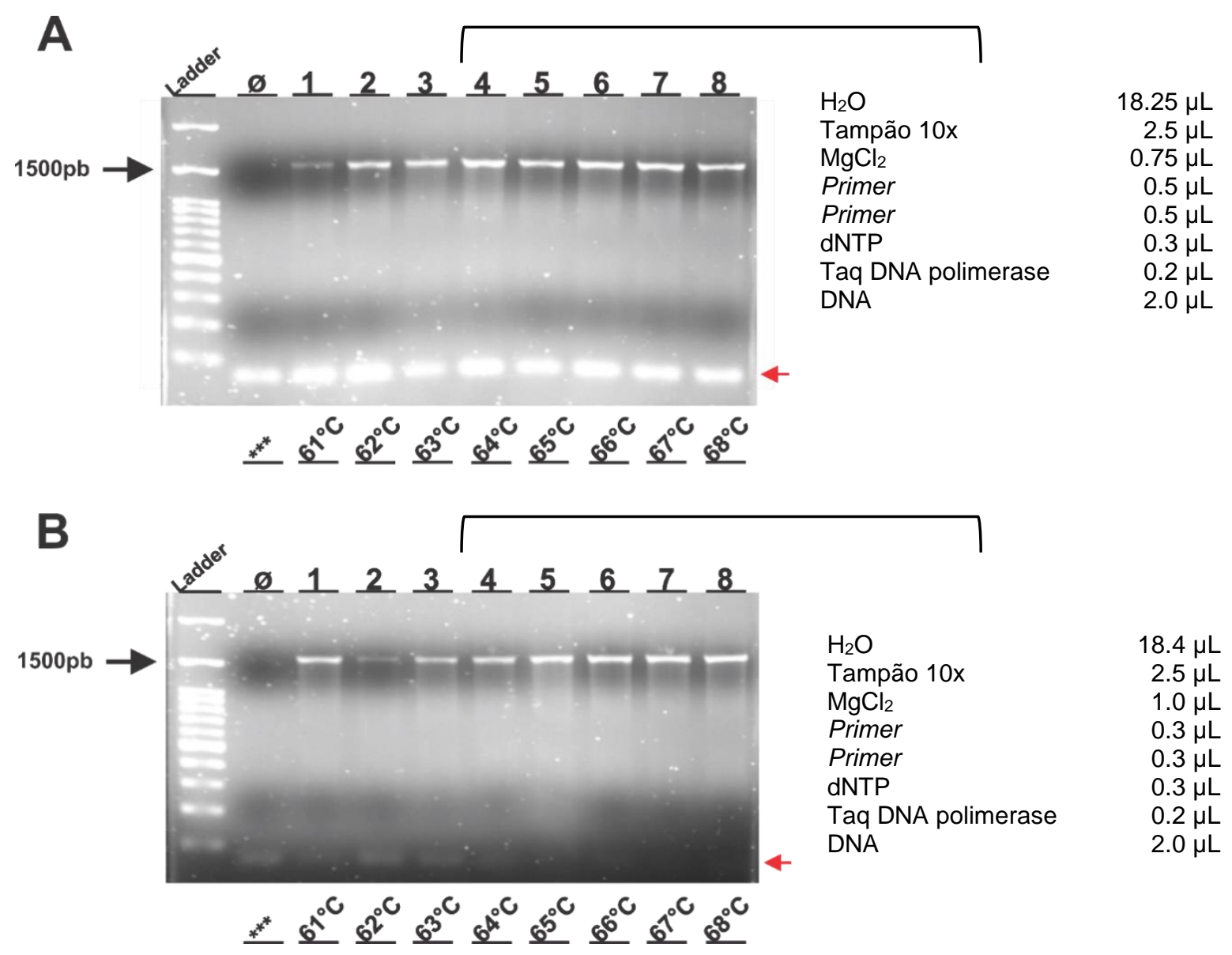

Figura 15: Imagem da padronização das PCRs do gene LDBPK_130760 usando os primers LC01/02 em gel de agarose a $0,8 \%$. Reações de PCR em diferentes temperaturas de anelamento e concentrações de reagentes em A (reação I) e B (reação II). Controle Negativo, uso de $2 \mu \mathrm{L}$ de $\mathrm{H}_{2} \mathrm{O}$ tridestilada (ø); produtos das reações I e II (1-8) e; Marcador de peso molelcular (Ladder) de 100pb Kasvi. Seta preta indicando banda de altura de $1500 \mathrm{pb}$. Seta vermelha mostrando resquícios de componentes da reação de PCR.

Para confirmar a presença do gene inserido na após extração plasmidial, foi realizada PCR usando $1 \mu \mathrm{L}$ de DNA plasmidial com os primers respectivos para validar a presença do gene de interesse, como mostram as Figura 16A e Apêndice H. Com isso, os clones foram selecionados e alíquotados, de acordo com o item 4.7, para serem sequenciados. 


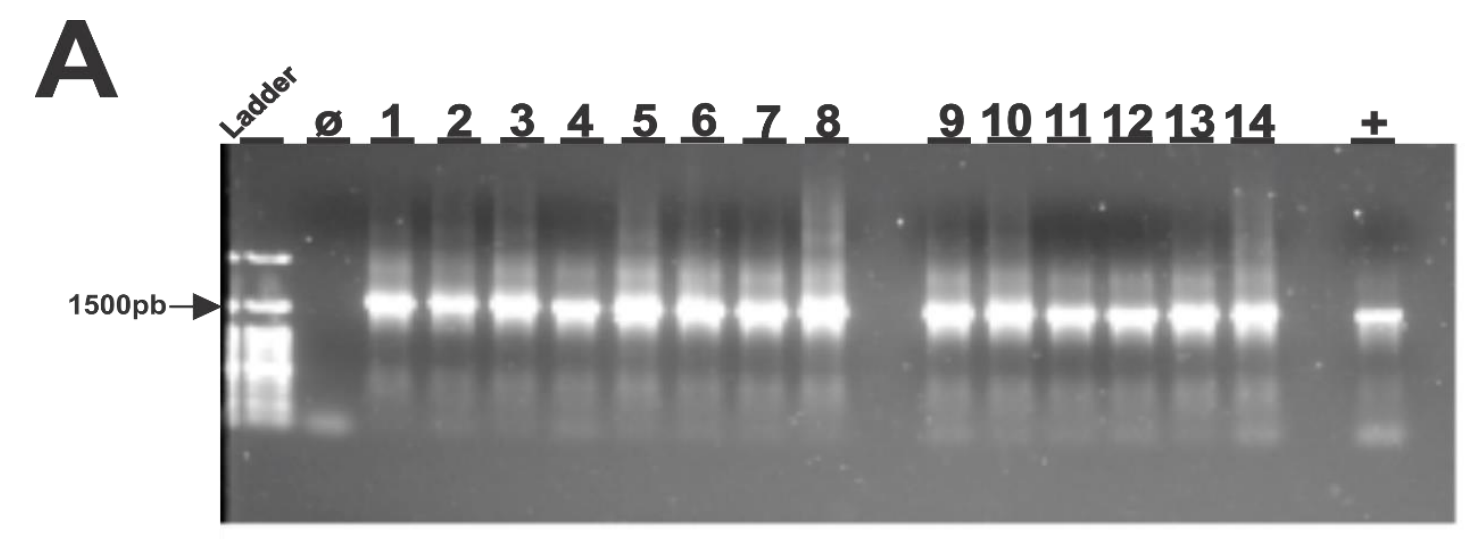

Figura 16: Análise em gel de agarose da presença do gene LDBPK_130760 no DNA plasmidial extraído. A Análise molecular por PCR do DNA plasmidial extraído. Marcador de peso molelcular (Ladder) de 100pb kasvi; Controle Negativo, uso de $2 \mu \mathrm{L}$ de $\mathrm{H}_{2} \mathrm{O}$ tri-destilada ø, clones 1-14, controle positivo (+) DNA total de Leishmania donovani. Seta preta indicando banda de 1500pb. Gel de agarose a $0,8 \%$.

\subsection{Análise do Sequenciamento}

Dos 16 clones enviados para sequenciamento, aproximadamente $40,9 \%$ deles apresentaram uma baixa qualidade do sequenciamento e foram descartadas devido à impossibilidade de identificar a sequência de DNA amplificada. Cerca de 59,1\% foram alinhados com sequências contidas no banco de dados GenBank/NCBI para identificar a identidade das sequências inseridas nos clones.

A análise do alinhamento das sequências pelas ferramentas Clustal $\mathrm{O}$ e SnapGene permitiram identificar as sequências que tiveram inserções, deleções ou trocas de bases, dessa forma, as sequências que tiveram mutações que alterariam na codificação do padrão de aminoácidos pertencentes à proteína foram removidas. A Figura 17A mostra sequências alinhadas com o banco de dados GenBank/NCBI e seus respectivos valores de E-value e similaridade, identificados na análise pela ferramenta BLASTn. Os valores de similaridade mostraram-se significativos, sendo que 17/32 sequências apresentaram valores de identidade de $99 \%$ nas áreas reconhecidas como DNA de Leishmania donovani. O tamanho médio das sequências dos clones foram de $655 \mathrm{nts}$, sendo que o maior corresponde a $901 \mathrm{nts}$ e o menor de 140 nts. 


\begin{tabular}{|c|c|c|c|}
\hline \multicolumn{4}{|c|}{$\begin{array}{l}\text { Leishmania donovani mitochondrial processing peptidase alpha subunit, putative (LDBPK_130760) mRNA, complete cds } \\
\text { Sequence ID: ref|XM_003859239.1|Length: 1587Number of Matches: } 1\end{array}$} \\
\hline Expect & Identities & Gaps & Strand \\
\hline 671 bits(363) $\quad 0.0$ & $366 / 367(99 \%)$ & $1 / 367(0 \%)$ & Plus/Plus \\
\hline \multicolumn{4}{|c|}{$\begin{array}{l}\text { Leishmania donovani mitochondrial processing peptidase alpha subunit, putative (LDBPK_130760) mRNA, complete cds } \\
\text { Sequence ID: ref|XM_003859239.1|Length: } 1587 \text { Number of Matches: } 1\end{array}$} \\
\hline Expect & Identities & Gaps & Strand \\
\hline 1057 bits(572 )0.0 & $586 / 592(99 \%)$ & $4 / 592(0 \%)$ & Plus/Plus \\
\hline \multicolumn{4}{|c|}{$\begin{array}{l}\text { Leishmania donovani mitochondrial processing peptidase alpha subunit, putative (LDBPK_130760) mRNA, complete cds } \\
\text { Sequence ID: ref|XM_003859239.1|Length: } 1587 \text { Number of Matches: } 1\end{array}$} \\
\hline Expect & Identities & Gaps & Strand \\
\hline 1413 bits(765) 0.0 & 767/768(99\%) & $0 / 768(0 \%)$ & Plus/Plus \\
\hline
\end{tabular}

\section{B}

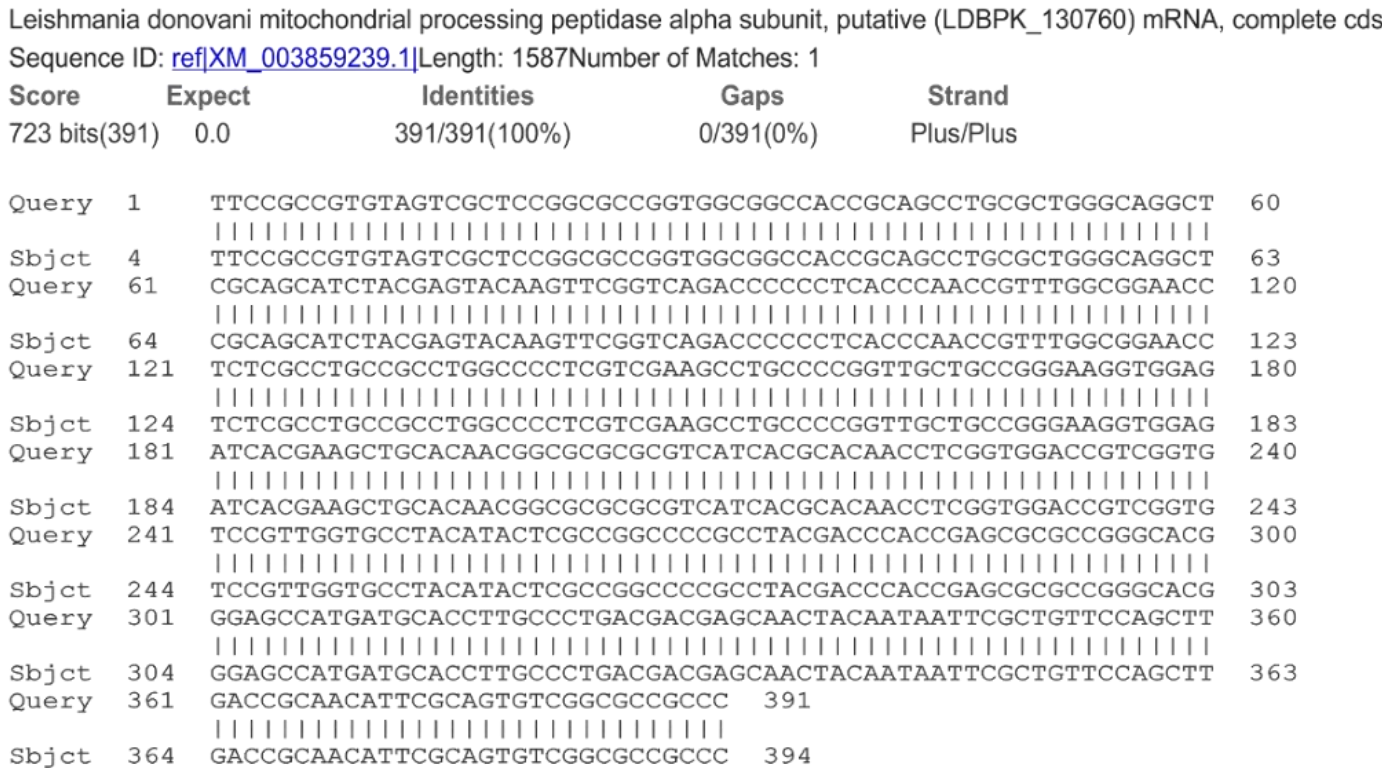

Figura 17: Análise do sequenciamento dos clones. A Análise por BLASTn (GenBank/NCBI) com destaque para os valores de $E$-value, identidade e lacunas (Gaps) para cada um dos trechos do DNA. B Alinhamento do clone 05 com o servidor de dados BLASTn (GenBank/NCBI), utilizando o hit de maior escore encontrado.

Os clones de número 5 (primers LC01/02 - Figura 16A) e 13 (primers LC10/11 - Apêndice H) foram eleitos para serem submetidos a midprep, conforme item 4.5.4, devido ao alto escore obtido e continham mínimas alterações nucleotídicas que não resultariam na troca de aminoácidos. Sequências com mutações do tipo inserção ou mutação foram descartadas, uma vez que tais alterações poderiam gerar alterações na fase de leitura do gene, alterando bastante a estrutura primaria da proteína a ser gerada. 


\subsection{Expressão de proteína em sistema procarioto}

Previamente à expressão de proteínas, foi realizada análise molecular por PCR para verificar a presença do gene que codifica a proteína XP_001464106.1 em bactérias $E$. coli da linhagem Rosetta usando 1 uL da bactéria cultivada e submetido a análise eletroforética em gel de agarose (Figura 18). Em base do resultado da PCR, elegemos um dos clones, sendo eleito o de número 6 , para prosseguir o experimento e, por conseguinte, o modelo procarioto foi submetido a expressão de proteínas por indução de IPTG. Os resultados do SDS-PAGE (Figura 19A) mostraram a proteína sendo expressa em uma relação de indução por tempo no sistema procarioto.

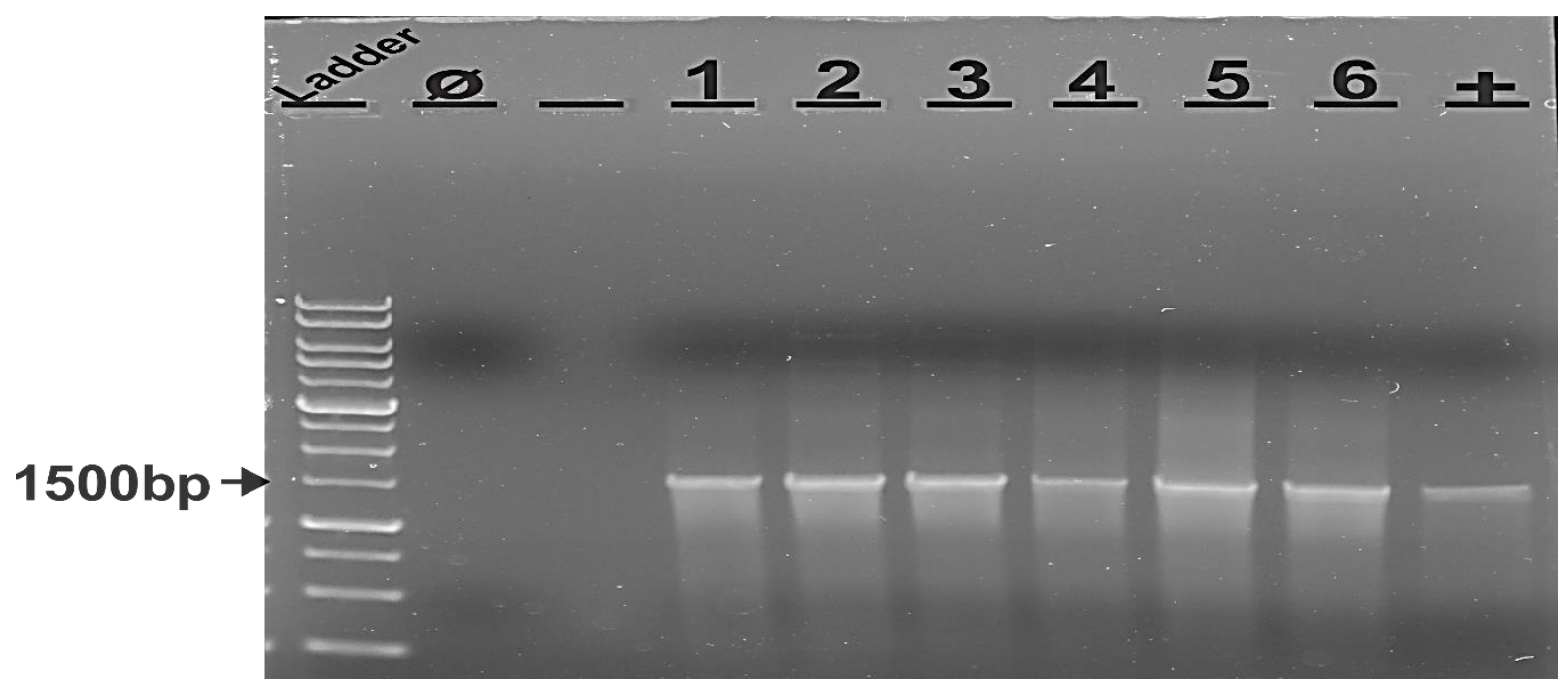

Figura 18: Verificação da presença do gene LDBPK_130760 no vetor de expressão após transformação bacteriana. Análise molecular usando primers LC10/LC11. Marcador de peso molelcular (Ladder) de1Kb Kasvi, ø Controle Negativo, 1-6 Clones e + Controle Positivo (DNA genômico).

$\mathrm{Na}$ mesma figura, é possível sugerir que a proteína é encontrada majoritariamente nas membranas e não secretada, quando comparada as amostras contendo somente sobrenadante. Na Figura 19B, ao analisar as amostras sonicadas, verifica-se sua solubilidade. Comparando as amostras, vimos que a proteína se encontram majoritariamente no extrato insolúvel a qual acreditamos estar correlacionado a formação de corpos de inclusão 

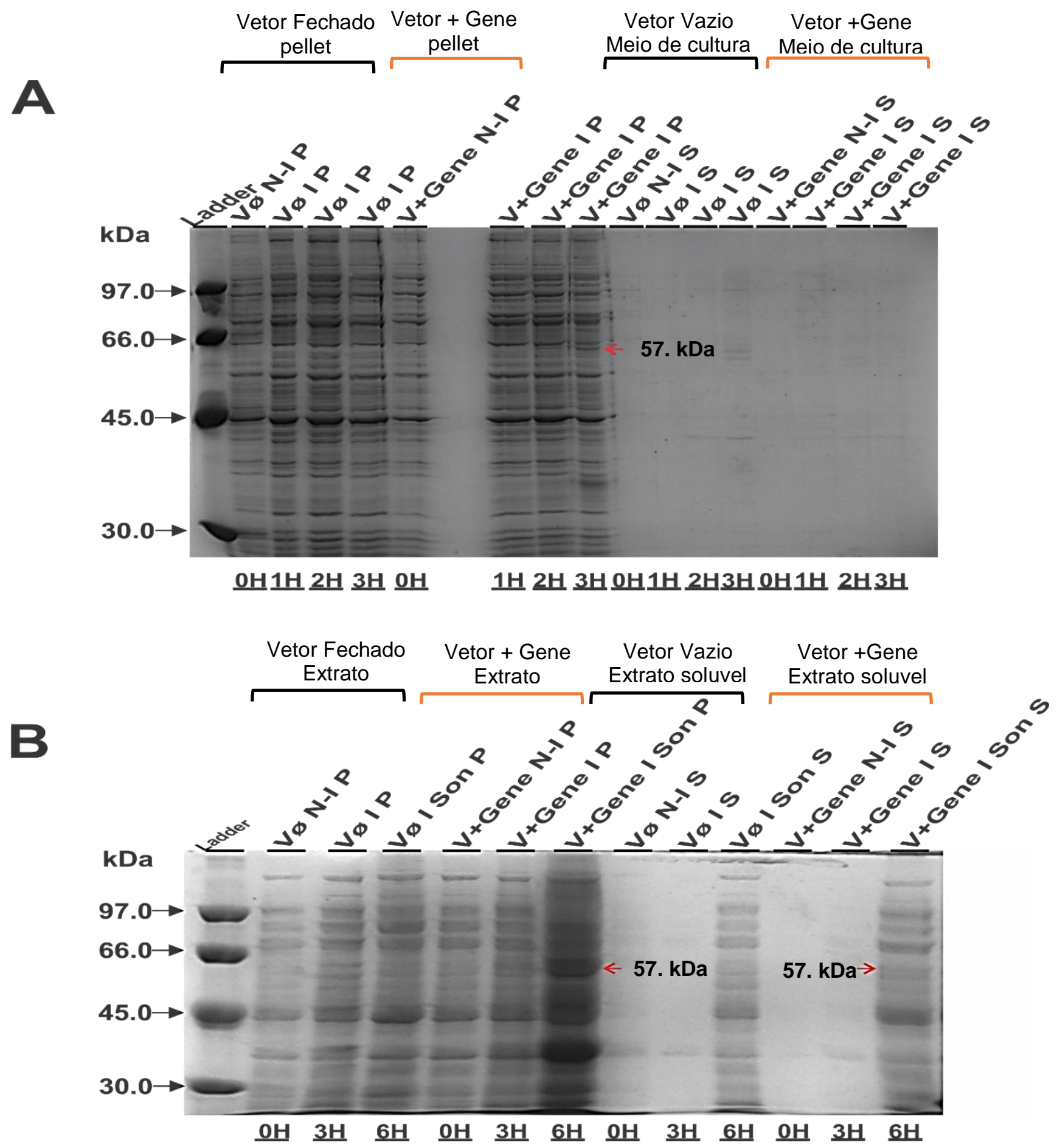

Figura 19: Análise da expressão da rMPP em sistema procarioto em escala de tempo por indução de IPTG no meio de cultura e análise de solubilidade após sonicação. A Análise por SDS-PAGE relação bactérias induzidas por IPTG $\times$ Tempo. B Relação bactérias não sonicadas $x$ sonicadas. Marcador de baixo peso molecular - Amersham (Ladder), vetor fechado não induzido pellet (Vø N-I P), vetor fechado induzido pellet ( $(\varnothing \varnothing \mid P)$, vetor fechado induzido sonicado pellet (Vø I Son $P$ ), vetor ligado ao gene não induzido pellet $(\mathrm{V}+\mathrm{Gene} \mathrm{N}-\mathrm{I} P)$, vetor ligado ao gene induzido pellet $(\mathrm{V}+\mathrm{Gene}$ I $\mathrm{P})$, vetor ligado ao gene induzido sonicado pellet ( $\mathrm{V}+\mathrm{Gene}$ I Son $\mathrm{P})$, vetor fechado não induzido sobrenadante (Vø N-I S), vetor fechado induzido sobrenadante (Vø I S), vetor fechado induzido sonicado sobrenadante (Vø I Son S), vetor ligado ao gene não induzido sobrenadante (V+Gene N-I S), vetor ligado ao gene induzido sobrenadante $(\mathrm{V}+\mathrm{Gene}$ I $\mathrm{S})$, vetor ligado ao gene induzido sonicado sobrenadante (V+Gene I Son S). Seta vermelha indicando proteína de estudo. 
O clone de numero 6 (Figura 18) foi cultivado e, posteriormente, foi submetido ao processo de purificação, conforme o item 4.11. A análise das fases da purificação da rMPP (Figura 20) indicou que ocorria o enriquecimento (aumento da concentração) da proteína heteróloga durante o processo de purificação e, também, verificou-se que outras proteínas oriundas da bactéria estavam presentes no purificado, estas teriam em sua composição resíduos de histidina que foram retidos pela matriz de zinco usada pelo método de purificação por cromatografia de afinidade (Bornhorst e Falke, 2000; Gräslund e cols, 2008) e, a presença destas proteínas poderiam influenciar os resultados de outros ensaios, como no preparo das placas de ELISA ou, ate mesmo, nos testes sorológicos.

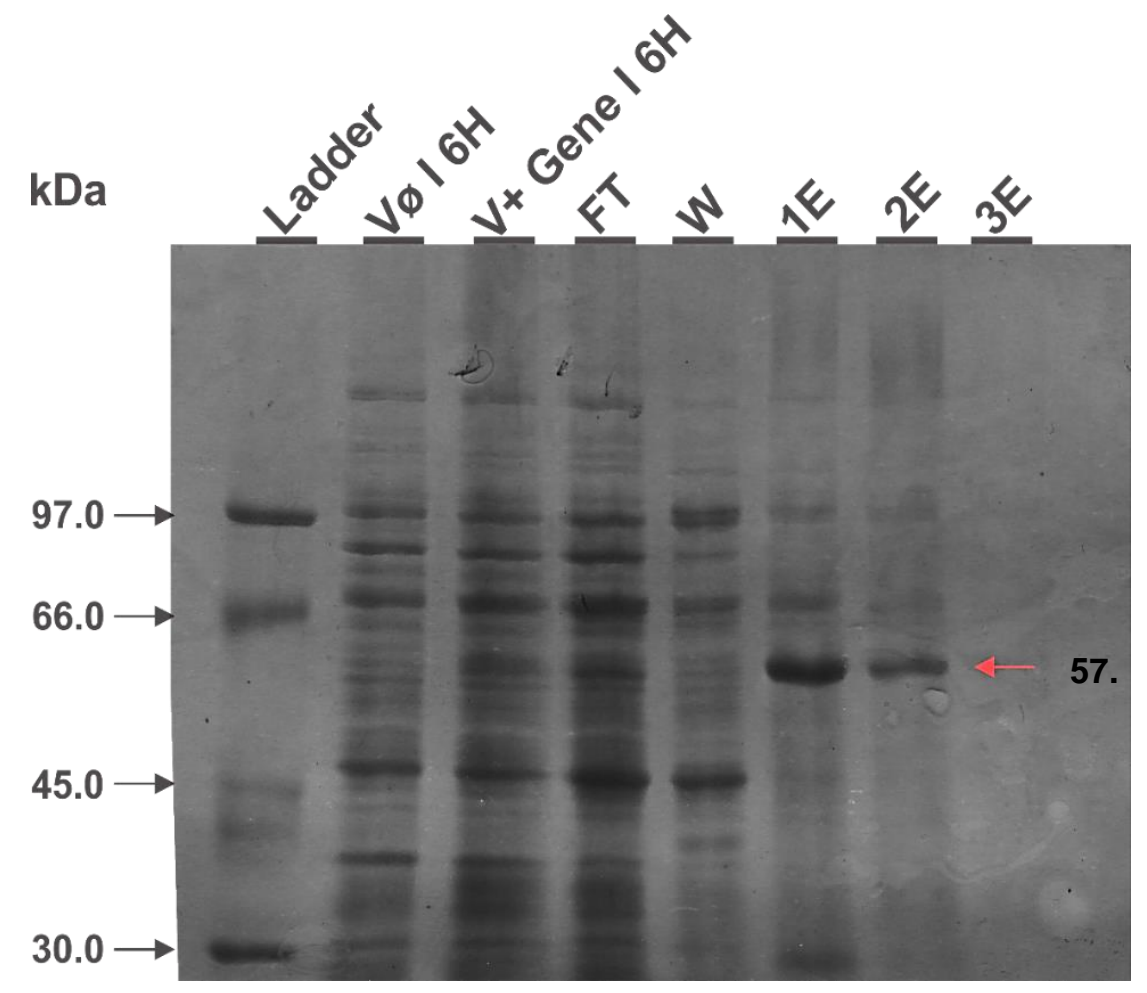

Figura 20: Etapas da purificação da rMPP do extrato insolúvel do sistema procarioto. Análise das etapas da purificação por SDS-PAGE. Marcador de peso molelcular (Ladder) Amersham de $97 \mathrm{kDa}$; vetor fechado induzido 6 horas (Vø I P 6H), vetor + Gene induzido 6 horas (V+ Gene I 6H); Flow trhough (FT), Wash (W); 1E Primeira eluição; 2E Segunda eluição e 3E Terceira eluição.

O resultado do imuno blotting com anticorpo anti-His Tag (Figura 21) detectou proteínas com pesos moleculares próximos ao esperado de $57.656 \mathrm{kDa}$, foram especuladas que as bandas próximos a $60 \mathrm{kDa}$ seriam a rMPP, uma vez que a essa proteína recebeu a adição da calda de histidina e, devido a isso, poderia ter 
aumentado a massa da rMPP. Na mesma imagem, encontramos diferentes bandeamentos de menor massa que a rMPP, que de acordo com Mahmood e Yang (2012), seriam proteínas degradas que geraram produtos de tamanhos variados.

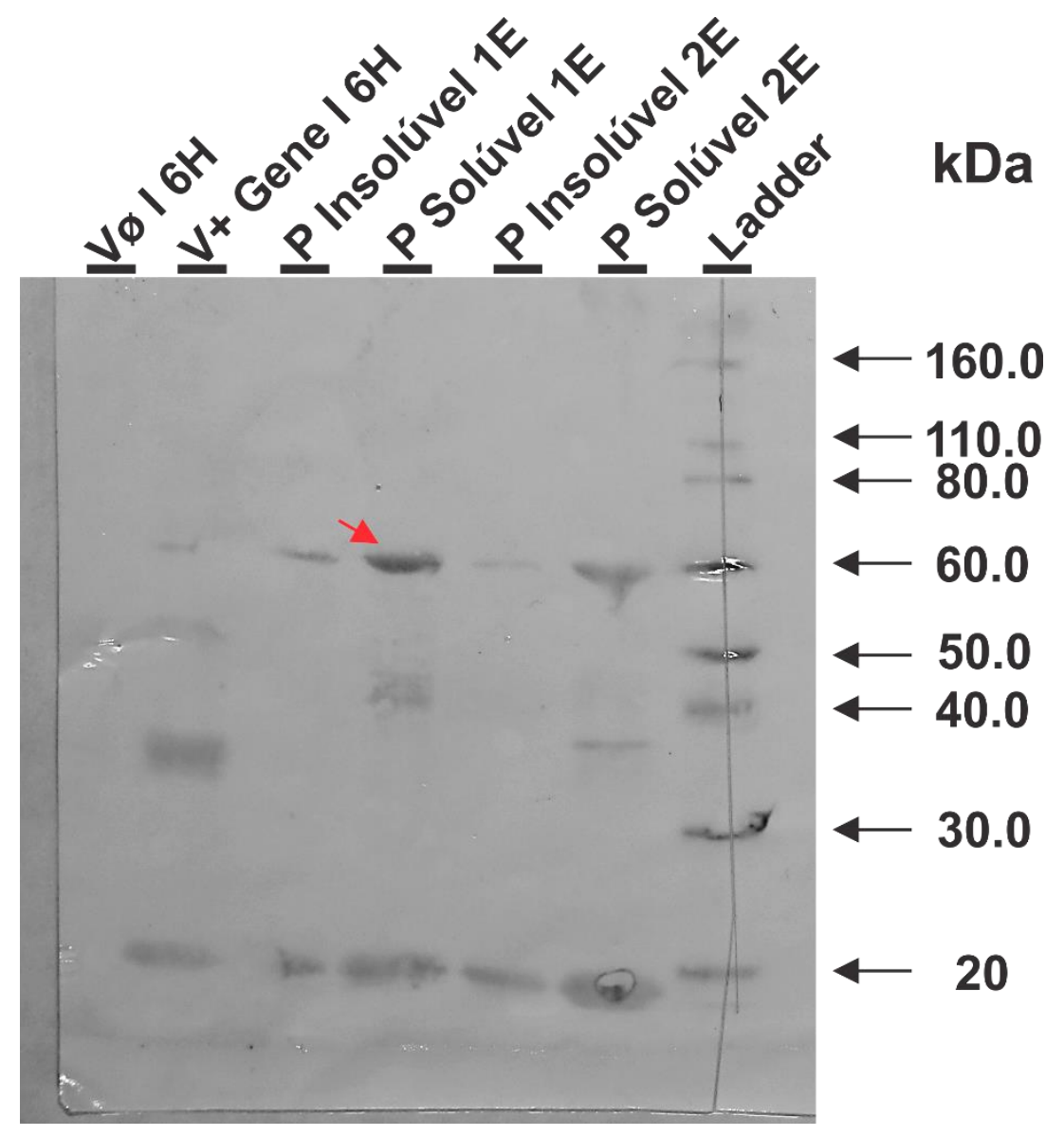

Figura 21: Detecção da rMPP por Western blotting com anticorpo anti calda de histidina da rMPP de sistema procarioto. Western blotting do purificado. Bactéria com vetor fechado e induzida por 6 horas (Vø I 6H); Bactéria com vetor ligado ao gene induzida por 6 horas $(V+G e n e ~ I 6 H)$; Porção insolúvel da Primeira eluição ( $P$ Insolúvel 1E); Porção solúvel da Primeira eluição ( $P$ Solúvel 1E); Porcão insolúvel da Segunda eluição ( $\mathrm{P}$ Insolúvel $2 \mathrm{E})$; Porcão solúvel da Segunda eluição ( $\mathrm{P}$ Insolúvel $2 \mathrm{E}$ ); Marcador de peso molelcular (Ladder) Novex Invitrogen;.

\subsection{Expressão de proteína em modelo eucarioto}

Após 14 dias da eletroporação das culturas de $L$. tarentolae, foram coletados $5 \mathrm{~mL}$ do cultivado e realizada extração de DNA, conforme o item 4.10.3, para análise molecular por PCR da integração do gene de estudo no sistema eucarioto. O resultado da PCR da cultura (Figura 22) sugeriu que o gene estava presente na $L$. tarentolae transfectada quando comparado a cultura de $L$. tarentolae tipo selvagem. A cultura do cinetoplastida com presença do gene integrado foi submetida a sonicação com tratamento de soluções sem/com uréia, item 4.10.4, e realizada purificação de 
proteína, conforme item 4.11, analisado por SDS-PAGE. O resultado seria uma proteína com modificações semelhantes às encontradas em eucariotos (trypanosomatideos) (Dortay e Mueller-Roeber, 2010; Niimi, 2012).

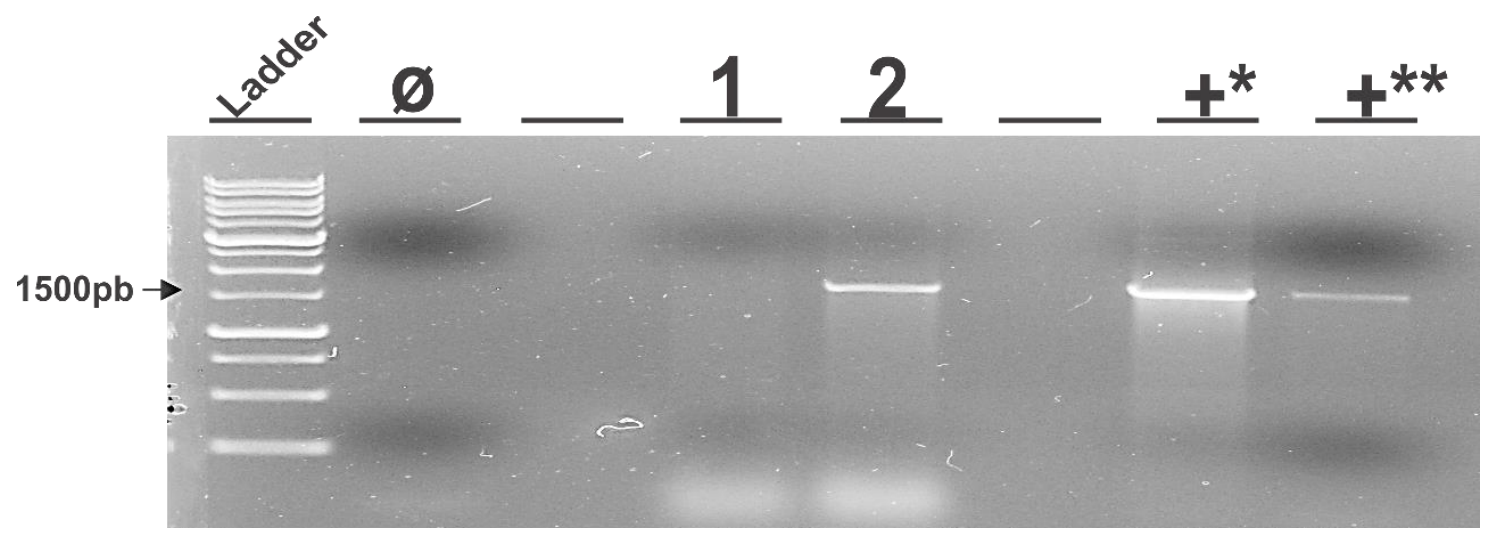

Figura 22: Análise molecular por PCR da presença do gene LDBPK_130760 em L. tarentolae transfectada usando os primers LC10/11. 1 Kb Kasvi (Ladder); Negativo, uso de $2 \mu \mathrm{L}$ de $\mathrm{H}_{2} \mathrm{O}$ tridestilada (ø); L. tarentolae Wild Type (1); L. tarentolae eletroporada (2); Positivo, pGEM ligado ao gene LDBPK_130760 $\left(+^{*}\right)$ e Positvo, DNA genômico de L. chagasi $\left(+^{* *}\right)$.

A análise por SDS-PAGE (Figura 23) indicou que as proteínas estavam eram encontradas no extrato solúvel da Leishamania tarentolae. Este fato era esperado devido as mudanças pós-traducionais que ocorrem em organismos eucariotos e que podem influenciar em sua solubilidade (Niimi, 2012).

\section{Uréia -}

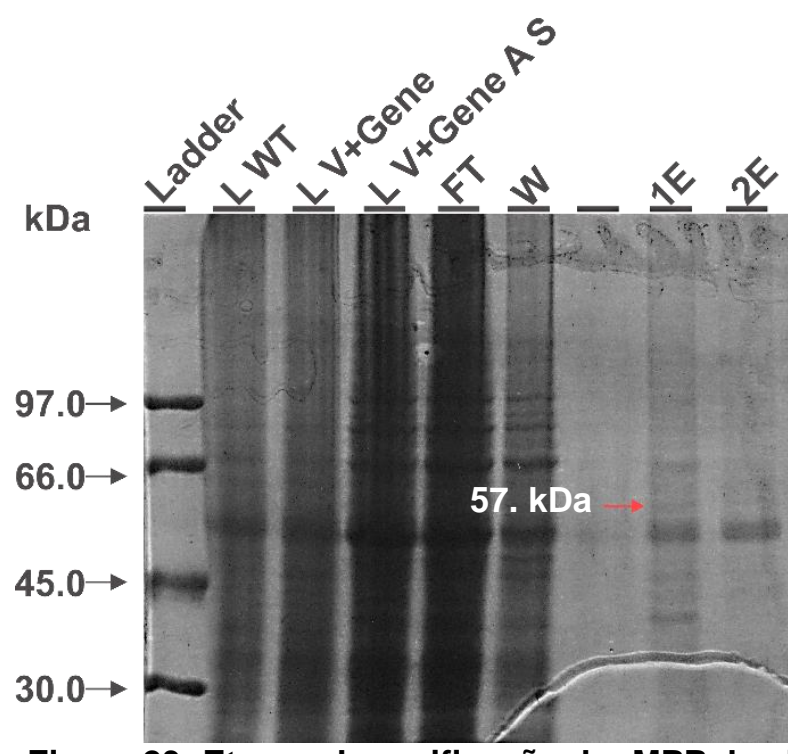

Uréia +

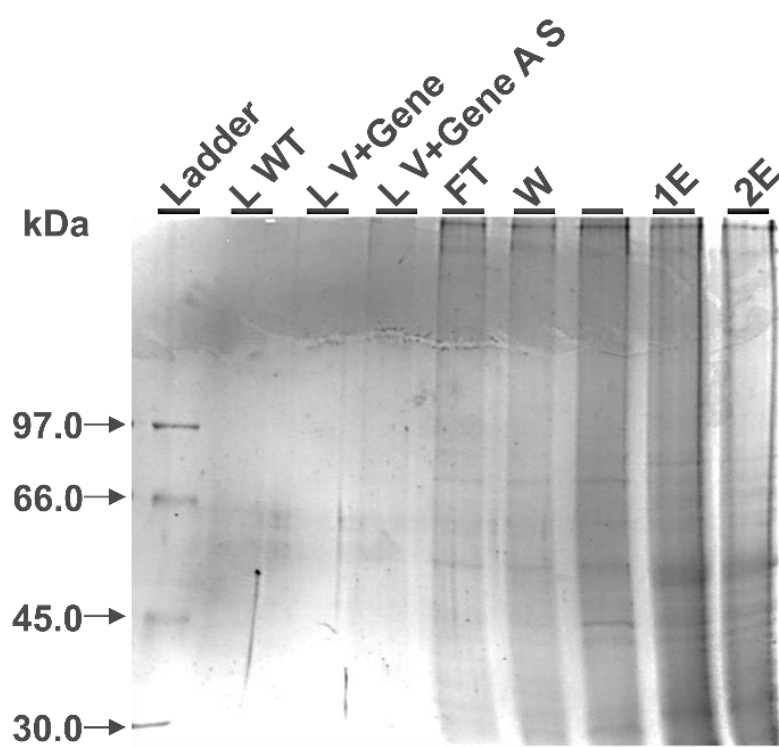

Figura 23: Etapas da purificação da rMPP de sistema eucarioto dos extratos solúvel e insolúvel. Amostras que receberam tratamento sem uréia (Uréia -) e amostras que receberam tratamento com uréia (Uréia +); Ladder Amersham; L. tarentolae wild type (LWT), L. tarentolae transfectada com o gene ( L V+ Gene); L. tarentolae transfectada com o gene antes de sonicar (L V+ Gene A S) Flow trhough (FT), Wash (W); 1E Primeira eluição; 2E Segunda eluição. 
O purificado foi submetido a western blotting com anticorpo anti-His Tag (Figura 24) com intuído de verificar presença da rMPP nas amostras do parasito total transfectado e, como controle, o tipo selvagem. A análise do imunoblotting sugere que a proteína está sendo expressa no modelo eucarioto, contudo, sua expressão é menor acentuada quando comparada ao sistema procarioto. Tal fato pode ser justificado pela diferença dos tempos de replicação entre os organismos. As proteínas de ambos os sistemas foram quantificadas para uso posterior em análise imunológica contra soros de cães por ELISA.

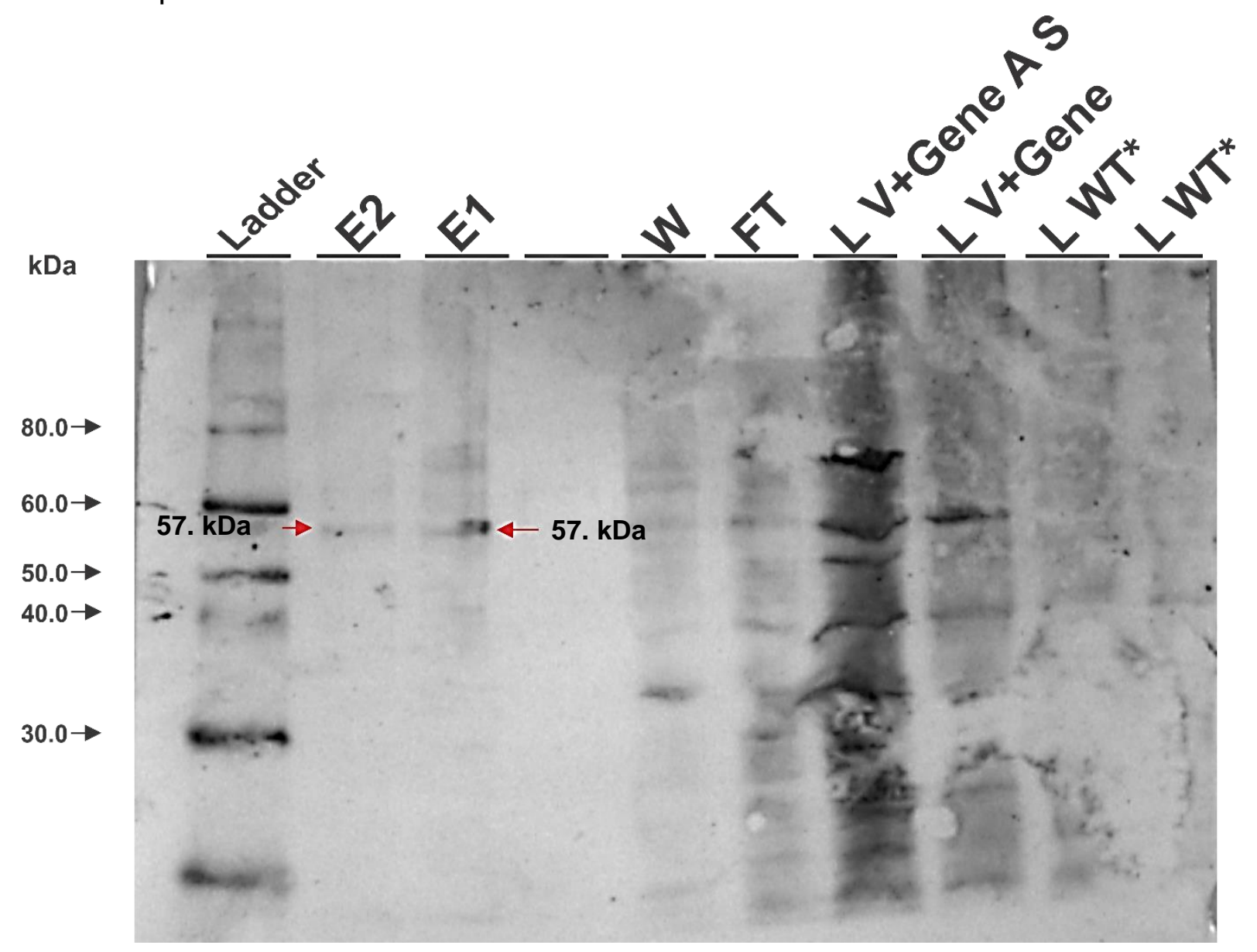

Figura 24: Detecção da rMPP por Western blotting com anticorpo anti calda de histidina da rMPP de sistema eucarioto. $L$. tarentolae wild type $\left(L W T^{\star}\right) ; L$. tarentolae wild type $\left(L W T^{\star \star}\right) ; L$. tarentolae transfectada contendo o gene ( $\mathrm{L} V+\mathrm{Gene}) ; \mathrm{L}$. tarentolae transfectada antes de sonicar ( $\mathrm{L} V+\mathrm{Gene} A$ S); Flow trhough (FT), Wash (W); 1E Primeira eluição; 2E Segunda eluição.

\subsection{Ensaio de Imunoabsorbância Enzimática - ELISA}

Avaliando o potencial da rMPP para diagnóstico de LV, realizamos a análise do preliminar do perfil sorológico usando o método de ELISA, este método foi escolhido para a relização dos ensaios por ser amplamente aplicado em laboratórios 
de rotina devido a sua fácil padronização e execução (Pereira; Sousa e cols, 2013). Depois de escolhido o ensaio sorológico foram realizados o teste sorológico envolvendo 10 amostras de soro de cães, sendo 5 de cães infectados com a forma visceral da doença e 5 de cães sadios, uma vez que os animais infectados produzem anticorpos específicos contra os parasitos do complexo $L$. donovani. Outro fato importante consiste na ausência desta proteína no organismo Canis familiaris, esse dado pode indicar o uso desta metalo-peptidade em possível diagnóstico. Infelizmente náo foi possível realizar a análise sorológica em soros de humanos.

Pelo imunoensaio ELISA, observou-se que, na Figura 25A e 25B, todos os animais infectados apresentavam altas taxas de anticorpos específicos da classe lgG nas diluições de 1:50 e 1:100 com a rMPP, contudo, está proteína do sistema eucarioto (Figura 25B) também influenciavam animais não infectados a apresentarem níveis altos de $\lg G$, fato não ocorrido no sistema procarioto. Somente nos ensaios envolvendo a proteína heteróloga do sistema procarioto de 1:50 e 1:100 (Figura 25A) houve resultados que estão de acordo com os obtidos pelo Laboratório de Leishmanioses, departamento de parasitologia - UFMG, que confirmaram a positividade dos cães para leishmaniose visceral. A análise do ensaio na diluição de 1:1000 na Figura 25B revelou que esta tinha maior sensibilidade que as demais diluições no ensaio do mesmo sistema, onde $80 \%$ dos animais infectados apresentaram reatividade contra a proteína heteróloga.

Ao comparar as Figuras 25A e 25B, nota-se diferenças das taxas de IgG contra as proteínas heterólogas de ambos sistemas, esse fato pode estar relacionado a qualidade da purificaçáo da rMPP, a qual acreditamos ter interferido nos resultados de ELISA da rMPP de sistema eucarioto .Contudo, se não houvesse tal interferente, as comparações dos resultados obtidos mostrariam que os ensaio em sistema procarioto tiveram maior desempenho que o sistema eucarioto, porém, somente na diluição 1:1000 que houve animais negativos acima do ponto de corte estimado, fato não ocorrido no sistema eucarioto. 
A

Proteína Heteróloga - Sistema Procarioto

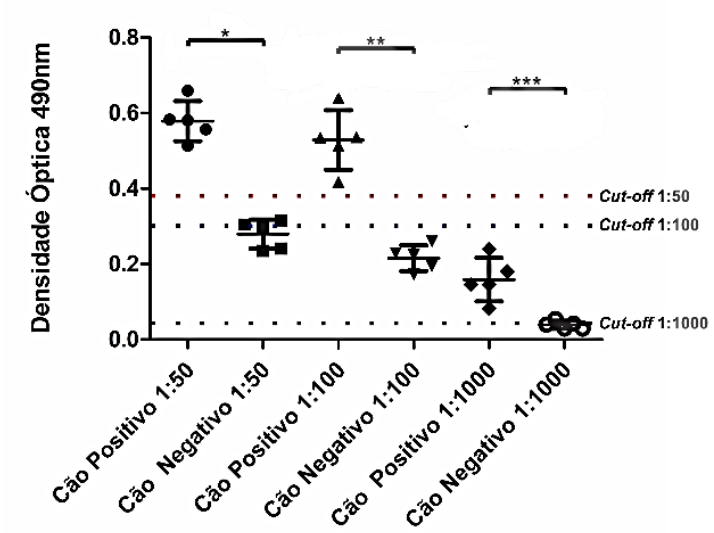

Proteína Heteróloga - Sistema Eucarioto

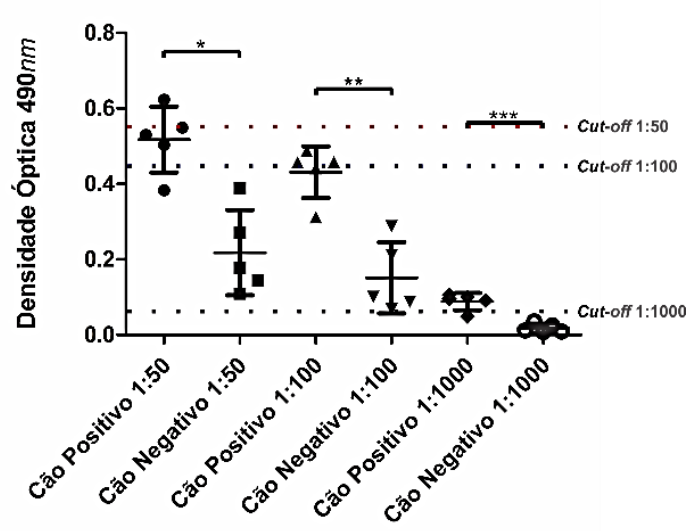

Figura 25: Avaliação de antigenicidade da proteína XP_001464106.1 dos sistemas procarioto e eucarioto por ELISA. A Avaliação da proteína heteróloga obtida de sistema procarioto em diferentes diluições de soro. ${ }^{*} p$ value $<0.001 ;{ }^{* *} p$ value $<0.001$; ${ }^{* * *} p$ value $<0.01$. B Avaliação da proteína heteróloga obtida de sistema eucarioto em diferentes diluições de soro. ${ }^{*} p$ value $<0.01 ;{ }^{* *} p$ value $<0.01 ; \mathrm{e}^{* * \star} p$ value $<0.01$

Os dados do teste de ELISA das Figuras 25A e 25B foram submetidos a análise estatística de colunas. Os resultados obtidos pelo uso do teste t aplicados a todos os ensaios foram $p$ value $<0.01$, mostrando significância estatística (du Prel e cols, 2009) e dando credibilidade na hipótese de uso desta proteína em possível diagnóstico para LV.

Diversos autores adotaram estratégias similares para idenfiticar um possível candidato a marcador de diagnóstico (Carvalo e cols, 2011; Bottino e cols, 2013; Menezes-Sousa e cols, 2014; Duthie e cols, 2016). A grande maioria dos autores fez uso de proteínas recombinantes para imunoensaios e mostraram uma maior sensibilidade e especifidade comparadas aos ensaios com uso extratos totais de proteínas solúveis de Leishmania (Soto e cols, 1998; Maia e cols, 2012). Contudo, a escolha do candidato a marcador para diagnóstico com maior sensibilidade e espeficidade dependerá do grau de exclusividade (espécie ou gênero-especifico), isso acarretará redução em reações cruzadas entre espécies de organismos parasitários (Peacock e cols, 2007; Sousa e cols, 2013). Nosso resultado preliminar mostrou que a rMPP pode discriminar cães infectados de cães sadios e que possui $p$ value $<0.01$ que valida a hipótese de uso deste antígeno como marcador de diagnóstico, contudo, 
nos testes realizados por outros autores há necessidade de aumentar nosso número de amostra (n) para poder verificar se a rMPP pode realmente manter essa discriminação de infectados e não infectados (Bottino e cols, 2013; Menezes-Sousa e cols, 2014; Gao e cols, 2015; Agallou e cols, 2016). Além disso, o aumento de n amostral poderá contribuir nos dados de reatividade de soros infectados com outras espécies de tripanossomatídeos e, assim, poderá ser determinado sua sensibilidade, especificidade, valores preditivos negativos e positivos. Se a rMPP tiver reatividade com outros organismos poderá ser, então, selecionada as áreas de maior antigenicidade que apareçam nos parasitos do complexo donovani e combina-las em proteínas quimeras aumentando, assim, sua especificidade e sensibilidade como visto, por exemplo, por Soto e cols (1998) e Rosati e cols (2001). Além disso, combinações entre a proteína recombinante com outros marcadores já usados comercialmente (rK26 e rK39) poderiam aumentar sua sensibilidade e espeficidade, além de eliminar reações cruzadas (Gao e cols, 2015; Vallur e cols, 2016) entre organismos similares ( $T$. cruzi), que podem ocorrer em humanos, ou microorganismos que ocorrem em canídeos, como Ehrlichia canis e Babesia (Krawczak e cols, 2015).

Por essas razões, o novo candidado a marcador de diagnóstico desenvolvido pelo presente trabalho tem potencial para ser tornar um marcador de diagnóstico para LV, contudo, necessita de novos testes para determinar sua sensibilidade, especificidade e possíveis reações cruzadas, assim como ocorrido com outras diversas proteínas recombinantes, entre elas k39, KMPII, Peroxidoxinas, LACK, histonas nucleossomais ( $\mathrm{H} 2 \mathrm{~A}, \mathrm{H} 2 \mathrm{~B}, \mathrm{H} 3$ e H4) e proteínas de choque térmico (HSP60, 70 e 83) (Menezes e cols 2015). 


\section{CONSIDERAÇÕES FINAIS}

O presente trabalho avaliou a proteína metalopeptidase, clã ME, família M16 para diagnóstico de LV, os dados do imunoensaio (ELISA) mostraram significância estatística, porém, faz-se necessário aumentar a amostra e realizar novos testes para determinar sua sensibilidade, especificidade, valor preditivo positivo e valor preditivo negativo. Além disso, há necessidade de verificar a ocorrência de reações cruzadas contra parasitos que causem a leishmaniose tegumentar, devido ao fato de que o gene que codifica tal proteína estar presente em genomas de outras espécies de Leshmania.

Há necessidade de verificar possíveis combinações entre a proteína recombinante com marcadores já encontrados comercialmente, analisando se há alterações em sua sensibilidade e especificade.

Contudo, o gene que traduz essa proteína não é totalmente presente no genoma de espécies de T.cruzi, isso pode indicar uma atenuação das reações cruzadas entre esses trypanosomatideos. Outras proteínas, também, foram citadas como gênero-especificas na literatura e, com isso, se faz necessário o estudo de sua expressão entre espécies diferentes de Leishmania e a sua aplicação como marcadores em diagnóstico.

A obtenção da MPP recombinante possibilitará também o avanço em estudos que objetivem sua caracterização funcional e bioquímica, como determinação de localização intracelular e secreção (com uso de anticorpos específicos), tanto na forma promastigota quanto amastigota. A futura cristalização e resolução da estrutura tridimensional da MPP possibilitará o estudo e desenho de inibidores para ensaios de cinética enzimática e de inibição in vitro e in vivo. 


\section{BIBLIOGRAFIA}

ABBAS A K.; LICHTMAN A. H.; PILLAI S. Imunologia Celular e Molecular. Saunders Elsivier. São Paulo. $7^{\circ}$ edição, 545 paginas, 2011.

ADLER S, BER M. Transmission of Leishmaniatropica by the bite of Phlebotomus papatasi. Ind J Med Tes 29:803. 1941. Disponível em: < http://www.cabdirect.org/abstracts/19421000279.html;jsessionid=02F063C122471 AB 14ED024769620BABF>

AGALLOU M.; ATHANASIOU E.; SAMIOTAKI M.; PANAYOTOU G.; KARAGOUNI E. Identification of Immunoreactive Leishmania infantum Protein Antigens to Asymptomatic Dog Sera through Combined Immunoproteomics and Bioinformatics Analysis. PLoS ONE 11(2): e0149894. 2016. Disponível em: $<$ doi:10.1371/journal.pone.0149894>

AKHOUNDI M.; KUHLS K.; CANNET A.; VOTÝPKA J.; MARTY P.; DELAUNAY P. e cols. A Historical Overview of the Classification, Evolution, and Dispersion of Leishmania Parasites and Sandflies. PLoS Negl Trop Dis 10(3): e0004349. Disponível em: <doi: 10.1371/journal.pntd.0004349>

ALMEIDA A. B.P.F.; SOUSA V. R. F.; GASPARETTO N. D.; SILVA G. F.R.; FIGUEIREDO F. B.; DUTRA V.; NAKAZATO L.; MADEIRA M. F. Canine visceral leishmaniasis: diagnostic approaches based on polymerase chain reaction employing different biological samples. Diagnostic Microbiology and Infectious Disease 76, 321-324. 2013. Disponível em <doi.org/10.1016/j.diagmicrobio.2013.03.017>

ALRAJHI A. A. Cutaneous leishmaniasis of the Old World. Skin Therapy Lett. Feb; 8(2) :1-4. 2003. Disponível em: <PMID:12728282 >

ALTAMIRANO-ENCISO, A. J.; MARZOCHI, M.C. A.; MOREIRA, J. S.; SCHUBACH, A. O. e MARZOCHI, K. B. F.: On the origin and spread of cutaneous and mucosal leishmaniasis, based on pre- and post-Colombian historical sources? Hist Cienc Saude Manguinhos, Sep-Dec;10(3):852-82. 2003. Disponível em: <PMID: 14994709>

ALVAR J, VE'LEZ ID, BERN C, HERRERO M, DESJEUX P. Leishmaniasis worldwide and global estimates of its incidence. PLoS One; 7(5):e35671. Disponível em: <doi: 10.1371/journal.pone.0035671>

ASHFORD R.W. The leishmaniases as emerging and reemerging zoonoses. International Journal for Parasitology 30,1269-1281. 2000. Disponível em: < PMID: $11113254>$

BAÑULS A. L.; HIDE M.; PRUGNOLLE F. Leishmania and the leishmaniases: a parasite genetic update and advances in taxonomy, epidemiology and pathogenicity in humans. Adv Parasitol, 64:1-109. 2007. Disponível em: <PMID: 17499100> 
BASHIRUDDIN J. B. Extraction of DNA from Mycoplasmas. Mycoplasma Protocols: a Laboratory Manual. New Jersey, Humana Press Inc.1998 Chap 17; p141-144. Disponível em:<10.1385/0-89603-525-5:141>

BHARGAVA P.; SINGH R. Developments in Diagnosis and Antileishmanial Drugs. Interdisciplinary Perspectives on Infectious Diseases, 2012:626838. 2012. Disponível em: <doi:10.1155/2012/626838>

BIFELD E.; CLOS J. The genetics of Leishmania virulence. Med Microbiol Immunol, Dec; 204(6):619-34. 2015. Disponível em: <doi: 10.1007/s00430-015-0422-1>

BLOM N.; GAMMELTOFT S.; BRUNAK, S. Sequence- and structure-based prediction of eukaryotic protein phosphorylation sites. Journal of Molecular Biology: 294(5): 1351-1362, 1999. Disponível em: <PMID: 10600390>

BLOM N.; SICHERITZ-PONTÉN T.; GUPTA R.; GAMMELTOFT S.; BRUNAK S. Prediction Of Post-Translational Glycosylation And Phosphorylation Of Proteins From The Amino Acid Sequence. Proteomics, jun;4(6):1633-49. 2004. Disponível em: <PMID: 15174133>

BOARINO A.; BOLLO E.; PRUNOTTO L.; CANALE L.; USLENGHI F.; POLETTI P. Application of a recombinant protein for the serological diagnosis of canine leishmaniasis. Comp Immunol Microbiol Infect Di, Nov;31(6):527-36. 2008. Disponível em: <doi: 10.1016/j.cimid.2007.09.002>

BORNHORST J. A.; FALKE J. J. Purification of Proteins Using Polyhistidine Affinity Tags. Methods Enzymo, 326: 245-254. 2000. Disponível em: <PMC2909483>

BOTTINO C. G.; GOMES L. P. PEREIRA J. B. e cols. Chagas disease-specific antigens: characterization of epitopes in CRA/FRA by synthetic peptide mapping and evaluation by ELISA-peptide assay. BMC Infect Dis. 13: 568. 2013. Disponivel em: $<$ doi: 10.1186/1471-2334-13-568>

CARVALHO G. B; SILVA-PEREIRA R. A; PACÍFICO L. G; FONSECA C. T. Identification of Schistosoma mansoni candidate antigens for diagnosis of schistosomiasis. Mem Inst Oswaldo Cruz. Nov;106(7):837-43. 2011. Disponivel em: <PMID: 22124556>

CENTERS FOR DISEASE CONTROL AND PREVENTION (CDC). Acessado em 15 de janeiro de 2016.2 Disponível em: <http://www.cdc.gov/parasites/leishmaniasis/health_professionals/>

CHAPPUIS F.; SUNDAR S.; HAILU A.; GHALIB H.; RIJAL S.; PEELING W. R.; ALVAR J.; BOELAERT M. Visceral leishmaniasis: what are the needs for diagnosis, treatment and control? Nature Reviews Microbiology , S7-S16 . 2007. Disponível em: <doi:10.1038/nrmicro1748>

CHAUHAN J. S.; RAO A.; RAGHAVA G. P. In silico platform for prediction of N-, Oand C-glycosites in eukaryotic protein sequences. PLoS One; Jun 28;8(6): e67008. 2013. Disponivel em:<doi: 10.1371/journal.pone.0067008. Print 2013> 
CLEM A. A Current Perspective on Leishmaniasis. J Glob Infect Dis. May-Aug; 2(2): 124-126. 2010. Disponível em: <doi: 10.4103/0974-777X.62863>

DAS L.; DATTA N.; BANDYOPADHYAY S.; DAS K. P. Successful Therapy of Lethal22 Murine Visceral Leishmaniasis with Cystatin Involves Up-Regulation of Nitric Oxide and Favorable T Cell Response. J Immunol, 166:4020-4028. 2000. Disponível em: <doi: 10.4049/jimmunol.166.6.4020>

DAVIDSON N. R. Leishmaniasis. Protozoal Tropical Infections, 33, Issue 8, Pages 43-46. 2005. Disponível em: <doi:10.1016/S1357-3039(07)70001-4>

DAWIT G.; GIRMA Z.; SIMENEW K. A Review on Biology, Epidemiology and Public Health Significance of Leishmaniasis. J Bacteriol Parasitol 4:166. 2012. Disponível em: < doi:10.4172/2155-9597.1000166>

DAYAKAR A.; CHANDRASEKARAN S.; VERONICA J.; MAURYA R. Role of leptin in human visceral leishmaniasis? Medical Hypotheses, 77, 416-418. 2011. Disponível em: < doi: 10.1016/j.mehy.2011.05.032>

de MORAIS G. C. V.; LIMA A. K. C.; TERRA R.; SANTOS R. F.; SILVA S. A. G.; DUTRA P. M. L. The Dialogue of the Host-Parasite Relationship:Leishmania spp. and Trypanosoma cruzi Infection. BioMed Research International, volume, Article ID 324915, 19 pages. 2015. Disponivel em: < doi: 10.1155/2015/324915>

de Ruiter C. M.; van der Veer C.; Leeflang M. M.; Deborggraeve S.; Lucas C.; Adams E. R. Molecular tools for diagnosis of visceral leishmaniasis: systematic review and meta-analysis of diagnostic test accuracy. J Clin Microbiol., Sep;52(9):3147-55. 2014. Disponível em:<doi: 10.1128/JCM.00372-14>

DESJEUX P. Leishmaniasis: current situation and new perspectives. Comp Immunol Microbiol Infect Dis, Sep;27(5):305-18. 2004. Disonivel em: <PMID: 15225981>

DESY S.; SCHNEIDER A.; MANI J. Trypanosoma brucei has a canonical mitochondrial processing peptidase. Mol Biochem Parasitol. 2012 Oct;185(2):161-4. 2012. Disponível em: <doi: 10.1016/j.molbiopara.2012.07.005>

DORTAY H.; MUELLER-ROEBER B. Research A highly efficient pipeline for protein expression in Leishmania tarentolae using infrared fluorescence protein as marker. Microb Cell Fact, May 10;9:29. 2010. Disponível em: <doi: 10.1186/1475-2859-9-29>

DUTHIE S.M; RAMAN S.V; PIAZZA M. F; REED G.S. The Development and Clinical Evaluation of Second-Generation Leishmaniasis Vaccines. Vaccine, January 5; 30(2): 134-141. 2012. Disponível em: <doi: 10.1016/j.vaccine.2011.11.005>

DUTHIE M. S.; FAVILA M.; HOFMEYER K. A.; e cols. Strategic evaluation of vaccine candidate antigens for the prevention of Visceral Leishmaniasis. Vaccine. May 27;34(25):2779-86. 2016. Disponivel em: <doi: 10.1016/j.vaccine.2016.04.067> 
du PREL J-B.; HOMMEL G.; ROHRIG B.; BLETTNER M. Confidence Interval or PValue? Dtsch Arztebl Int. May; 106(19): 335-339. 2009. Disponivel em: <doi: 10.3238/arztebl.2009.0335>

DVORÁK J.; MASHIYAMA S. T.; BRASCHI S.; SAJID M.; KNUDSEN G. M.; HANSELL E.; LIM K. C.; HSIEH I.; BAHGAT M.; MACKENZIE B.; MEDZIHRADSZKY K. F.; BABBITT P. C.; CAFFREY C. R.; MCKERROW J. H. Differential use of protease families for invasion by schistosome cercariae. Biochimie, Feb;90(2):345-58. 2008. Disponível em: <PMID: 17936488>

EBRAHIM G. J. Leishmaniasis. Jornal of tropical pediatrics, Vol 46, page 128-130. 2000. Disponível em: < PMID:10893911>

ESCOLL P.; MONDINO S.; ROLANDO M.; BUCHRIESER C. Targeting of host organelles by pathogenic bacteria: a sophisticated subversion strategy. Nat Rev Microbiol. Jan;14(1):5-19. 2016. Disponível em: <doi: 10.1038/nrmicro.2015>

FERREIRA, M. U. Parasitologia contemporânea. Rio de Janeiro, Guanabara Koogan, 2012. 439 páginas.

FSADNI C.: FSADNI P.; PISCOPO T.; AZZOPARDI C. M. Laryngeal leishmaniasis in Malta. J Infect, Feb;54(2): e61-3. 2006. Disponível em: <PMID: 16797076>

GAO X. B.; XIAO M.; WANG J.; LIU Y. J.; LIU Q. Z.; QI M. L. Optimization of candidate proteins for serological screening of Chlamydia trachomatis infection. Genet. Mol. Res. 14 (4): 12240-12246. 2015. Disponível em: <DOI http://dx.doi.org/10.4238/2015.October.9.12>

GEIGER A.; HIRTZ C.; BÉCUE T.; BELLARD E.; CENTENO D.; GARGANI D.; ROSSIGNOL M.; CUNY G.; PELTIER J. B. Exocytosis and protein secretion in Trypanosoma. BMC Microbiology, 10:20. 2010. Disponível em: <doi: 10.1186/14712180-10-20>

GRIBBEN J. G.; DEVEREUX S.; THOMAS N. S.; e cols. Development of antibodies to unprotected glycosylation sites on recombinant human GM-CSF. Lancet. Feb 24;335(8687):434-7. 1990. Disponivem em: <PMID: 1968169>

GOSSAGE S. M.; ROGERS M. E.; BATES P. A. Two separate growth phases during the development of Leishmania in sand flies: implications for understanding the life cycle. Int J Parasitol, Sep 15;33(10):1027-34. 2003. Disponível em: <PMID: $13129524>$

GOTO H.; LINDOSO J. A. L. Current diagnosis and treatment of cutanous and monocutaneous leishmaniasis. Expert Review of Anti-Infective Therapy, vol 8, n.04 pp. -419-43, 2010. Disponível em: < doi:10.1586/eri.10.19> 
GRÄSLUND S.; NORDLUND P.; WEIGELT J.; e cols. Protein production and purification. Nat Methods, February; 5(2): 135-146. 2008. Disponível em: <doi:10.1038/nmeth.f.202>

GRIMALDI G. JR.; TESH R. B. Leishmaniases of the New World: current concepts and implications for future research. Clin Microbiol Rev, Jul;6(3):230-50. 1993. Disponivel em: <PMID: 8358705>

GUPTA R.; BRUNAK, S. Prediction of glycosylation across the human proteome and the correlation to protein function. Pacific Symposiumon Biocomputing, v. 7, p. 310322, 2002. Disponível em: < PMID: 11928486 >

GUPTA K. R. Immunology and Medical Microbiology. 2007. Disponível online:< http://nsdl.niscair.res.in/jspui/bitstream/123456789/454/1/Antigens.pdf>

HASHIGUCHI Y.; GOMEZ E. L.; KATO H.; MARTINI L. R.; VELEZ L. N.; UEZATO H. Diffuse and disseminated cutaneous leishmaniasis: clinical cases experienced in Ecuador and a brief review. Trop Med Health. 44: 2. 2016. Disponível em: <doi: 10.1186/s41182-016-0002-0>

HERENIO E. M.; FORTES R. C.; RINCON G. Prevalência da Leishmaniose visceral em cães do Distrito Federal, segundo dados do centro de zoonoses de Brasília. $\boldsymbol{J}$ Health Sci Inst. ;32(2):126-9. 2014. Disponível em: < http://www.unip.br/comunicacao/publicacoes/ics/edicoes/2014/02_abrjun/V32_n2_2014_p126a129.pdf>

HIDE M; BUCHETON B; KAMHAWI S; BRAS-GONÇALVES R; SUNDAR S; LEMESRE J.-L; BANULS A.-L. Understanding Human Leishmaniasis: The Need for an Integrated Approach. Encyclopedia of Infectious Diseases: Modern Methodologies, 2007. 747 páginas.

JISHA V. N; SMITHA R. B.; PRADEEP S.; E COLS. Versatility of microbial proteases. Advances in Enzyme Research, Vol.1, No.3, 39-51. 2013. Disponivel em: <http://dx.doi.org/10.4236/aer.2013.13005>

JOHNSON L. N. The regulation of protein phosphorylation. Biochem Soc Trans, Aug;37(Pt 4):627-41. 2009. Disponível em: <doi: 10.1042/BST0370627>

IVENS A. C.; PEACOCK C. S.; WORTHEY E. A.; MURPHY L.; AGGARWAL G.; BERRIMAN M.; SISK E.; RAJANDREAM MA, ADLEM E, AERT R, ANUPAMA A, APOSTOLOU Z, ATTIPOE P, BASON N, BAUSER C, BECK A, BEVERLEY SM, BIANCHETTIN G, BORZYM K, BOTHE G, BRUSCHI CV, COLLINS M, CADAG E, CIARLONI L, CLAYTON C, COULSON RM, CRONIN A, CRUZ AK, DAVIES RM, DE GAUDENZI J, DOBSON DE, DUESTERHOEFT A, FAZELINA G, FOSKER N, FRASCH AC, FRASER A, FUCHS M, GABEL C, GOBLE A, GOFFEAU A, HARRIS D, HERTZ-FOWLER C, HILBERT H, HORN D, HUANG Y, KLAGES S, KNIGHTS A, KUBE M, LARKE N, LITVIN L, LORD A, LOUIE T, MARRA M, MASUY D, MATTHEWS K, MICHAELI S, MOTTRAM JC, MÜLLER-AUER S, MUNDEN H, NELSON S, NORBERTCZAK H, OLIVER K, O'NEIL S, PENTONY M, POHL TM, PRICE C, PURNELLE B, QUAIL MA, RABBINOWITSCH E, REINHARDT R, RIEGER M, RINTA 
J, ROBBEN J, ROBERTSON L, RUIZ JC, RUTTER S, SAUNDERS D, SCHÄFER M, SCHEIN J, SCHWARTZ DC, SEEGER K, SEYLER A, SHARP S, SHIN H, SIVAM D, SQUARES R, SQUARES S, TOSATO V, VOGT C, VOLCKAERT G, WAMBUTT R, WARREN T, WEDLER H, WOODWARD J, ZHOU S, ZIMMERMANN W, SMITH DF, BLACKWELL JM, STUART KD, BARRELL B, MYLER PJ. The Genome of the Kinetoplastid Parasite, Leishmania major. Science, Jul 15;309(5733):436-42. 2005. Disponível em: <PMID: 16020728>

KRAWCZAK FDA. S.; REIS I. A.; SILVEIRA J. A; AVELAR D. M.; MARCELINO A. P.; WERNECK G. L.; LABRUNA M. B.; PAZ G. F. Leishmania, Babesia and Ehrlichia in urban pet dogs: co-infection or cross-reaction in serological methods? Rev Soc Bras Med Trop. Jan-Feb;48(1):64-8. 2015. Disponível em: <doi: 10.1590/0037-8682-02912014>

LAINSON R.; SHAW J. J.; SILVEIRA F. T.; BRAGA R. R. American visceral leishmaniasis: on the origin of Leishmania (Leishmania) chagasi. Trans R Soc Trop Med Hyg, 81(3):517. 1987. Disponível em: <PMID: 3686647 http://www.ncbi.nlm.nih.gov/pubmed/3686647>

LAINSON, R. The Neotropical Leishmania species: a brief historical review of their discovery, ecology and taxonomy. Revista Pan-Amazônica de Saúde, 1 (2). 2010. Disponível em: <http://doi.org/10.5123/S2176-62232010000200002>

LAMBERTZ U.; SILVERMAN J. M.; NANDAN D.; MCMASTER W. R.; CLOS J.; FOSTER L. J.; REINER N. E. Secreted virulence factors and immune evasion in visceral leishmaniasis. J Leukoc Biol, Jun;91(6):887-99. 2012. Disponível em:<doi: 10.1189/jlb.0611326>

LARSEN J. E. P.; LUND O. D.; NILSEN M. Improved method for predicting linear Bcell epitopes. Immunome Res.; 2: 2. 2006. Disponível em: < PMID: 16635264>

LEE J. J. Illustrated Guide To The Protozoa. Publicado por Allen Press, Volume 1. 689 paginas.

LEISHMAN, W. B.; M. B.; R. AM. C. On the possibility of the occurrence of Trypanosomiasis in India. The British Medical Journal, 1 (2213), 1252-1254. 1903. Disponível em: <http://PMC2513550>

MADALOSSO G.; FORTALEZA M. C.; RIBEIRO F. A.; RIBEIRO F. A.; CRUZ L. L; NOGUEIRA A. P.; LINDOSO A. L. J. American Visceral Leishmaniasis: Factors Associated with Lethality in the State of Sao Paulo, Brazil. Journal of Tropical Medicine Volume 2012, Article ID 281572, 7 page. 2012. Disponível em: $<$ doi:10.1155/2012/281572>

MAIA Z.; LÍRIO M.; MISTRO S.; MENDES C. M.; MEHTA S. .; BADARO R. Comparative study of rK39 Leishmania antigen for serodiagnosis of visceral leishmaniasis: systematic review with meta-analysis. PLoS Negl Trop Dis. Jan;6(1):e1484. 2012. Disponível em: <doi: 10.1371/journal.pntd.0001484> 
MAHMOOD T.; YANG P. C. Western blot: technique, theory, and trouble shooting. N Am J Med Sci. Sep;4(9):429-34. 2012. Disponivel em: <doi: 10.4103/19472714.100998>

MENDES T. A. O.; CUNHA J. L. R.; LOURDES R. A.; e cols. Identification of StrainSpecific B-cell Epitopes in Trypanosoma cruzi Using Genome-Scale Epitope Prediction and High-Throughput Immunoscreening with Peptide Arrays. PLoS Negl Trop Dis. Oct; 7(10): e2524. 2013. Disponível em: <doi: 10.1371/journal.pntd.0002524>

MENEZES-SOUZA D; MENDES T. A. O; NAGEM R. A. P. e cols. Mapping B-Cell Epitopes for the Peroxidoxin of Leishmania (Viannia) braziliensis and Its Potential for the Clinical Diagnosis of Tegumentary and Visceral Leishmaniasis. PLoS One. ; 9(6): e99216. 2014. Disponivel em: <doi: 10.1371/journal.pone.0099216>

MENEZES-SOUZA D; MENDES T. A. O; GOMES MDS, BARTHOLOMEU D. C; FUJIWARA R. T. Improving Serodiagnosis of Human and Canine Leishmaniasis with Recombinant Leishmania braziliensis Cathepsin L-like Protein and a Synthetic Peptide Containing Its Linear B-cell Epitope. PLoS Negl Trop Dis 9(1): e3426. 2015. Disponível em:<doi:10.1371/journal.pntd.0003426>

MINISTÉRIO DA SAÚDE (MDS). Secretaria de Vigilância em Saúde. Departamento de Vigilância Epidemiológica. Manual de Vigilância e Controle da Leishmaniose Visceral. Secretaria de Vigilância em Saúde. Departamento de Vigilância Epidemiológica. Brasília: Ministério da Saúde, 2006. Disponível em: < http://bvsms.saude.gov.br/bvs/publicacoes/manual_vigilancia_controle_leishmaniose -visceral.pdf>

MINISTÉRIO DA SAÚDE (MDS). Secretaria de Vigilância em Saúde. Departamento de Vigilância Epidemiológica. Manual de Vigilância e Controle da Leishmaniose Tegumentar Americana. Secretaria de Vigilância em Saúde. Departamento de Vigilância Epidemiológica. Brasília: Ministério da Saúde, 2007. Disponível em: $<$ http://bvsms.saude.gov.br/bvs/publicacoes/manual_vigilancia_leishmaniose_2ed.pd f>

MINISTÉRIO DA SAÚDE (MDS). Secretaria de Vigilância em Saúde. Departamento de Vigilância Epidemiológica. Manual de Vigilância e Controle da Leishmaniose Visceral. Secretaria de Vigilância em Saúde. Departamento de Vigilância Epidemiológica. Brasília: Ministério da Saúde, 2014. Disponível em: $<$ http://bvsms.saude.gov.br/bvs/publicacoes/manual_vigilancia_controle_leishmanios e_visceral_1edicao.pdf>

MINISTÉRIO DA SAÚDE (MDS). Situação Epidemiológica - Dados. Acessado dia 5 de junho de 2016a. Disponível em: < http://portalsaude.saude.gov.br/images/pdf/2016/fevereiro/24/LTA-Casos-14.pdf>

MINISTÉRIO DA SAÚDE (MDS). Situação Epidemiológica - Dados. Acessado dia 5 de junho de 2016b. Disponível em: <http://portalsaude.saude.gov.br/images/pdf/2016/maio/20/LV-Casos.pdf > 
MOTTA M. C.; MARTINS A. C.; DE SOUZA S. S.; CATTA-PRETA C. M.; SILVA R.; KLEIN C. C.; DE ALMEIDA L. G.; DE LIMA CUNHA O.; CIAPINA L. P.; BROCCHI M.; COLABARDINI A. C.; DE ARAUJO LIMA B.; MACHADO C. R.;; DE ALMEIDA SOARES C. M.; PROBST C. M.; DE MENEZES C. B.; THOMPSON C. E.; BARTHOLOMEU D. C.; GRADIA D. F.; PAVONI D. P.; GRISARD E. C.; FANTINATTIGARBOGGINI F.; MARCHINI F. K.; RODRIGUES-LUIZ G. F.; WAGNER G.; GOLDMAN G. H.; FIETTO J. L.; ELIAS M. C.; GOLDMAN M. H.; SAGOT M. F.; PEREIRA M.; STOCO P. H.; DE MENDONCCA-NETO R. P.; TEIXEIRA S. M.; MACIEL T. E.; DE OLIVEIRA MENDES T. A.; ÜRMENYI T. P.; DE SOUZA W.; SCHENKMAN S.; DE VASCONCELOS A. T. Predicting the proteins of Angomonas deanei, Strigomonas culicis and their respective endosymbionts reveals new aspects of the trypanosomatidae family. PLoS One ;8(4): e60209. 2013. Disponível em: <doi: 10.1371/journal.pone.0060209>

NEUBER H. Leishmaniasis. JDDG; 9:754-765. 2008. Disponível em: doi:<10.1111/j.1610-0387.2008.06809>

NIIMI T. Recombinant protein production in the eukaryotic protozoan parasite Leishmania tarentolae: a review. Methods Mol Biol; 824:307-15. 2012. Disponível em: <doi: 10.1007/978-1-61779-433-9_15>

PEACOCK C. S.; SEEGER K.; HARRIS D.; MURPHY L. e cols. Comparative genomic analysis of three Leishmania species that cause diverse human disease. Nat Genet. Jul;39(7):839-47. 2007. Disponível em: <doi: 10.1038/ng2053>

PACE D. Leishmaniasis. J Infect, Nov; 69 Suppl 1: S10-8. 2014. Disponível em: <http://dx.doi.org/10.1016/j.jinf.2014.07.016>

PAI-DHUNGAT J.V; PARIKH F. Kala-Azar (Leishmaniasis). Journal of the association of physicians of índia, Mar;63(3):105-6. 2015. Disponível em: <PMID: 26543976>

PEREIRA, M. R.; ROCHA, F. S.; MELO, C. G.; MAGALHÃES, C. L. T.; CALIGIORNE, R. B. Aplicação das técnicas de Reação em Cadeia da Polimerase convencional (cPCR) e em tempo real (qPCR) para detecção do genoma Leishmania sp em amostras biológicas. Revista de Saúde Pública do SUS/MG, 1 (1), 57-58. 2013. Disponível em: <http://ISSN 2318- 2598>

RANI K.; RANA R.; DATT S. Review On Latest Overview Of Proteases. International Journal of Current Life Science. Vol.2, Issue, 1, pp. 12- 18, January, 2012. Disponivel em: <ISSN: 2249-1465>

RATHI S. K.; PANDHI R. K.; CHOPRA P.; KHANNA N. Post-kala-azar dermal leishmaniasis: a histopathological study. Indian J Dermatol Venereol Leprol. JulAug; 71(4):250-3. 2005. Disponível em: <PMID: 16394433>

RAWLINGS N. D.; BARRETT A. J.; FINN R. D. Twenty years of the MEROPS database of proteolytic enzymes, their substrates and inhibitors. Nucleic Acids Res 44, D343-D350. 2015. Disponivel em: <doi: 10.1093/nar/gkv1118> 
ROGERS L.. Preliminary note on the development of Trypanosoma in cultures of the Cunningham-Leishman-Donovan bodies of cachexial fever and kala-azar. Lanct,167:215-216,1904. Disponível em: < DOI: http://dx.doi.org/10.1016/S01406736(01)03458-4>

ROGERS M. B.; HILLEY J. D.; DICKENS N. J.; WILKES J.; BATES P. A.; DEPLEDGE D. P.; HARRIS D.; HER Y.; HERZYK P.; IMAMURA H.; OTTO T. D.; SANDERS M.; SEEGER K.; DUJARDIN J. C.; BERRIMAN M.; SMITH D. F.; HERTZ-FOWLER C.; MOTTRAM J. C. Chromosome and gene copy number variation allow major structural change between species and strains of Leishmania. Genome Res, Dec;21(12):212942. 2011. Disponível em: <doi: 10.1101/gr.122945.111.>

ROSATI S.; ORTOFFI M.; PROFITI M.; MANNELLI A.; MIGNONE W.; BOLLO E.; GRADONI L. Prokaryotic expression and antigenic characterization of three recombinant Leishmaniaantigens for serological diagnosis of canine leishmaniasis. Clin. Diagn. Lab. Immunol. 10:1153-1156. 2003. Disponível em: < doi: 10.1128/CDLI.10.6.1153-1156.2003>

ROSS, M. R.; F. R. S.; F. R. C. S.; C. B. Further notes on Leishman's bodies. The British Medical Journal, 2 (2239), 1401. 1903. Disponível em:<http://PMC2514909>

ROST B.; SANDER C. Improved prediction of protein secondary structure by use of sequence profiles and neurais networks. Proc Natl Acad Sci U S A. Aug 15; 90(16): 7558-7562. 1993b. Disponível em: <PMCID: PMC47181>

ROST B.; YACHDAV G.; LIU J. PredictProtein server Nucleic Acids Res. Nucleic Acids Res, Jul 1; 32: W321-W326. 2004. Disponível em: <doi: 10.1093/nar/gkh377>

ROST B.; SANDER C. Combining evolutionary information and neural networks to predict protein secondary structure. Proteins. May;19(1):55-72. 1994. Disponível em: <PMID: 8066087>

ROST B.; SANDER C. Prediction of protein secondary structure at better than $70 \%$ accuracy. J Mol Biol, Jul 20;232(2):584-99. 1993a. Disponível em: <PMID: 8345525>

SAMBROOK J.; RUSSELL D. W. The inoue method for preparation and transformation of competent e. Coli: "ultra-competent" cells. CSH Protoc. 2006 Jun 1. 2006. Disponivel em: <doi: 10.1101/pdb.prot3944>

SBARDELLA D.; FASCIGLIONE G. F.; GIOIA M.; CIACCIO C.; TUNDO G. R.; MARINI S.; COLETTA M. Human matrix metalloproteinases: An ubiquitarian class of enzymes involved in several pathological processes. Mol Aspects Med, Apr;33(2):119-208. 2012. Disponível em:<doi: 10.1016/j.mam.2011.10.015>

SAKKAS H.; GARTZONIKA C.; LEVIDIOTOU S. Laboratory diagnosis of human visceral leishmaniasis. J Vector Borne Dis, Jan-Mar;53(1):8-16. 2016. Disponível em: <PMID: 27004573> 
SANTOS A. L.; BRANQUINHA M. H.; D'AVILA-LEVY C. M. The ubiquitous gp63-like metalloprotease from lower trypanosomatids: in the search for a function. An Acad Bras Cienc. Dec;78(4):687-714. 2006. Disponivel em: <PMID: 17143406>

SARKARI B.; ASHRAFMANSOURI M.; HATAM G.; HABIBI P.; KHABISI A. S. Performance of an ELISA and Indirect Immunofluorescence Assay in Serological Diagnosis of Zoonotic Cutaneous Leishmaniasis in Iran. Interdiscip Perspect Infect Dis, 2014: 505134. 2014. Disponível em: <doi: 10.1155/2014/505134>

SEHGAL R.; GOYAL K.; KANWAR R.; SEHGAL A.; KANWAR J. R. Immunology of Leishmaniasis and Future Prospective of Vaccines. Intech. 2012. Disponível em: <doi: $10.5772 / 39291>$

SHIMOKATA K.; KITADA S.; OGISHIMA T.; ITO A. Role of a-Subunit of Mitochondrial Processing Peptidase in Substrate Recognition. J Biol Chem, Sep 25;273(39):2515863. 1998. Disponível em: <PMID: 9737975>

SILVERMAN J M., CHAN S. K , ROBINSON D.P, DWYER D. M., NANDAN D., FOSTER L. J.,REINER N. E. : Proteomic analysis of the secretome of Leishmania donovani. Genome Biology 2008, 9: R35. Disponível em:< doi:10.1186/gb-2008-9-2r35>

SILVERMAN J. M.; CLOS J.; DE'OLIVEIRA C. C.; SHIRVANI O.; FANG Y.; WANG C.; FOSTER L. J.; REINER N. E. An exosome-based secretion pathway is responsible for protein export from Leishmania and communication with macrophages. J Cell Sci, Mar 15;123(Pt 6):842-52. 2010. Disponível em:<doi: 10.1242/jcs.056465>

SILVERMAN J. M.; REINER N. E. Leishmania exosomes deliver preemptive strikes to create an environment permissive for early infection. Front Cell Infect Microbiol, Jan 9;1:26. 2012. Disponível em: <doi: 10.3389/fcimb.2011.00026>

SILVA JUNIOR G. B.; BARROS E. J.; DAHER EDE F. Kidney involvement in leishmaniasis--a review. Braz J Infect Dis, 18(4):434-40. 2014. Disponível em: <doi: 10.1016/j.bjid.2013.11.013>

SINGH, S. New developments in diagnosis of leishmaniasis. Review Article. Indian Journal of Medical Research, 123, 311-330. 2006. Disponível em: <http://icmr.nic.in/ijmr/2006/march/0312.pdf>

SMITH F. D.; PEACOCK S. C.; CRUZ K. A. Comparative genomics: From genotype to disease phenotype in the leishmaniases. International Journal for Parasitology, 37, 1173-1186. 2007. Disponível em: <doi: 10.1016/j.jpara.2007.05.015>

SOTO M.; REQUENA J. M.; QUIJADA L.; ALONSO C. Multicomponent chimeric antigen for serodiagnosis of canine visceral leishmaniasis. J. Clin. Microbiol. 36:5863. 1998. Disponível em: <PMCID: PMC124807> 
SOUZA, A. P.; SOTO, M.; COSTA, J. M. L.; BOAVENTURA, V. S.; OLIVEIRA, C. I.; CRISTAL, J. R.; BARRAL-NETTO, M.; BARRAL, A. Towards a More Precise Serological Diagnosis of Human Tegumentary Leishmaniasis Using Leishmania Recombinant Proteins. PLOS One, 8 (6), 2013. Disponível em: $<$ http://doi.org/10.1371/journal.pone.0066110>

TSUKAYAMA, P.; NÚÑEZ, J. H.; SANTOS, M. L.; SOBERÓN, V.; LUCAS, C. M.; MATLASHEWSKI, G.; LLANOS-CUENTAS, A.; ORE, M.; BALDEVIANO, G. C.; EDGEL, K. A.; LESCANO, A. G.; GRAF, P. C. F.; BACON, D. J. A FRET-Based RealTime PCR Assay to Identify the Main Causal Agents of New World Tegumentary Leishmaniasis. PLOS Neglected Tropical Diseases, 7 (1), 2013. Disponível em: $<$ http://doi.org/10.1371/journal.pntd.0001956>

VALLUR A. C.; REINHART C.; MOHAMATH R.; e cols. Accurate serodetection of asymptomatic Leishmania donovani infection by use of defined antigens. J Clin Microbiol 54:1025-1030. 2016. Disponivel em:<doi:10.1128/JCM.02620-15.>

VERMELHO A. B.; BRANQUINHA M. H.; D'AVILA-LEVY C. M.; SANTOS A. L. S.; DIAS E. P. S.; MELO A. C. N. Biological Roles of Peptidases in Trypanosomatids. The Open Parasitology Journal, 4, 5-23. The Open Parasitology Journal, 2010, 4, 5-23. Disponivel em: <ISSN 1874-4214/10>

VILJOEN G. J.; NEL L. H.; CROWTHER J. R.; Molecular Diagnostic PCR Handbook. Netherlands, Springer 2005, 325 paginas.

VINCZE .; POSFAI J.; ROBERTS R. J. NEBcutter: a program to cleave DNA with restriction enzymes. Oxford Journals, Nucleic Acids Research Vol 31, Issue 13 Pp. 3688-3691. 2003. Disponível em: <PMID: 12824395>

WALLER R. F.; MCCONVILLE M. J. Developmental changes in lysosome morphology and function Leishmania parasites. Int $\mathbf{J}$ Parasitol, Nov; 32(12):1435-45. 2002. Disponível em: <PMID: 12392909>

WEN, Y.; YAN X.; WEN P. e cols. Immunogenicity of the recombinant HxuCBA proteins encoded by hxuCBA gene cluster of Haemophilus parasuis in mice, Gene Disponível em: <doi.org/10.1016/j.gene.2016.07.001>

WIJEYARATNE P.M; ARSENAULT L.K.J; MURPHY C.J. Endemic disease and development: the leishmaniases. Acta. Tropica, 56, 349-364. 1994. Disponível em: <doi:10.1016/0001-706X(94)90106-6>

WORLD HEALTH ORGANIZATION (WHO). Leishmaniasis. Fact sheet 2016. Acessado em 04 de abril de 2016a. Disponível em: <http://www.who.int/mediacentre/factsheets/fs375/en/. >

WORLD HEALTH ORGANIZATION (WHO). Leishmaniasis. Acessado em 04 de abril de 2016b. Disponível em: <http://www.who.int/leishmaniasis/burden/en/>

WORLD HEALTH ORGANIZATION (WHO). Technical Report Series. Control of the leishmaniases: report of a meeting of the WHO Expert Committee on the Control 
of Leishmaniases. Geneva, 22-26, March 2010. Disponível em: <http://apps.who.int/iris/bitstream/10665/44412/1/WHO_TRS_949_eng.pdf>

WRIGHT, J. H. Protozoa in a case of tropical ulcer ("Delhi sore"). Journal of Medical Research, 10 (3), 472-482.7. 1904. Disponível em: <http://PMC2105980>

ZAPPACOSTA R.; CLAUDI R.; MAGNASCO S.; DELL'OSA E. Leishmania life cycle images in the cutaneous cytologic smear of an immunocompetent patient. J Cytol, Jan; 27 (1):35-6. 2010. Disponível em: <doi: 10.4103/0970-9371.66695> 


\section{APÊNDICES}

Apêndice A: Predição de epitopos lineares para células B. O ponto de corte padrão para definição de um aminoácido dentro de um epitopo é de 0,35 , pela ferramenta Bepipred. Os dados, referentes à coluna indicada por "?" indicam pela letra "E" quando o aminoácido é previsto como sendo parte de um epitopo linear de célula B (pontuação acima do limiar) e "." como sendo região não pertencente a epitopos (pontuação abaixo do limiar). Para uma análise conveniente, os dados foram precedidos pelos símbolos de seus respectivos aminoácidos seguida por um '|' (barra vertical). No total 219 aminoácidos foram incluídos em possíveis epitopos lineares para células $\mathrm{B}$, equivalente a $41 \%$ dos aminoácidos da proteína.

\begin{tabular}{|c|c|c|c|c|c|c|c|}
\hline \# SEQNAME & SOURCE & FEATURE & START & END & SCORE & $\mathrm{N} / \mathrm{A}$ & ? \\
\hline 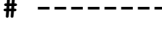 & & & & & & & \\
\hline QUERY & BEPIPRED-1.0B & EPITOPE & 8 & 8 & 0.500 & .. & $\mathrm{P} \mid \mathrm{E}$ \\
\hline QUERY & BEPIPRED-1.0B & EPITOPE & 9 & 9 & 0.597 & . . & $\mathrm{A} \mid \mathrm{E}$ \\
\hline QUERY & BEPIPRED-1.0B & EPITOPE & 10 & 10 & 0.927 & . . & $\mathrm{P} \mid \mathrm{E}$ \\
\hline QUERY & BEPIPRED-1.0B & EPITOPE & 11 & 11 & 0.974 & . . & $\mathrm{V} \mid \mathrm{E}$ \\
\hline QUERY & BEPIPRED-1. OB & EPITOPE & 12 & 12 & 0.900 & . . & $A \mid E$ \\
\hline QUERY & BEPIPRED-1.0B & EPITOPE & 13 & 13 & 0.686 & . . & $\mathrm{A} \mid \mathrm{E}$ \\
\hline QUERY & BEPIPRED-1.0B & EPITOPE & 14 & 14 & 0.503 & . . & $T \mid E$ \\
\hline QUERY & BEPIPRED-1.0B & EPITOPE & 15 & 15 & 0.389 & . . & $\mathbf{A} \mid \mathbf{E}$ \\
\hline QUERY & BEPIPRED-1.0B & EPITOPE & 16 & 16 & 0.557 & . . & $\mathrm{A} \mid \mathrm{E}$ \\
\hline QUERY & BEPIPRED-1.0B & EPITOPE & 17 & 17 & 0.527 & . . & $\mathrm{C} \mid \mathrm{E}$ \\
\hline QUERY & BEPIPRED-1.0B & EPITOPE & 18 & 18 & 0.562 & . . & $\mathrm{A} \mid \mathrm{E}$ \\
\hline QUERY & BEPIPRED-1.0B & EPITOPE & 19 & 19 & 0.477 & . . & $\mathrm{G} \mid \mathrm{E}$ \\
\hline QUERY & BEPIPRED-1.0B & EPITOPE & 29 & 29 & 0.443 & . . & $\mathbf{F} \mid \mathbf{E}$ \\
\hline QUERY & BEPIPRED-1.0B & EPITOPE & 30 & 30 & 0.417 & . . & $G \mid E$ \\
\hline QUERY & BEPIPRED-1.0B & EPITOPE & 31 & 31 & 0.608 & . . & QIE \\
\hline QUERY & BEPIPRED-1.0B & EPITOPE & 32 & 32 & 0.851 & . . & $\mathbf{T} \mid \mathbf{E}$ \\
\hline QUERY & BEPIPRED-1.0B & EPITOPE & 33 & 33 & 0.909 & . . & $\mathrm{P} \mid \mathrm{E}$ \\
\hline QUERY & BEPIPRED-1.0B & EPITOPE & 34 & 34 & 1.065 & . . & $L \mid E$ \\
\hline QUERY & BEPIPRED-1.0B & EPITOPE & 35 & 35 & 1.192 & . . & $\mathbf{T} \mid \mathbf{E}$ \\
\hline QUERY & BEPIPRED-1.0B & EPITOPE & 36 & 36 & 1.129 & . . & QIE \\
\hline QUERY & BEPIPRED-1.0B & EPITOPE & 37 & 37 & 1.124 & . . & $\mathrm{P} \mid \mathrm{E}$ \\
\hline QUERY & BEPIPRED-1.0B & EPITOPE & 38 & 38 & 1.130 & . . & $F \mid E$ \\
\hline QUERY & BEPIPRED-1.0B & EPITOPE & 39 & 39 & 1.386 & . . & $G \mid E$ \\
\hline QUERY & BEPIPRED-1.0B & EPITOPE & 40 & 40 & 1.047 & . . & $\mathbf{G} \mid \mathbf{E}$ \\
\hline QUERY & BEPIPRED-1.0B & EPITOPE & 41 & 41 & 1.110 & . . & $\mathbf{T} \mid \mathbf{E}$ \\
\hline QUERY & BEPIPRED-1.0B & EPITOPE & 42 & 42 & 1.283 & . . & $S \mid E$ \\
\hline QUERY & BEPIPRED-1.0B & EPITOPE & 43 & 43 & 1.821 & . . & $R \mid E$ \\
\hline QUERY & BEPIPRED-1.0B & EPITOPE & 44 & 44 & 1.886 & . . & $L \mid E$ \\
\hline QUERY & BEPIPRED-1.0B & EPITOPE & 45 & 45 & 2.027 & . . & $\mathrm{P} \mid \mathrm{E}$ \\
\hline QUERY & BEPIPRED-1.0B & EPITOPE & 46 & 46 & 2.196 & . . & $P \mid E$ \\
\hline QUERY & BEPIPRED-1.0B & EPITOPE & 47 & 47 & 2.319 & . . & $G \mid E$ \\
\hline QUERY & BEPIPRED-1.0B & EPITOPE & 48 & 48 & 2.452 & . . & $\mathrm{P} \mid \mathrm{E}$ \\
\hline QUERY & BEPIPRED-1.0B & EPITOPE & 49 & 49 & 2.706 & . . & $\mathrm{S} \mid \mathrm{E}$ \\
\hline QUERY & BEPIPRED-1.0B & EPITOPE & 50 & 50 & 2.735 & . . & $S \mid E$ \\
\hline QUERY & BEPIPRED-1.0B & EPITOPE & 51 & 51 & 2.426 & . . & $\mathrm{K} \mid \mathrm{E}$ \\
\hline QUERY & BEPIPRED-1.0B & EPITOPE & 52 & 52 & 2.085 & . . & $\mathrm{P} \mid \mathrm{E}$ \\
\hline QUERY & BEPIPRED-1.0B & EPITOPE & 53 & 53 & 1.801 & . . & $\mathrm{A} \mid \mathrm{E}$ \\
\hline QUERY & BEPIPRED-1.0B & EPITOPE & 54 & 54 & 1.621 & . . & $P \mid E$ \\
\hline QUERY & BEPIPRED-1.0B & EPITOPE & 55 & 55 & 1.391 & . . & $\mathrm{V} \mid \mathrm{E}$ \\
\hline QUERY & BEPIPRED-1.0B & EPITOPE & 56 & 56 & 1.034 & . . & $\mathrm{A} \mid \mathrm{E}$ \\
\hline QUERY & BEPIPRED-1.0B & EPITOPE & 57 & 57 & 0.870 & . . & $A \mid E$ \\
\hline QUERY & BEPIPRED-1.0B & EPITOPE & 58 & 58 & 0.460 & . . & $\mathrm{G} \mid \mathrm{E}$ \\
\hline QUERY & BEPIPRED-1.0B & EPITOPE & 76 & 76 & 0.538 & . . & $L \mid E$ \\
\hline QUERY & BEPIPRED-1.0B & EPITOPE & 77 & 77 & 0.797 & . . & $G \mid E$ \\
\hline QUERY & BEPIPRED-1.0B & EPITOPE & 78 & 78 & 0.887 & . . & $\mathbf{G} \mid \mathbf{E}$ \\
\hline QUERY & BEPIPRED-1.0B & EPITOPE & 79 & 79 & 0.857 & . . & $\mathrm{P} \mid \mathrm{E}$ \\
\hline QUERY & BEPIPRED-1.0B & EPITOPE & 80 & 80 & 0.865 & . . & $S \mid E$ \\
\hline QUERY & BEPIPRED-1.0B & EPITOPE & 81 & 81 & 1.022 & . . & $\mathrm{V} \mid \mathrm{E}$ \\
\hline QUERY & BEPIPRED-1.0B & EPITOPE & 82 & 82 & 0.655 & . . & $\mathrm{S} \mid \mathrm{E}$ \\
\hline QUERY & BEPIPRED-1.0B & EPITOPE & 90 & 90 & 0.491 & . . & $\mathrm{G} \mid \mathrm{E}$ \\
\hline QUERY & BEPIPRED-1.0B & EPITOPE & 91 & 91 & 0.882 & . . & $P \mid E$ \\
\hline QUERY & BEPIPRED-1.0B & EPITOPE & 92 & 92 & 1.475 & . . & $\mathrm{A} \mid \mathrm{E}$ \\
\hline QUERY & BEPIPRED-1.0B & EPITOPE & 93 & 93 & 2.236 & . . & $\mathrm{Y} \mid \mathrm{E}$ \\
\hline QUERY & BEPIPRED-1.0B & EPITOPE & 94 & 94 & 2.469 & . . & $\mathrm{D} \mid \mathrm{E}$ \\
\hline QUERY & BEPIPRED-1.0B & EPITOPE & 95 & 95 & 2.480 & . . & $\mathrm{P} \mid \mathrm{E}$ \\
\hline QUERY & BEPIPRED-1.0B & EPITOPE & 96 & 96 & 2.608 & . . & $P \mid E$ \\
\hline QUERY & BEPIPRED-1.0B & EPITOPE & 97 & 97 & 2.733 & . . & $S \mid E$ \\
\hline
\end{tabular}




\begin{tabular}{|c|c|c|c|c|c|c|c|}
\hline QUERY & BEPIPRED $-1.0 \mathrm{~B}$ & EPITOPE & 98 & 98 & 2.716 & & $A \mid E$ \\
\hline QUERY & BEPIPRED $-1.0 \mathrm{~B}$ & EPITOPE & 99 & 99 & 2.276 & . . & P|E \\
\hline QUERY & BEPIPRED-1.0B & EPITOPE & 100 & 100 & 1.848 & . & G|E \\
\hline QUERY & BEPIPRED $-1.0 \mathrm{~B}$ & EPITOPE & 101 & 101 & 1.278 & . & $T \mid E$ \\
\hline QUERY & BEPIPRED-1.0B & EPITOPE & 102 & 102 & 0.669 & . & G|E \\
\hline QUERY & BEPIPRED-1.0B & EPITOPE & 112 & 112 & 0.406 & . & S|E \\
\hline QUERY & BEPIPRED $-1.0 \mathrm{~B}$ & EPITOPE & 113 & 113 & 0.564 & . & $\mathbf{N} \mid \mathbf{E}$ \\
\hline QUERY & BEPIPRED $-1.0 \mathrm{~B}$ & EPITOPE & 114 & 114 & 0.575 & . . & Y|E \\
\hline QUERY & BEPIPRED-1.0B & EPITOPE & 130 & 130 & 0.575 & . . & $\mathbf{A} \mid \mathbf{E}$ \\
\hline QUERY & BEPIPRED $-1.0 \mathrm{~B}$ & EPITOPE & 132 & 132 & 0.368 & . . & Q|E \\
\hline QUERY & BEPIPRED-1.0B & EPITOPE & 133 & 133 & 0.511 & . . & $S \mid E$ \\
\hline QUERY & BEPIPRED-1.0B & EPITOPE & 134 & 134 & 0.395 & . . & $\mathrm{H} \mid \mathrm{E}$ \\
\hline QUERY & BEPIPRED $-1.0 \mathrm{~B}$ & EPITOPE & 135 & 135 & 0.405 & . & $F \mid E$ \\
\hline QUERY & BEPIPRED $-1.0 \mathrm{~B}$ & EPITOPE & 149 & 149 & 0.394 & . . & R/E \\
\hline QUERY & BEPIPRED $-1.0 \mathrm{~B}$ & EPITOPE & 150 & 150 & 0.496 & $\therefore$ & A $\mid \mathbf{E}$ \\
\hline QUERY & BEPIPRED $-1.0 \mathrm{~B}$ & EPITOPE & 151 & 151 & 0.906 & . . & D $\mid E$ \\
\hline QUERY & BEPIPRED-1.0B & EPITOPE & 152 & 152 & 0.901 & . . & $\mathrm{K} \mid \mathrm{E}$ \\
\hline QUERY & BEPIPRED $-1.0 \mathrm{~B}$ & EPITOPE & 153 & 153 & 1.065 & . . & $\mathrm{W} \mid \mathrm{E}$ \\
\hline QUERY & BEPIPRED-1.0B & EPITOPE & 154 & 154 & 1.104 & . . & $\mathrm{K} \mid \mathrm{E}$ \\
\hline QUERY & BEPIPRED $-1.0 \mathrm{~B}$ & EPITOPE & 155 & 155 & 1.308 & . . & S|E \\
\hline QUERY & BEPIPRED-1.0B & EPITOPE & 156 & 156 & 1.295 & . . & $\mathbf{A} \mid \mathbf{E}$ \\
\hline QUERY & BEPIPRED $-1.0 \mathrm{~B}$ & EPITOPE & 157 & 157 & 1.270 & . . & $\mathbf{A} \mid \mathbf{E}$ \\
\hline QUERY & BEPIPRED-1.0B & EPITOPE & 158 & 158 & 1.216 & . . & $\mathrm{P} \mid \mathrm{E}$ \\
\hline QUERY & BEPIPRED $-1.0 \mathrm{~B}$ & EPITOPE & 159 & 159 & 1.174 & . . & $T \mid E$ \\
\hline QUERY & BEPIPRED-1.0B & EPITOPE & 160 & 160 & 1.073 & . . & S|E \\
\hline QUERY & BEPIPRED $-1.0 \mathrm{~B}$ & EPITOPE & 161 & 161 & 1.017 & . . & $\mathrm{S} \mid \mathrm{E}$ \\
\hline QUERY & BEPIPRED $-1.0 \mathrm{~B}$ & EPITOPE & 162 & 162 & 0.874 & . . & L|E \\
\hline QUERY & BEPIPRED $-1.0 \mathrm{~B}$ & EPITOPE & 163 & 163 & 0.744 & . . & S|E \\
\hline QUERY & BEPIPRED-1.0B & EPITOPE & 167 & 167 & 0.511 & . . & QIE \\
\hline QUERY & BEPIPRED $-1.0 \mathrm{~B}$ & EPITOPE & 168 & 168 & 0.578 & . . & $\mathrm{L} \mid \mathrm{E}$ \\
\hline QUERY & BEPIPRED-1.0B & EPITOPE & 169 & 169 & 0.698 & . . & Q|E \\
\hline QUERY & BEPIPRED $-1.0 \mathrm{~B}$ & EPITOPE & 170 & 170 & 0.680 & . . & $\mathrm{N} \mid \mathrm{E}$ \\
\hline QUERY & BEPIPRED-1.0B & EPITOPE & 171 & 171 & 0.888 & . . & $Q \mid E$ \\
\hline QUERY & BEPIPRED $-1.0 \mathrm{~B}$ & EPITOPE & 172 & 172 & 0.953 & . . & $\mathrm{K} \mid \mathbf{E}$ \\
\hline QUERY & BEPIPRED-1.0B & EPITOPE & 173 & 173 & 1.318 & . . & QIE \\
\hline QUERY & BEPIPRED $-1.0 \mathrm{~B}$ & EPITOPE & 174 & 174 & 0.944 & . . & $\mathbf{A} \mid \mathbf{E}$ \\
\hline QUERY & BEPIPRED-1.0B & EPITOPE & 175 & 175 & 0.875 & . . & $\mathbf{E} \mid \mathbf{E}$ \\
\hline QUERY & BEPIPRED $-1.0 \mathrm{~B}$ & EPITOPE & 176 & 176 & 0.354 & . . & Q|E \\
\hline QUERY & BEPIPRED $-1.0 \mathrm{~B}$ & EPITOPE & 196 & 196 & 0.905 & . . & $\boldsymbol{F} \mid \mathbf{E}$ \\
\hline QUERY & BEPIPRED $-1.0 \mathrm{~B}$ & EPITOPE & 197 & 197 & 0.923 & . . & $\mathrm{H} \mid \mathrm{E}$ \\
\hline QUERY & BEPIPRED $-1.0 \mathrm{~B}$ & EPITOPE & 198 & 198 & 0.962 & . . & $E \mid E$ \\
\hline QUERY & BEPIPRED $-1.0 \mathrm{~B}$ & EPITOPE & 199 & 199 & 0.852 & . & P|E \\
\hline QUERY & BEPIPRED-1.0B & EPITOPE & 200 & 200 & 0.526 & . & $\mathrm{D} \mid \mathrm{E}$ \\
\hline QUERY & BEPIPRED $-1.0 \mathrm{~B}$ & EPITOPE & 201 & 201 & 0.723 & . . & $\mathrm{V} \mid \mathrm{E}$ \\
\hline QUERY & BEPIPRED $-1.0 \mathrm{~B}$ & EPITOPE & 202 & 202 & 0.772 & . & $\mathbf{E} \mid \mathbf{E}$ \\
\hline QUERY & BEPIPRED $-1.0 \mathrm{~B}$ & EPITOPE & 203 & 203 & 0.649 & 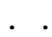 & $\mathrm{R} \mid \mathrm{E}$ \\
\hline QUERY & BEPIPRED $-1.0 \mathrm{~B}$ & EPITOPE & 204 & 204 & 0.383 & . . & $F \mid E$ \\
\hline QUERY & BEPIPRED $-1.0 \mathrm{~B}$ & EPITOPE & 207 & 207 & 0.392 & . & $\mathbf{T} \mid \mathrm{E}$ \\
\hline QUERY & BEPIPRED-1.0B & EPITOPE & 208 & 208 & 0.363 & . & I|E \\
\hline QUERY & BEPIPRED $-1.0 \mathrm{~B}$ & EPITOPE & 209 & 209 & 0.697 & . . & $\mathrm{D} \mid \mathrm{E}$ \\
\hline QUERY & BEPIPRED-1.0B & EPITOPE & 210 & 210 & 0.731 & . & $\mathbf{N} \mid \mathbf{E}$ \\
\hline QUERY & BEPIPRED $-1.0 \mathrm{~B}$ & EPITOPE & 211 & 211 & 0.373 & 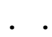 & Q|E \\
\hline QUERY & BEPIPRED-1.0B & EPITOPE & 220 & 220 & 0.379 & . . & $\mathrm{P} \mid \mathrm{E}$ \\
\hline QUERY & BEPIPRED $-1.0 \mathrm{~B}$ & EPITOPE & 221 & 221 & 0.405 & . . & $\mathbf{A} \mid \mathbf{E}$ \\
\hline QUERY & BEPIPRED-1.0B & EPITOPE & 222 & 222 & 0.768 & . & $E \mid E$ \\
\hline QUERY & BEPIPRED $-1.0 \mathrm{~B}$ & EPITOPE & 223 & 223 & 0.461 & . . & $\mathrm{Y} \mid \mathrm{E}$ \\
\hline QUERY & BEPIPRED-1.0B & EPITOPE & 236 & 236 & 0.363 & . & $\mathbf{E} \mid \mathbf{E}$ \\
\hline QUERY & BEPIPRED $-1.0 \mathrm{~B}$ & EPITOPE & 237 & 237 & 0.568 & . & P|E \\
\hline QUERY & BEPIPRED $-1.0 \mathrm{~B}$ & EPITOPE & 238 & 238 & 0.966 & . . & L|E \\
\hline QUERY & BEPIPRED $-1.0 \mathrm{~B}$ & EPITOPE & 239 & 239 & 0.970 & . . & G|E \\
\hline QUERY & BEPIPRED-1.0B & EPITOPE & 240 & 240 & 0.774 & . & $\mathrm{N} \mid \mathrm{E}$ \\
\hline QUERY & BEPIPRED $-1.0 \mathrm{~B}$ & EPITOPE & 241 & 241 & 0.603 & . . & $\mathrm{P} \mid \mathrm{E}$ \\
\hline QUERY & BEPIPRED-1.0B & EPITOPE & 242 & 242 & 0.538 & . . & $\mathbf{R} \mid \mathbf{E}$ \\
\hline QUERY & BEPIPRED $-1.0 \mathrm{~B}$ & EPITOPE & 243 & 243 & 0.629 & . & $F \mid E$ \\
\hline QUERY & BEPIPRED $-1.0 \mathrm{~B}$ & EPITOPE & 244 & 244 & 0.463 & . . & $\mathrm{V} \mid \mathrm{E}$ \\
\hline QUERY & BEPIPRED $-1.0 \mathrm{~B}$ & EPITOPE & 286 & 286 & 0.391 & . & $\mathrm{Y} \mid \mathrm{E}$ \\
\hline QUERY & BEPIPRED-1.0B & EPITOPE & 287 & 287 & 0.630 & . & $E \mid E$ \\
\hline QUERY & BEPIPRED $-1.0 \mathrm{~B}$ & EPITOPE & 288 & 288 & 1.069 & . . & $\mathrm{N} \mid \mathrm{E}$ \\
\hline QUERY & BEPIPRED-1.0B & EPITOPE & 289 & 289 & 1.252 & . . & $T \mid E$ \\
\hline QUERY & BEPIPRED $-1.0 \mathrm{~B}$ & EPITOPE & 290 & 290 & 1.371 & . . & $\mathrm{P} \mid \mathrm{E}$ \\
\hline QUERY & BEPIPRED $-1.0 \mathrm{~B}$ & EPITOPE & 291 & 291 & 1.420 & . & $\mathbf{F} \mid \mathbf{E}$ \\
\hline QUERY & BEPIPRED $-1.0 \mathrm{~B}$ & EPITOPE & 292 & 292 & 1.494 & . . & P|E \\
\hline QUERY & BEPIPRED $-1.0 \mathrm{~B}$ & EPITOPE & 293 & 293 & 1.359 & . & $\mathrm{H} \mid \mathrm{E}$ \\
\hline QUERY & BEPIPRED $-1.0 \mathrm{~B}$ & EPITOPE & 294 & 294 & 1.294 & . & $\mathrm{S} \mid \mathrm{E}$ \\
\hline QUERY & BEPIPRED-1.0B & EPITOPE & 295 & 295 & 1.205 &. & $\mathbf{A} \mid \mathbf{E}$ \\
\hline QUERY & BEPIPRED $-1.0 \mathrm{~B}$ & EPITOPE & 296 & 296 & 1.358 & . . & $\mathrm{S} \mid \mathrm{E}$ \\
\hline
\end{tabular}




\begin{tabular}{|c|c|c|c|c|c|c|c|}
\hline QUERY & BEPIPRED $-1.0 \mathrm{~B}$ & EPITOPE & 297 & 297 & 1.145 & & $\mathbf{A} \mid \mathbf{E}$ \\
\hline QUERY & BEPIPRED $-1.0 \mathrm{~B}$ & EPITOPE & 298 & 298 & 1.124 & . & P|E \\
\hline QUERY & BEPIPRED-1.0B & EPITOPE & 299 & 299 & 1.002 & . & $\mathrm{H} \mid \mathrm{E}$ \\
\hline QUERY & BEPIPRED $-1.0 \mathrm{~B}$ & EPITOPE & 300 & 300 & 1.104 & . & $\mathrm{H} \mid \mathrm{E}$ \\
\hline QUERY & BEPIPRED-1.0B & EPITOPE & 301 & 301 & 0.924 & . & $\mathbf{A} \mid \mathbf{E}$ \\
\hline QUERY & BEPIPRED $-1.0 \mathrm{~B}$ & EPITOPE & 302 & 302 & 0.827 & . & $\mathrm{R} \mid \mathrm{E}$ \\
\hline QUERY & BEPIPRED $-1.0 \mathrm{~B}$ & EPITOPE & 303 & 303 & 0.731 & r & $\mathbf{A} \mid \mathbf{E}$ \\
\hline QUERY & BEPIPRED $-1.0 \mathrm{~B}$ & EPITOPE & 304 & 304 & 0.439 & . . & Q|E \\
\hline QUERY & BEPIPRED-1.0B & EPITOPE & 305 & 305 & 0.464 & . . & $\mathrm{P} \mid \mathrm{E}$ \\
\hline QUERY & BEPIPRED $-1.0 \mathrm{~B}$ & EPITOPE & 307 & 307 & 0.393 & . . & $\mathbf{A} \mid \mathbf{E}$ \\
\hline QUERY & BEPIPRED-1.0B & EPITOPE & 308 & 308 & 0.522 & . . & $\mathrm{V} \mid \mathrm{E}$ \\
\hline QUERY & BEPIPRED $-1.0 \mathrm{~B}$ & EPITOPE & 309 & 309 & 0.599 & $\therefore$ & $\mathbf{N} \mid \mathbf{E}$ \\
\hline QUERY & BEPIPRED $-1.0 \mathrm{~B}$ & EPITOPE & 310 & 310 & 0.599 & . . & $\mathbf{W} \mid \mathbf{E}$ \\
\hline QUERY & BEPIPRED $-1.0 \mathrm{~B}$ & EPITOPE & 311 & 311 & 0.616 & . . & $\mathrm{K} \mid \mathrm{E}$ \\
\hline QUERY & BEPIPRED $-1.0 \mathrm{~B}$ & EPITOPE & 312 & 312 & 0.728 & $\therefore$ & D $\mid E$ \\
\hline QUERY & BEPIPRED $-1.0 \mathrm{~B}$ & EPITOPE & 313 & 313 & 0.900 & . . & $E \mid E$ \\
\hline QUERY & BEPIPRED-1.0B & EPITOPE & 314 & 314 & 0.950 & . . & $\mathrm{A} \mid \mathrm{E}$ \\
\hline QUERY & BEPIPRED $-1.0 \mathrm{~B}$ & EPITOPE & 315 & 315 & 1.345 & . . & $\mathbf{A} \mid \mathbf{E}$ \\
\hline QUERY & BEPIPRED-1.0B & EPITOPE & 316 & 316 & 1.383 & . . & Q|E \\
\hline QUERY & BEPIPRED $-1.0 \mathrm{~B}$ & EPITOPE & 317 & 317 & 1.352 & . . & Y|E \\
\hline QUERY & BEPIPRED-1.0B & EPITOPE & 318 & 318 & 1.273 & . . & $T \mid E$ \\
\hline QUERY & BEPIPRED $-1.0 \mathrm{~B}$ & EPITOPE & 319 & 319 & 1.218 & . . & $\mathrm{G} \mid \mathrm{E}$ \\
\hline QUERY & BEPIPRED-1.0B & EPITOPE & 320 & 320 & 1.369 & $\therefore$ & G IE \\
\hline QUERY & BEPIPRED $-1.0 \mathrm{~B}$ & EPITOPE & 321 & 321 & 1.310 & . . & $E \mid E$ \\
\hline QUERY & BEPIPRED-1.0B & EPITOPE & 322 & 322 & 1.509 & . . & $\mathrm{R} \mid \mathrm{E}$ \\
\hline QUERY & BEPIPRED $-1.0 \mathrm{~B}$ & EPITOPE & 323 & 323 & 1.654 & . . & $\mathrm{H} \mid \mathrm{E}$ \\
\hline QUERY & BEPIPRED $-1.0 \mathrm{~B}$ & EPITOPE & 324 & 324 & 1.668 & . . & $\mathrm{D} \mid \mathrm{E}$ \\
\hline QUERY & BEPIPRED $-1.0 \mathrm{~B}$ & EPITOPE & 325 & 325 & 1.574 & . . & H|E \\
\hline QUERY & BEPIPRED-1.0B & EPITOPE & 326 & 326 & 1.451 & . . & $E \mid E$ \\
\hline QUERY & BEPIPRED $-1.0 \mathrm{~B}$ & EPITOPE & 327 & 327 & 1.269 & . . & D|E \\
\hline QUERY & BEPIPRED-1.0B & EPITOPE & 328 & 328 & 1.098 & . . & $\mathbf{R} \mid \mathbf{E}$ \\
\hline QUERY & BEPIPRED-1.0B & EPITOPE & 329 & 329 & 0.973 & $\therefore$ & $\mathrm{P} \mid \mathrm{E}$ \\
\hline QUERY & BEPIPRED $-1.0 \mathrm{~B}$ & EPITOPE & 330 & 330 & 1.094 & . . & $\mathbf{K} \mid \mathbf{E}$ \\
\hline QUERY & BEPIPRED $-1.0 \mathrm{~B}$ & EPITOPE & 331 & 331 & 1.194 & . . & $\mathrm{V} \mid \mathrm{E}$ \\
\hline QUERY & BEPIPRED-1.0B & EPITOPE & 332 & 332 & 1.008 & . . & $\mathrm{M} \mid \mathrm{E}$ \\
\hline QUERY & BEPIPRED $-1.0 \mathrm{~B}$ & EPITOPE & 333 & 333 & 1.104 & . . & $\mathbf{G} \mid \mathrm{E}$ \\
\hline QUERY & BEPIPRED-1.0B & EPITOPE & 334 & 334 & 1.107 & . . & $T \mid E$ \\
\hline QUERY & BEPIPRED $-1.0 \mathrm{~B}$ & EPITOPE & 335 & 335 & 1.322 & . . & $\mathrm{K} \mid \mathrm{E}$ \\
\hline QUERY & BEPIPRED $-1.0 \mathrm{~B}$ & EPITOPE & 336 & 336 & 1.510 & . . & P|E \\
\hline QUERY & BEPIPRED $-1.0 \mathrm{~B}$ & EPITOPE & 337 & 337 & 1.912 & . . & $\mathrm{D} \mid \mathrm{E}$ \\
\hline QUERY & BEPIPRED $-1.0 \mathrm{~B}$ & EPITOPE & 338 & 338 & 1.999 & $\therefore$ & $\mathbf{M} \mid \mathbf{E}$ \\
\hline QUERY & BEPIPRED $-1.0 \mathrm{~B}$ & EPITOPE & 339 & 339 & 1.560 & . & $\mathrm{D} \mid \mathrm{E}$ \\
\hline QUERY & BEPIPRED-1.0B & EPITOPE & 340 & 340 & 0.965 & . & $\mathrm{P} \mid \mathrm{E}$ \\
\hline QUERY & BEPIPRED $-1.0 \mathrm{~B}$ & EPITOPE & 341 & 341 & 0.741 & . . & $E \mid E$ \\
\hline QUERY & BEPIPRED $-1.0 \mathrm{~B}$ & EPITOPE & 354 & 354 & 0.599 & . & $D \mid E$ \\
\hline QUERY & BEPIPRED $-1.0 \mathrm{~B}$ & EPITOPE & 355 & 355 & 0.716 & 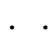 & $\mathrm{R} \mid \mathrm{E}$ \\
\hline QUERY & BEPIPRED $-1.0 \mathrm{~B}$ & EPITOPE & 356 & 356 & 1.029 & $\therefore$ & $\mathrm{K} \mid \mathrm{E}$ \\
\hline QUERY & BEPIPRED $-1.0 \mathrm{~B}$ & EPITOPE & 357 & 357 & 0.926 & . & $\mathbf{M} \mid \mathbf{E}$ \\
\hline QUERY & BEPIPRED-1.0B & EPITOPE & 358 & 358 & 0.832 & - & $T \mid E$ \\
\hline QUERY & BEPIPRED $-1.0 \mathrm{~B}$ & EPITOPE & 359 & 359 & 0.542 & . . & $\mathrm{K} \mid \mathrm{E}$ \\
\hline QUERY & BEPIPRED-1.0B & EPITOPE & 360 & 360 & 0.556 & . & $D \mid E$ \\
\hline QUERY & BEPIPRED $-1.0 \mathrm{~B}$ & EPITOPE & 380 & 380 & 0.492 & . & $R \mid E$ \\
\hline QUERY & BEPIPRED-1.0B & EPITOPE & 381 & 381 & 0.648 & . . & $\mathrm{C} \mid \mathrm{E}$ \\
\hline QUERY & BEPIPRED $-1.0 \mathrm{~B}$ & EPITOPE & 382 & 382 & 0.835 & . . & $G \mid E$ \\
\hline QUERY & BEPIPRED-1.0B & EPITOPE & 383 & 383 & 0.692 & . & $\mathrm{A} \mid \mathrm{E}$ \\
\hline QUERY & BEPIPRED $-1.0 \mathrm{~B}$ & EPITOPE & 384 & 384 & 0.885 & . . & $\mathrm{P} \mid \mathrm{E}$ \\
\hline QUERY & BEPIPRED-1.0B & EPITOPE & 385 & 385 & 1.026 & . . & $D \mid E$ \\
\hline QUERY & BEPIPRED $-1.0 \mathrm{~B}$ & EPITOPE & 386 & 386 & 1.168 & . & $E \mid E$ \\
\hline QUERY & BEPIPRED $-1.0 \mathrm{~B}$ & EPITOPE & 387 & 387 & 1.081 & . . & $\mathbf{M} \mid \mathbf{E}$ \\
\hline QUERY & BEPIPRED $-1.0 \mathrm{~B}$ & EPITOPE & 388 & 388 & 1.029 & . . & H|E \\
\hline QUERY & BEPIPRED-1.0B & EPITOPE & 389 & 389 & 0.567 & . & $E \mid E$ \\
\hline QUERY & BEPIPRED $-1.0 \mathrm{~B}$ & EPITOPE & 398 & 398 & 0.384 & . . & $\mathrm{S} \mid \mathrm{E}$ \\
\hline QUERY & BEPIPRED-1.0B & EPITOPE & 399 & 399 & 0.408 & . . & P|E \\
\hline QUERY & BEPIPRED $-1.0 \mathrm{~B}$ & EPITOPE & 400 & 400 & 0.586 & . & Y|E \\
\hline QUERY & BEPIPRED $-1.0 \mathrm{~B}$ & EPITOPE & 401 & 401 & 0.603 & . . & $Q \mid E$ \\
\hline QUERY & BEPIPRED $-1.0 \mathrm{~B}$ & EPITOPE & 410 & 410 & 0.444 & . & $\mathbf{A} \mid \mathbf{E}$ \\
\hline QUERY & BEPIPRED-1.0B & EPITOPE & 411 & 411 & 0.977 & . & $\mathrm{K} \mid \mathrm{E}$ \\
\hline QUERY & BEPIPRED $-1.0 \mathrm{~B}$ & EPITOPE & 412 & 412 & 1.096 & . . & $\mathbf{A} \mid \mathbf{E}$ \\
\hline QUERY & BEPIPRED-1.0B & EPITOPE & 413 & 413 & 1.327 & . . & $E \mid E$ \\
\hline QUERY & BEPIPRED $-1.0 \mathrm{~B}$ & EPITOPE & 414 & 414 & 1.037 & . . & $\mathrm{P} \mid \mathrm{E}$ \\
\hline QUERY & BEPIPRED $-1.0 \mathrm{~B}$ & EPITOPE & 415 & 415 & 0.973 & . & Q|E \\
\hline QUERY & BEPIPRED $-1.0 \mathrm{~B}$ & EPITOPE & 416 & 416 & 0.583 & . . & $\mathbf{A} \mid \mathbf{E}$ \\
\hline QUERY & BEPIPRED $-1.0 \mathrm{~B}$ & EPITOPE & 432 & 432 & 0.408 & . & $\mathrm{K} \mid \mathrm{E}$ \\
\hline QUERY & BEPIPRED $-1.0 \mathrm{~B}$ & EPITOPE & 433 & 433 & 0.740 & . & $\mathbf{A} \mid \mathbf{E}$ \\
\hline QUERY & BEPIPRED-1.0B & EPITOPE & 434 & 434 & 0.743 & . . & S|E \\
\hline QUERY & BEPIPRED $-1.0 \mathrm{~B}$ & EPITOPE & 435 & 435 & 0.576 & . . & $\mathrm{V} \mid \mathrm{E}$ \\
\hline
\end{tabular}




\begin{tabular}{|c|c|c|c|c|c|c|c|}
\hline QUERY & BEPIPRED-1. OB & EPITOPE & 473 & 473 & 0.350 & . & $\mathrm{D} \mid \mathrm{E}$ \\
\hline QUERY & BEPIPRED-1. OB & EPITOPE & 475 & 475 & 0.549 & . & $\mathrm{D} \mid \mathrm{E}$ \\
\hline QUERY & BEPIPRED-1. OB & EPITOPE & 476 & 476 & 0.709 & . & $S \mid E$ \\
\hline QUERY & BEPIPRED-1. OB & EPITOPE & 477 & 477 & 0.982 & . & $\mathbf{T} \mid \mathbf{E}$ \\
\hline QUERY & BEPIPRED-1. OB & EPITOPE & 478 & 478 & 0.687 & . & L $\mid E$ \\
\hline QUERY & BEPIPRED-1. OB & EPITOPE & 479 & 479 & 0.638 & . & $\mathrm{A} \mid \mathrm{E}$ \\
\hline QUERY & BEPIPRED-1. OB & EPITOPE & 480 & 480 & 0.407 & . & $\mathbf{T} \mid \mathbf{E}$ \\
\hline QUERY & BEPIPRED-1. OB & EPITOPE & 510 & 510 & 0.400 & $\cdot$ & $S \mid E$ \\
\hline QUERY & BEPIPRED-1. OB & EPITOPE & 511 & 511 & 0.488 & . & L|E \\
\hline QUERY & BEPIPRED-1. OB & EPITOPE & 512 & 512 & 0.429 & . & $Y \mid E$ \\
\hline
\end{tabular}

\section{Apêndice B: Proteínas idênticas encontradas no banco de dados do NCBI}

\begin{tabular}{|c|c|c|c|c|c|c|}
\hline Source & CDC Region in Nucleotide & Protein & Name & Organism & Strain & Superkingdor \\
\hline ReqSeq & $\frac{\text { NC } 018240.1: 276214-277800}{(-)}$ & $\underline{X P \quad 003859287.1}$ & $\begin{array}{l}\text { mitochondrial } \\
\text { processing } \\
\text { peptidase alpha } \\
\text { subunit, putative } \\
\text { [Leishmania } \\
\text { donovani] }\end{array}$ & $\frac{\text { Leishmania }}{\text { donovani }}$ & $\begin{array}{c}\text { BPK282A } \\
1\end{array}$ & Eukaryota \\
\hline ReqSeq & $\underline{X M \quad 003859239.1: 1-1587(+)}$ & $\underline{X P \quad 003859287.1}$ & $\begin{array}{l}\text { mitochondrial } \\
\text { processing } \\
\text { peptidase alpha } \\
\text { subunit, putative } \\
\text { [Leishmania } \\
\text { donovani] }\end{array}$ & $\frac{\text { Leishmania }}{\text { donovani }}$ & $\begin{array}{l}\text { BPK282A } \\
1\end{array}$ & Eukaryota \\
\hline ReqSeq & $\frac{\text { NC } 009397.2: 273558-275144}{(-)}$ & $\underline{X P} 001464106.1$ & $\begin{array}{l}\text { metallo-peptidase, } \\
\text { Clan ME, Family M16 } \\
\text { [Leishmania } \\
\text { infantum JPCM5] }\end{array}$ & $\begin{array}{l}\underline{\text { Leishmania }} \\
\underline{\text { infantum JPCM5 }}\end{array}$ & JPCM5 & Eukaryota \\
\hline ReqSeq & $\underline{X M \quad 001464069.1: 1-1587(+)}$ & $\underline{X P \quad 001464106.1}$ & $\begin{array}{l}\text { metallo-peptidase, } \\
\text { Clan ME, Family M16 } \\
\text { [Leishmania } \\
\text { infantum JPCM5] }\end{array}$ & $\begin{array}{l}\text { Leishmania } \\
\underline{\text { infantum JPCM5 }}\end{array}$ & JPCM5 & Eukaryota \\
\hline INSDC & $\frac{F R 799600.2: 276214-277800(-}{L}$ & CBZ32575.1 & $\begin{array}{l}\text { mitochondrial } \\
\text { processing } \\
\text { peptidase alpha } \\
\text { subunit, putative } \\
\text { [Leishmania } \\
\text { donovani] }\end{array}$ & $\frac{\text { Leishmania }}{\text { donovani }}$ & $\begin{array}{l}\text { BPK282A } \\
1\end{array}$ & Eukaryota \\
\hline INSDC & FR796445.1:273558-275144 (- & CAM66482.1 & $\begin{array}{l}\text { metallo-peptidase, } \\
\text { Clan ME, Family M16 } \\
\text { [Leishmania } \\
\text { infantum JPCM5] }\end{array}$ & $\begin{array}{l}\underline{\text { Leishmania }} \\
\underline{\text { infantum JPCM5 }}\end{array}$ & JPCM5 & Eukaryota \\
\hline
\end{tabular}


Apêndice C: Enzimas que atuam cortando o gene LDBPK_130760 (código de ref XM_001464069.1) Dados NebCutter.

\begin{tabular}{|c|c|c|c|}
\hline Specificity & Cuts & Specificity & Cuts \\
\hline Aatll & G.ACGTC & FspEI & $\mathrm{CC}(\mathrm{N})_{12} \mathrm{NNNN}_{2}$ \\
\hline Accl & GTMK_AC & Fspl & TGC.GCA \\
\hline Acil & $\mathrm{C} \mathrm{CG}_{2} \mathrm{C}$ & Haell & $R \triangle G C G C Y$ \\
\hline Afel & AGC.GCT & Haelll & $\mathrm{GG} \cdot \mathrm{CC}$ \\
\hline Ahdl & GACNN_N NNGTC & Hgal & $\operatorname{GACGC}(\mathrm{N})_{5}(\mathrm{~N})_{5}$ \\
\hline Alul & $\mathrm{AG} \cdot \mathrm{CT}$ & Hhal & G.CG C \\
\hline AlwNI & CAG.NNN CTG & HinP1I & $\mathrm{G} \mathrm{CG}_{\mathbf{1}} \mathrm{C}$ \\
\hline ApeKI & $\mathrm{GCWG}_{\mathbf{C}} \mathrm{C}$ & Hincll & GTY RAC \\
\hline Avall & GGWC.C & Hinfl & G ANT.C \\
\hline BaeGI & G.KGCM C & Hpall & $\mathrm{C} \mathrm{CG}_{\mathbf{G}} \mathrm{G}$ \\
\hline Banl & G GYRC.C & Hphl & GGTGA(N) ${ }_{7} N^{\top}$ \\
\hline Banll & G.RGCYC & Hpy166II & GTNINAC \\
\hline Bbvl & GCAGC $(\mathrm{N})_{8}$ NNNN & Hpy188I & $\mathrm{TC} \mathrm{N}_{\mathrm{N} A}$ \\
\hline Bccl & CCATCNNNN N & Hpy188III & $T C N N_{2} G A$ \\
\hline BceAl & $\operatorname{ACGGC}(\mathrm{N})_{12} \mathrm{NN}$ & Hpy99I & $\triangle C G W C G$ \\
\hline Bcgl & ${ }_{\Delta N N}(\mathrm{~N})_{10} \mathrm{CGA}(\mathrm{N})_{6} \mathrm{TGC}(\mathrm{N})_{10} \mathrm{NN}$ & HpyAV & $\operatorname{CCTTC}(\mathrm{N})_{5} \mathrm{~N}$ \\
\hline BcoDI & GTCTCN NNNN. & HруCH4III & $\mathrm{AC} . \mathrm{N} \mathrm{GT}$ \\
\hline Bfal & $\mathrm{C} T \mathrm{TA}_{\Delta} \mathrm{G}$ & HpyCH4IV & $A C G . T$ \\
\hline BfuAl & ACCTGCNNNN NNNN. & HруCH4V & $T G . C A$ \\
\hline BfuCl & GATC. & Kasl & GGCGC.C \\
\hline Bgll & GCCN_NNN NGGC & LpnPI & $\operatorname{CCDG}(\mathrm{N})_{10} \mathrm{NNNN}$ \\
\hline Bmrl & ACTGGGNNNN_N & Mbol & GATC. \\
\hline Bpml & CTGGAG(N) ${ }_{14 \_} \mathrm{NN}^{\circ}$ & Mboll & GAAGA $(N)_{7} N^{\top}$ \\
\hline BsaBI & GATNN_NNATC & MluCl & AATT \\
\hline BsaHI & GR CG.YC & Mlyl & GAGTC $(\mathrm{N})_{5}$ \\
\hline BsaJl & $\mathrm{C}$ CNNG.G & Mnll & $\operatorname{CCTC}(\mathrm{N})_{6 .} \mathrm{N}^{\circ}$ \\
\hline BsaXI & ${ }_{\triangle} \mathrm{NNN}^{\prime}(\mathrm{N})_{9} \mathrm{AC}(\mathrm{N})_{5} \mathrm{CTCC}(\mathrm{N})_{7}{ }_{\star} \mathrm{NNN}$ & MspA1I & CMG_CKG \\
\hline BseRI & GAGGAG $(N)_{8} N N$ & Mspl & $\mathrm{C} \mathrm{CG}_{\star} \mathrm{G}$ \\
\hline BseYI & $\mathrm{C}_{\mathrm{CCAG}} \mathrm{C}$ & MspJI & $\mathrm{CNNR}(\mathrm{N})_{9} \mathrm{NNNN}_{4}$ \\
\hline Bsgl & GTGCAG(N) ${ }_{14 \_} \mathrm{NN}^{\circ}$ & Mwol & GCNN_NNN NNGC \\
\hline BsiEl & $\mathrm{CG}_{\star} \mathrm{RY} \mathrm{CG}$ & Nael & GCC.GGC \\
\hline BsiHKAI & G.WGCW C & Narl & $\mathrm{GG} C \mathrm{CG}_{\star} \mathrm{CC}$ \\
\hline BsiWI & C GTAC.G & Ncil & CC S.GG \\
\hline BsIl & CCNN_NNN NNGG & NgoMIV & $\mathrm{GCCGG}_{\star} \mathrm{C}$ \\
\hline BsmAl & GTCTCN NNNN. & NlallI & .CATG \\
\hline BsmBI & CGTCTCN NNNN & NlalV & GGN_NCC \\
\hline Bsml & GAATG.CN & NmeAllI & GCCGAG $(N)_{19 .} N N^{*}$ \\
\hline Bsp1286I & $\mathrm{G} . \mathrm{DGCH} \mathrm{C}$ & Notl & GC GGCC_GC \\
\hline BspCNI & $\mathrm{CTCAG}(\mathrm{N})_{7} \mathrm{NN}^{-}$ & Nrul & TCG.CGA \\
\hline BspMI & ACCTGCNNNN NNNN. & Nspl & R_CATG Y \\
\hline BspQI & GCTCTTCN NNN. & Plel & GAGTCNNNN N. \\
\hline BsrBI & $\mathrm{CCG} . \mathrm{CTC}$ & PluTI & G.GCGCC \\
\hline BsrDI & GCAATG.NN & PspGI & CCWGG. \\
\hline BsrFI & R CCGG.Y & Pstl & C.TGCA G \\
\hline Bsrl & ACTG.GN & Pvull & CAG_CTG \\
\hline BssHII & G CGCG.C & Rsal & GTAC \\
\hline BssSI & C ACGA.G & Sacl & G.AGCT C \\
\hline
\end{tabular}




\begin{tabular}{|c|c|c|c|}
\hline BstAPI & GCAN_NNN NTGC & Sall & GTCGA_C \\
\hline BstNI & $C C W . G G$ & Sapl & GCTCTTCN NNN. \\
\hline BstUI & $\mathrm{CG} . \mathrm{CG}$ & Sau3AI & GATC. \\
\hline BstXI & CCAN_NNNN NTGG & Sau96I & G GNC.C \\
\hline Btgl & C CRYG.G & ScrFI & $C C^{N} \mathrm{GG}$ \\
\hline BtgZI & GCGATG $(N)_{10} N N N N$ & SexAl & A CCWGG.T \\
\hline $\mathrm{BtsCl}$ & GGATG.NN & SfaNI & $\operatorname{GCATC}(\mathrm{N})_{5}$ NNNN. \\
\hline Btsl & GCAGTG.NN & Sfcl & C'TRYA.G \\
\hline BtsIMutl & CAGTG ${ }_{\perp} N^{-}$ & Sfol & GGC.GCC \\
\hline Cac8I & GCNINGC & SgrAl & CR CCGG.YG \\
\hline CspCl & ${ }_{2} \mathrm{NN}(\mathrm{N})_{11} \mathrm{CAA}(\mathrm{N})_{5} \mathrm{GTGG}(\mathrm{N})_{10} \mathrm{NN}^{*}$ & Sphl & G.CATG C \\
\hline CviAll & $\mathrm{CAT}, \mathrm{G}$ & Stul & $A G G . C C T$ \\
\hline CviKI-1 & $\mathrm{RG} . \mathrm{CY}$ & StyD4I & CCNGG. \\
\hline CviQI & $\mathrm{GTA} \mathrm{TA}$ & Styl & $\mathrm{C}^{\circ} \mathrm{CWWG} \cdot \mathrm{G}$ \\
\hline Ddel & C TNA.G & Taql & $\mathrm{T}$ CG.A \\
\hline Dpnl & GATC & Tfil & G AWT C \\
\hline Dpnll & GATC. & Tsel & $\mathrm{GCWG}_{\star} \mathrm{C}$ \\
\hline Drdl & GACNN_NN NNGTC & Tsp45I & GTSAC. \\
\hline Eael & YGGCCAR & TspRI & NNCASTGNN \\
\hline Eagl & C GGCC.G & $X \mathrm{cml}$ & $\begin{array}{c}\text { CCANNNN_N } \\
\text { NNNNTGG }\end{array}$ \\
\hline Earl & CTCTTCN NNN. & Zral & GAC.GTC \\
\hline Ecil & GGCGGA(N) $g_{2} N N^{*}$ & & \\
\hline Eco53kl & GAG_CTC & & \\
\hline EcoP15I & CAGCAG(N) $)_{25} \mathrm{NN}$ & & \\
\hline Fatl & CATG. & & \\
\hline Faul & CCCGCNNNN NN. & & \\
\hline Fnu4HI & $G C N . G C$ & & \\
\hline Fokl & GGATG(N) $)_{9}$ NNNN. & & \\
\hline
\end{tabular}


Color key for alignment scores

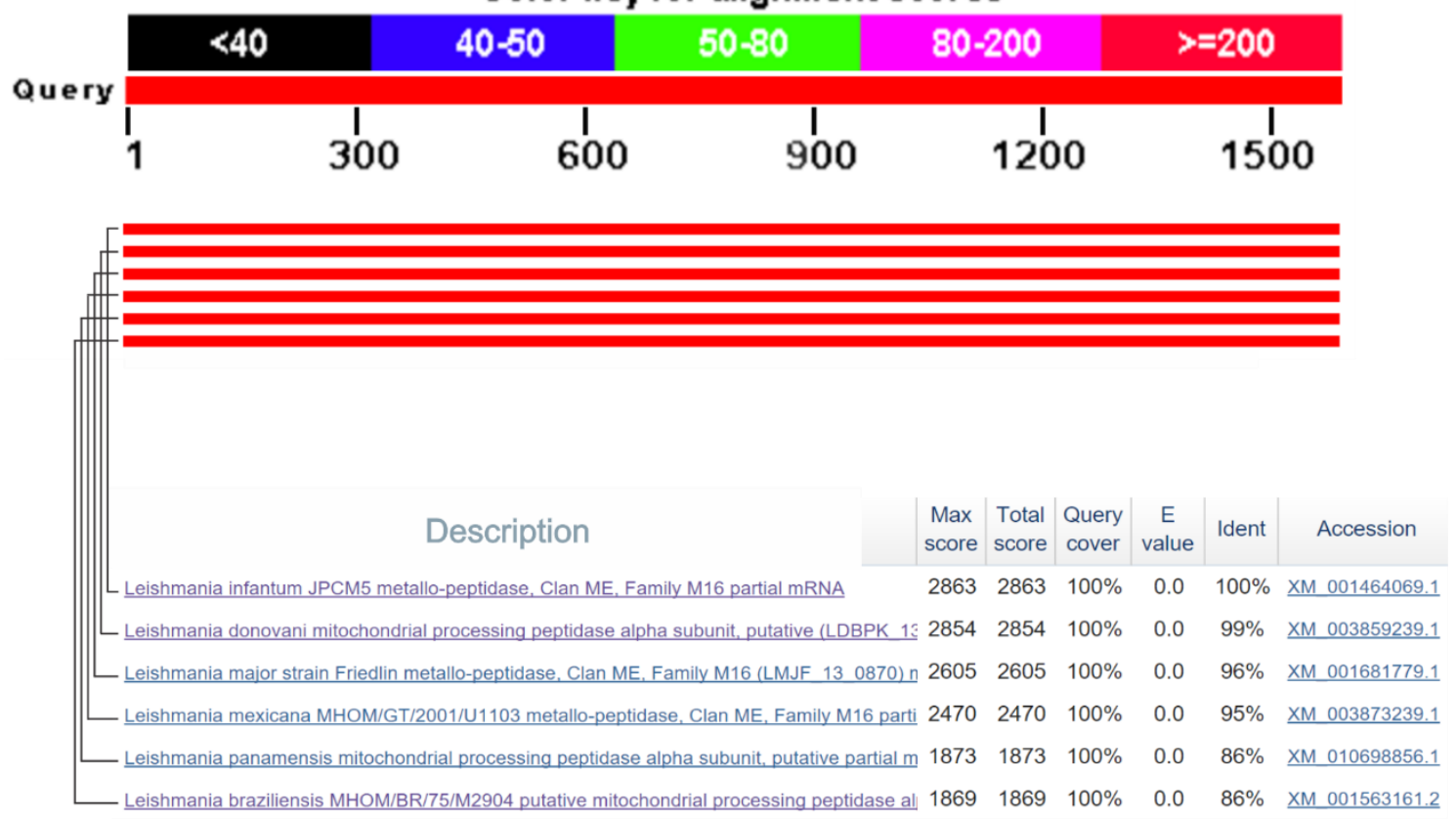

Apêndice D - Sequências com similaridade ao gene LDBPK_130760 (ref XM_001464069.1): Comparação do gene que codifica a proteína XP_001464106.1 com parasitos da família Trypanosomatidae. 


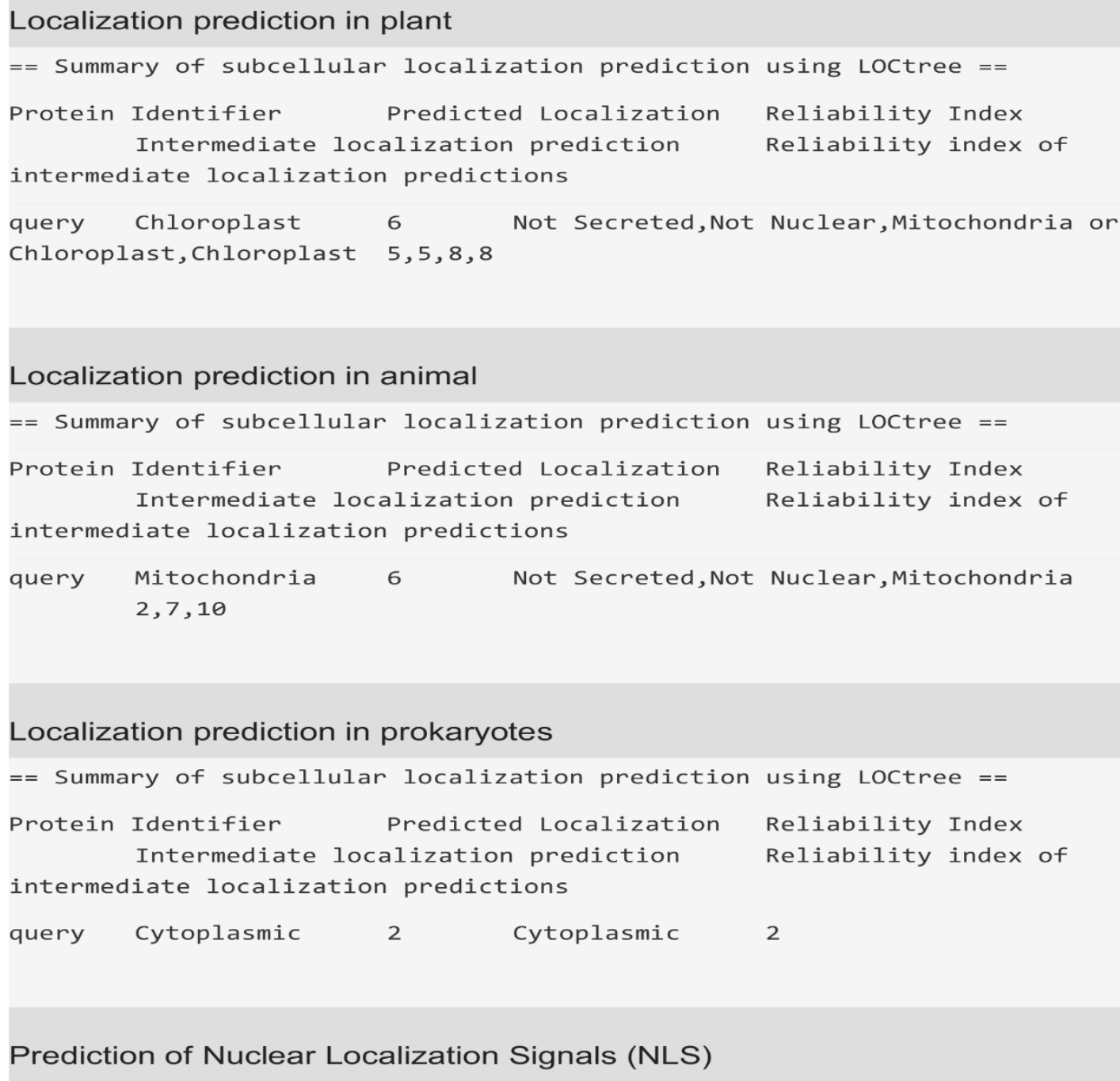

Apêndice E: Predição da localização subcelular da proteína pela ferramenta PredictionProtein. Os dados sugeridos pelo servidor possuem $74 \%$ de precisão para organismos eucariotos que não sejam plantas, $70 \%$ para plantas e $84 \%$ para organismos procariotos. 
Correlaçao Pontos de Acesso e Epitopos Lineares de Celulas B

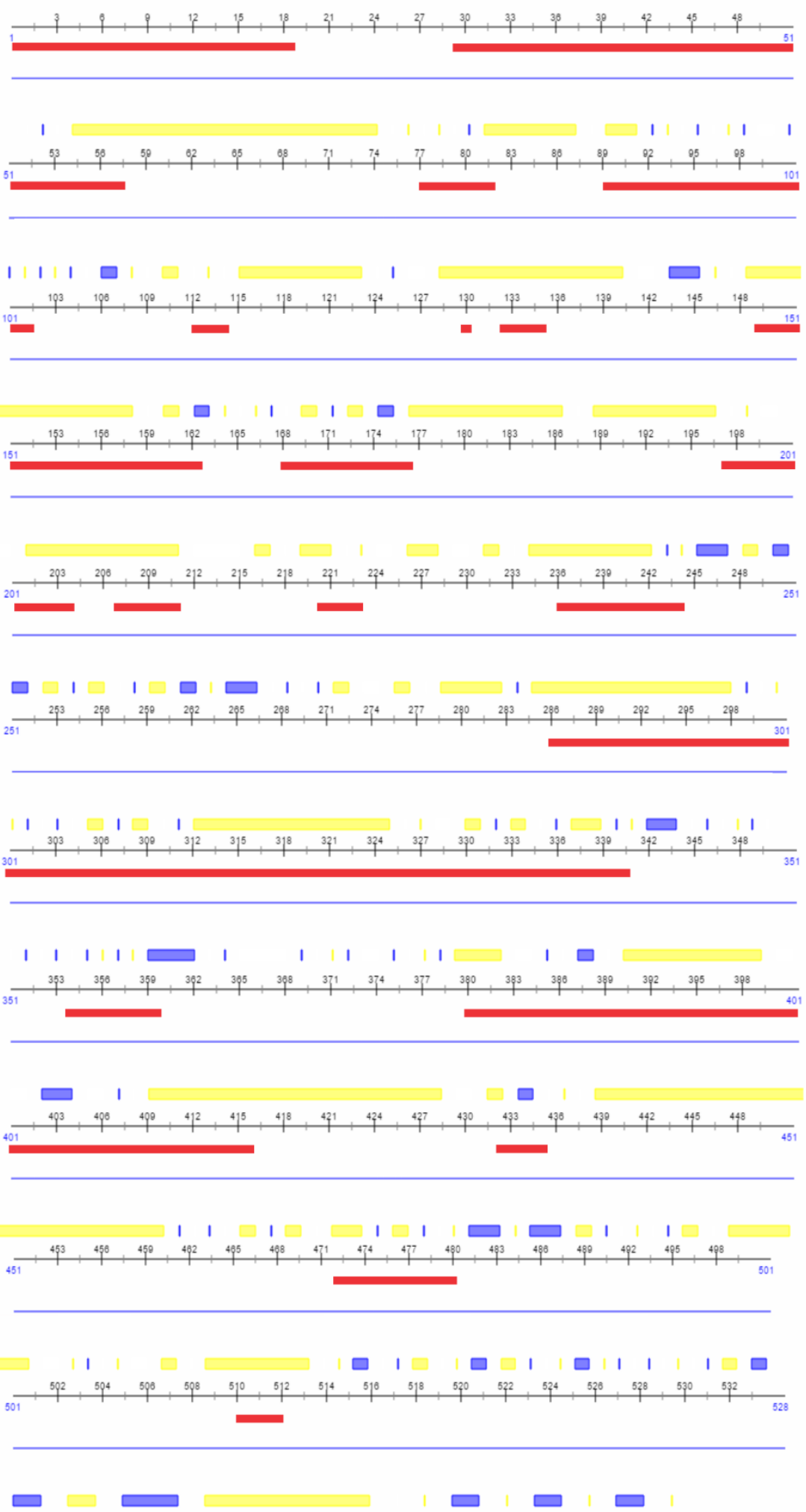

Apêndice F: Correlação dos dados do PredictProtein com BepiPred. Barra em azuis regiões expostas da proteína com acesso ao solvente; Barras em Amarelo, regiões da proteína sem acesso ao solventre; Barras em vermelho, epitopos sugeridos pelos programas de predição; área não marcada entre as cores amarelo e azul correspondem a pontos de acesso intermediários. Ponto de corte padrão BepiPred de 0.35 e; Dados PredictionProtein com Porcentagem de acerto de 72\%. 
A

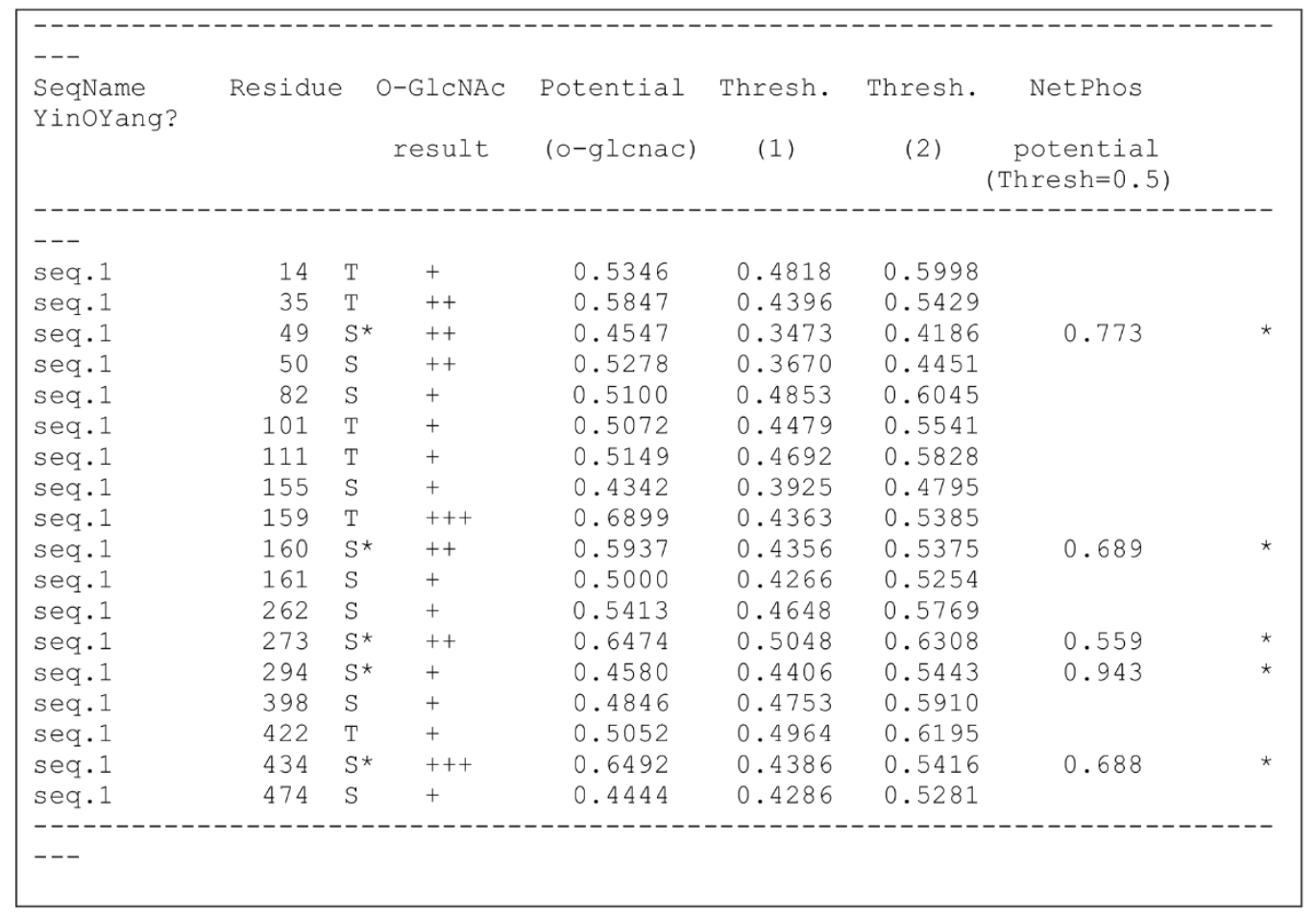

B

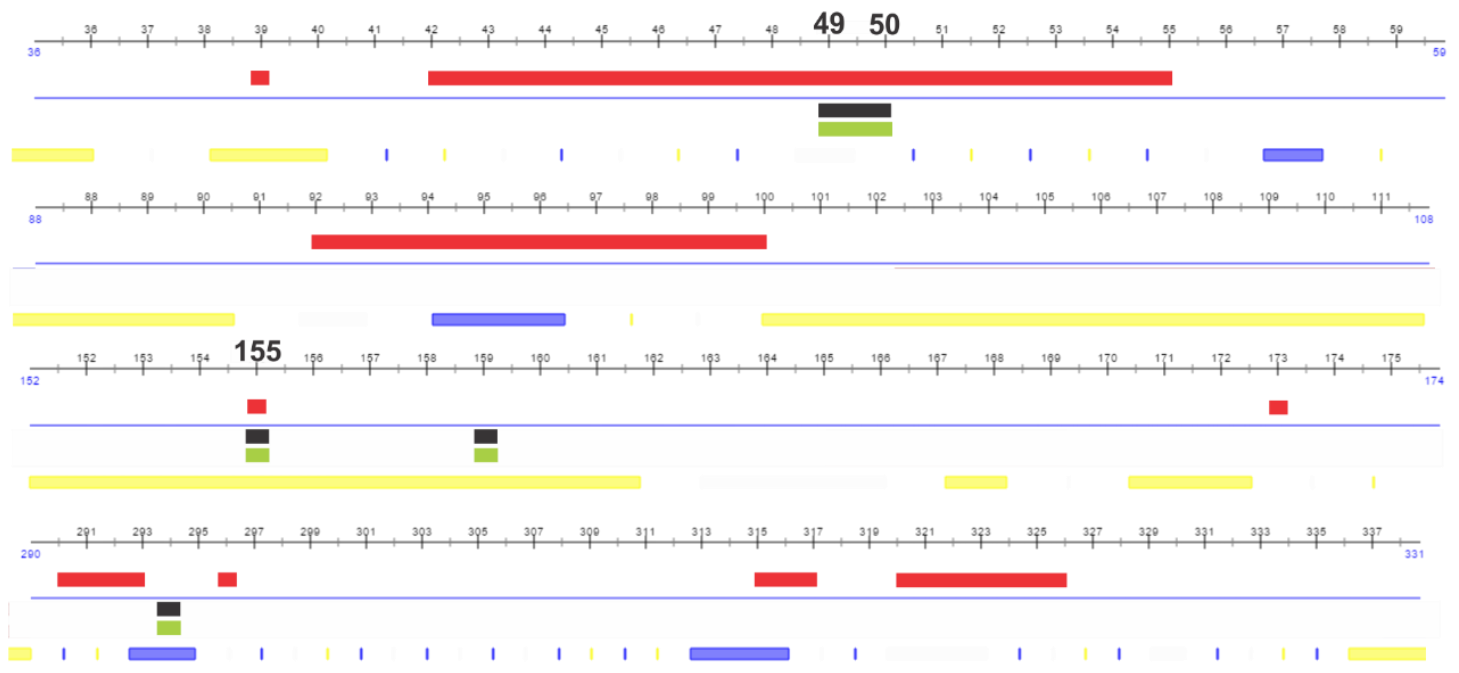

Apêndice G: Correlação dos dados obtidos pela análise in silico. A Correlação entre os dados obtidos pelos servidores NetPhos e YinoYang. B Correlação dos dados da análise in silico. Pontos de acesso ao solvente dos resíduos expostos ao solvente da proteína em Azul; pontos de acesso enterrados ao solvente da proteína em Amarelo; área não marcada entre as cores amarelo e azul correspondem a pontos de acesso intermediários; epitopos lineares para células B sugeridos em vermelho; possíveis sítios de fosforilação em verde e; possíveis glicositios sugeridos em preto. Ponto de corte padrão BepiPred de 0.35 e; Ponto de corte padrão NetPhos de 0.5 e; Dados PredictionProtein com Porcentagem de acerto de $72 \%$. 

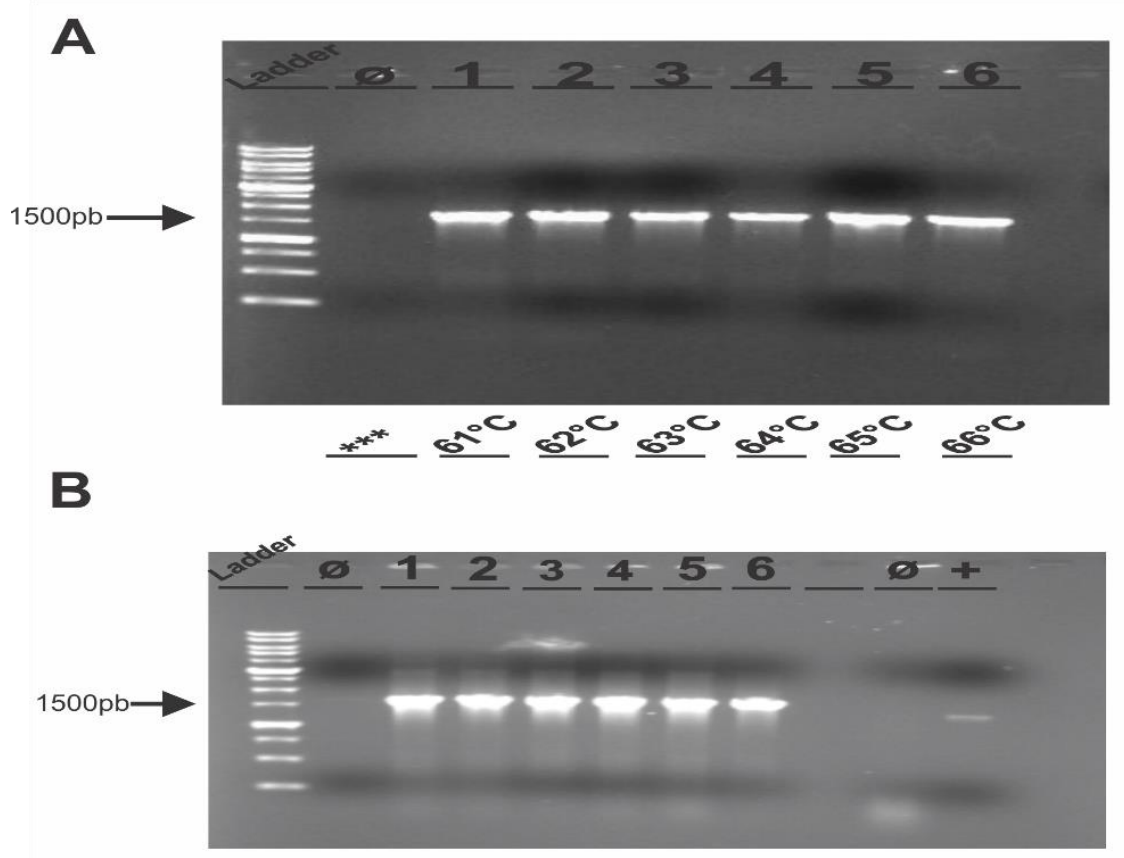

C

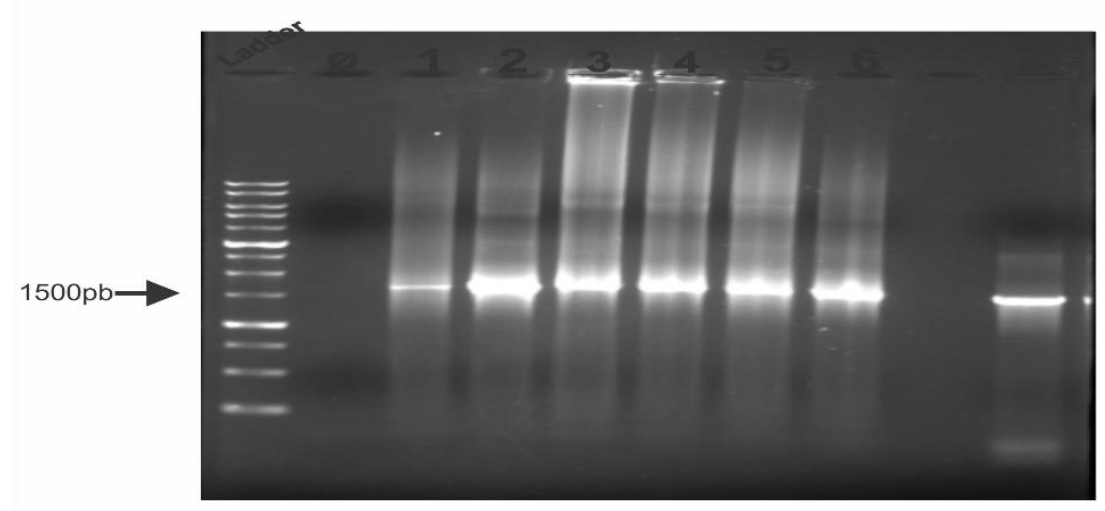

Apêndice H: Padronização das PCRs. A Reações de PCR em diferentes temperaturas de anelamento usando a reação II. Controle Negativo (ø); produtos 1-6 e; Ladder de 1Kb Kasvi. Seta preta indicando banda de altura de $1500 \mathrm{pb}$. B. Análise eletroforética da bactéria transformada. C. Análise molecular por PCR do DNA plasmidial extraído. Ladder $1 \mathrm{~Kb}$ kasvi, Controle Negativo (Ø), clones 01-06, Controle Positivo (+) DNA genômico de Leishmania chagasi. Seta preta indicando banda de 1500pb. 


\begin{tabular}{|c|c|}
\hline \multicolumn{2}{|c|}{ CLUSTAL O(1.2.1) multiple sequence alignment } \\
\hline $\begin{array}{l}\text { Reverso } \\
\text { XM_001464069.1 } \\
\text { Padrao }\end{array}$ & $\begin{array}{l}\text { ATGTTCCGCCGTGTAGTCGCTCCGGCGCCGGTGGCGGCCACCGCAGCCTGCGCTGGGCAG } \\
\text { ATGTTCCGCCGTGAGTCGCTCCGGCCCGTGGCGGCACCGCAGCCTGCGCTGGGAG }\end{array}$ \\
\hline $\begin{array}{l}\text { Reverso } \\
\text { XM 001464069.1 } \\
\text { Padrao }\end{array}$ & $\begin{array}{l}\text { GCTCGCAGCATCTACGAGTACAAGTTCGGTCAGACCCCCCTCACCCAACCGTTTGGCGGA } \\
\text { GCTCGCAGCATCTACGAGTACAAGTTCGGTCAGACCCCCCTCACCCAACCGTTTGGCGGA }\end{array}$ \\
\hline $\begin{array}{l}\text { Reverso } \\
\text { XM_001464069.1 } \\
\text { Padrao }\end{array}$ & $\begin{array}{l}\text { АССTCTCGCCTGCCGCCTGGCCCCTCGTCGAAGCCTGCCCCGGTTGCTGCCGGGAAGGTG } \\
\text { АССTCTCGCCTGCCGCCTGGCCCTCGTCGAAGCCTGCCCCGTTGCTGCCGGGAAGTT }\end{array}$ \\
\hline $\begin{array}{l}\text { Reverso } \\
\text { XM_001464069.1 } \\
\text { Padrao }\end{array}$ & $\begin{array}{l}\text { GAGATCACGAAGCTGCACAACGGCGCGCGCGTCATCACGCACAACCTCGGTGGACCGTCG } \\
\text { GAGATCACGAAGCTGCACAACGGCGCGCGCGTCATCACGCACAACCTCGGTGACCGTCG }\end{array}$ \\
\hline $\begin{array}{l}\text { Reverso } \\
\text { XM_001464069.1 } \\
\text { Padrao }\end{array}$ & $\begin{array}{l}\text { GTGTCCGTTGGTGCCTACATACTCGCCGGCCCCGCCTACGACCCACCGAGCGCGCCGGGC } \\
\text { GTGTCCGTTGGTGCCTACATACTCGCCGGCCCGCCTACGACCACCGAGCGCCCGGGC }\end{array}$ \\
\hline $\begin{array}{l}\text { Reverso } \\
\text { XM_001464069.1 } \\
\text { Padrao }\end{array}$ & $\begin{array}{l}\text { ACGGGAGCCATGATGCACCTTGCCCTGACGACGAGCAACTACAATAATTCGCTGTTCCAG } \\
\text { ACGGGAGCCATGATGCACCTTGCCCTGACGACGAGCAACTACAATAATTCGCTGTTCCAG }\end{array}$ \\
\hline $\begin{array}{l}\text { Reverso } \\
\text { XM_001464069.1 } \\
\text { Padrao }\end{array}$ & $\begin{array}{l}\text { CTTGACCGCAACATTCGCAGTGTCGGCGCCGCCCAGTCGCACTTCGAGAAGCACAAGCAC } \\
\text { CTTGACCGAACATTCGCAGTGTCGGCGCGCCCAGTCGCACTTCGAGAAGCACAAGCAC }\end{array}$ \\
\hline $\begin{array}{l}\text { Reverso } \\
\text { XM_001464069.1 } \\
\text { Padrao }\end{array}$ & $\begin{array}{l}\text { TACATCGGCATTCGCATCGACGCCCGCGCCGACAAGTGGAAGAGCGCCGCGCCGACGTCA } \\
\text { TACATCGGCATTCGCATCGACGCCCGCGCCGACAAGTGGAAGAGCGCCGCGCCGACGTCA }\end{array}$ \\
\hline $\begin{array}{l}\text { Reverso } \\
\text { XM_001464069.1 } \\
\text { Padrao }\end{array}$ & $\begin{array}{l}\text { TCGCTTTCACAGCGGCGGCAGCTGCAGAACCAGAAGCAAGCGGAGCAGCAGTTCTCGTTG } \\
\text { TCGCTTTCACAGCGGCGGCAGCTGCAGAACCAGAAGCAAGCGGAGCAGCAGTTCTCGTTG }\end{array}$ \\
\hline $\begin{array}{l}\text { Reverso } \\
\text { XM_001464069.1 } \\
\text { Padrao }\end{array}$ & $\begin{array}{l}\text { AATCTGGTGCAGGACAACATCTTTACCTGCATCGCCGCGCCCCGCTTCCACGAGCCGGAT } \\
\text { AATCTGGTGCAGGACAACATCTTTACCTGCATCGCCGCGCCCCGCTTCCACGAGCCGGAT }\end{array}$ \\
\hline $\begin{array}{l}\text { Reverso } \\
\text { XM_001464069.1 } \\
\text { Padrao }\end{array}$ & $\begin{array}{l}\text { GTGGAGCGCTTCCGTGACACCATTGACAACCAGGTCGAGGAGCTCCGCTGGCAATGCCCA } \\
\text { GTGGAGCGCTTCCGTGACACCATTGACAACCAGGTCGAGGAGCTCCGCTGGCAATGCCCA }\end{array}$ \\
\hline $\begin{array}{l}\text { Reverso } \\
\text { XM_001464069.1 } \\
\text { Padrao }\end{array}$ & 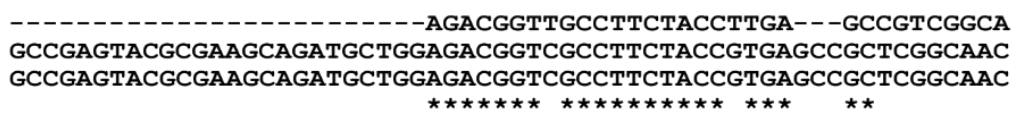 \\
\hline $\begin{array}{l}\text { Reverso } \\
\text { XM_001464069.1 } \\
\text { Padrao }\end{array}$ & 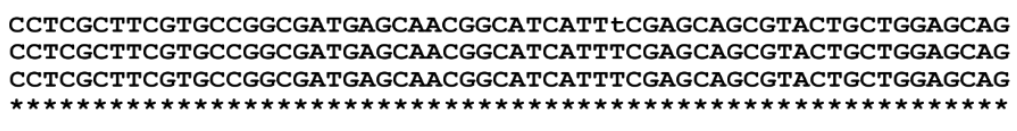 \\
\hline $\begin{array}{l}\text { Reverso } \\
\text { XM_001464069.1 } \\
\text { Padrao }\end{array}$ & 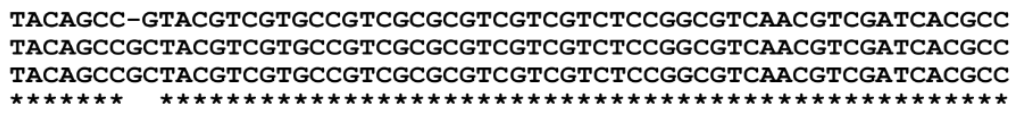 \\
\hline $\begin{array}{l}\text { Reverso } \\
\text { XM_001464069.1 } \\
\text { Padrao }\end{array}$ & $\begin{array}{l}\text { GCGCTGATTGCCGAGTACGAGAACACCCCGTTCCCACACTCCGCCTCGGCACCGCACCAC } \\
\text { GCGCTGATTGCCGAGTACGAGAACACCCCGTTCCCACACTCCGCTCGGCACCGCACCAC } \\
\text { GCGCTGATTGCCGAGTACGAGAACACCCCGTTCCCACACTCCG--- }\end{array}$ \\
\hline
\end{tabular}

Apêndice I: Alinhamento múltiplo do sequenciamento do clone 03 com dados do GenBank. Alinhamento entre a sequência do clone 03 com sequência do gene XP_001464106.1. Sequenciamento com primer padrão T7 (Padrão), sequenciamento com primer reverso SP6 (Reverso) e referência do banco de dado GenBank (XM.001464106.1). ${ }^{* \star *}$ Áreas em comum entre todas as sequencias. 


\begin{tabular}{|c|c|}
\hline \multicolumn{2}{|c|}{ CLUSTAL O(1.2.1) multiple sequence alignment } \\
\hline $\begin{array}{l}\text { Reverso } \\
\text { XM } 001464069.1 \\
\text { Padrao }\end{array}$ & $\begin{array}{l}\text { ATGTTCCGCCGTGTAGTCGCTCCGGCGCCGGTGGCGGCCACCGCAGCCTGCGCTGGGCAG } \\
--- \text { TTCCGCCTGTAGTCGCTCCGGCGCGGTGGCGGCACCGCAGCCTGCGCTGGGCAG }\end{array}$ \\
\hline $\begin{array}{l}\text { Reverso } \\
\text { XM_001464069.1 } \\
\text { Padrao }\end{array}$ & $\begin{array}{l}\text { GCTCGCAGCATCTACGAGTACAAGTTCGGTCAGACCCCCCTCACCCAACCGTTTGGCGGA } \\
\text { GCTCGCAGCATCTACGAGTACAAGTTCGGTCAGACCCCCCTCACCCAACCGTTTGGCGGA }\end{array}$ \\
\hline $\begin{array}{l}\text { Reverso } \\
\text { XM 001464069.1 } \\
\text { Padrao }\end{array}$ & 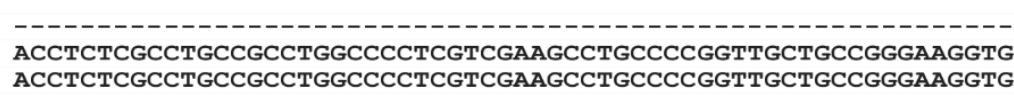 \\
\hline $\begin{array}{l}\text { Reverso } \\
\text { XM } 001464069.1 \\
\text { Padrao }\end{array}$ & GAGATCACGAAGCTGCACAACGGCGCGCGCGTCATCACGCACAACCTCGGTGGACCGTCG \\
\hline $\begin{array}{l}\text { Reverso } \\
\text { XM_001464069.1 } \\
\text { Padrao }\end{array}$ & $\begin{array}{l}\text { GTGTCCGTTGGTGCCTACATACTCGCCGGCCCCGCCTACGACCCACCGAGCGCGCCGGGC } \\
\text { GTGTCCTTGGTGCCTACATACTCGCCGGCCCGCTACGACCCACCGAGCGCGCGGGC }\end{array}$ \\
\hline $\begin{array}{l}\text { Reverso } \\
\text { XM_001464069.1 } \\
\text { Padrao }\end{array}$ & $\begin{array}{l}\text { ACGGGAGCCATGATGCACCTTGCCCTGACGACGAGCAACTACAATAATTCGCTGTTCCAG } \\
\text { ACGGGAGCCATGATGCACCTTGCCCTGACGACGAGCAACTACAATAATTCGCTGTTCCAG }\end{array}$ \\
\hline $\begin{array}{l}\text { Reverso } \\
\text { XM_001464069.1 } \\
\text { Padrao }\end{array}$ & CTTGACCGCAACATTCGCAGTGTCGGCGCCGCCCAGTCGCACTTCGAGAAGCACAAGCAC \\
\hline $\begin{array}{l}\text { Reverso } \\
\text { XM_001464069.1 } \\
\text { Padrao }\end{array}$ & 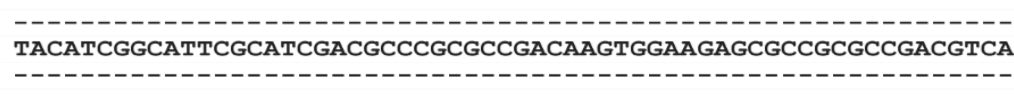 \\
\hline $\begin{array}{l}\text { Reverso } \\
\text { XM } 001464069.1 \\
\text { Padrao }\end{array}$ & TCGCTTTCACAGCGGCGGCAGCTGCAGAACCAGAAGCAAGCGGAGCAGCAGTTCTCGTTG \\
\hline $\begin{array}{l}\text { Reverso } \\
\text { XM_001464069.1 } \\
\text { Padrao }\end{array}$ & AATCTGGTGCAGGACAACATCTTTACCTGCATCGCCGCGCCCCGCTTCCACGAGCCGGAT \\
\hline $\begin{array}{l}\text { Reverso } \\
\text { XM } 001464069.1 \\
\text { Padrao }\end{array}$ & 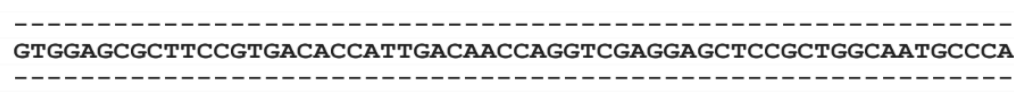 \\
\hline $\begin{array}{l}\text { Reverso } \\
\text { XM_001464069.1 } \\
\text { Padrao }\end{array}$ & GCCGAGTACGCGAAGCAGATGCTGGAGACGGTCGCCTTCTACCGTGAGCCGCTCGGCAAC \\
\hline $\begin{array}{l}\text { Reverso } \\
\text { XM_001464069.1 } \\
\text { Padrao }\end{array}$ & CСTCGCTTCGTGCCGGCGATGAGCAACGGCATCATTTCGAGCAGCGTACTGCTGGAGCAG \\
\hline $\begin{array}{l}\text { Reverso } \\
\text { XM_001464069.1 } \\
\text { Padrao }\end{array}$ & TACAGCCGCTACGTCGTGCCGTCGCGCGTCGTCGTCTCCGGCGTCAACGTCGATCACGCC \\
\hline $\begin{array}{l}\text { Reverso } \\
\text { XM_001464069.1 } \\
\text { Padrao }\end{array}$ & GCGCTGATTGCCGAGTACGAGAACACCCCGTTCCCACACTCCGCCTCGGCACCGCACCAC \\
\hline
\end{tabular}

Apêndice J: Alinhamento múltiplo do clone 5 sequenciado com dados do GenBank. Alinhamento entre do clone 05 (primers LC01/02) com sequência do gene XP_001464106.1. Sequenciamento com primer padrão T7 (Padrão), sequenciamento com primer reverso SP6 (Reverso) e referência do banco de dado GenBank (XM.001464106.1). 


\section{ANEXOS}

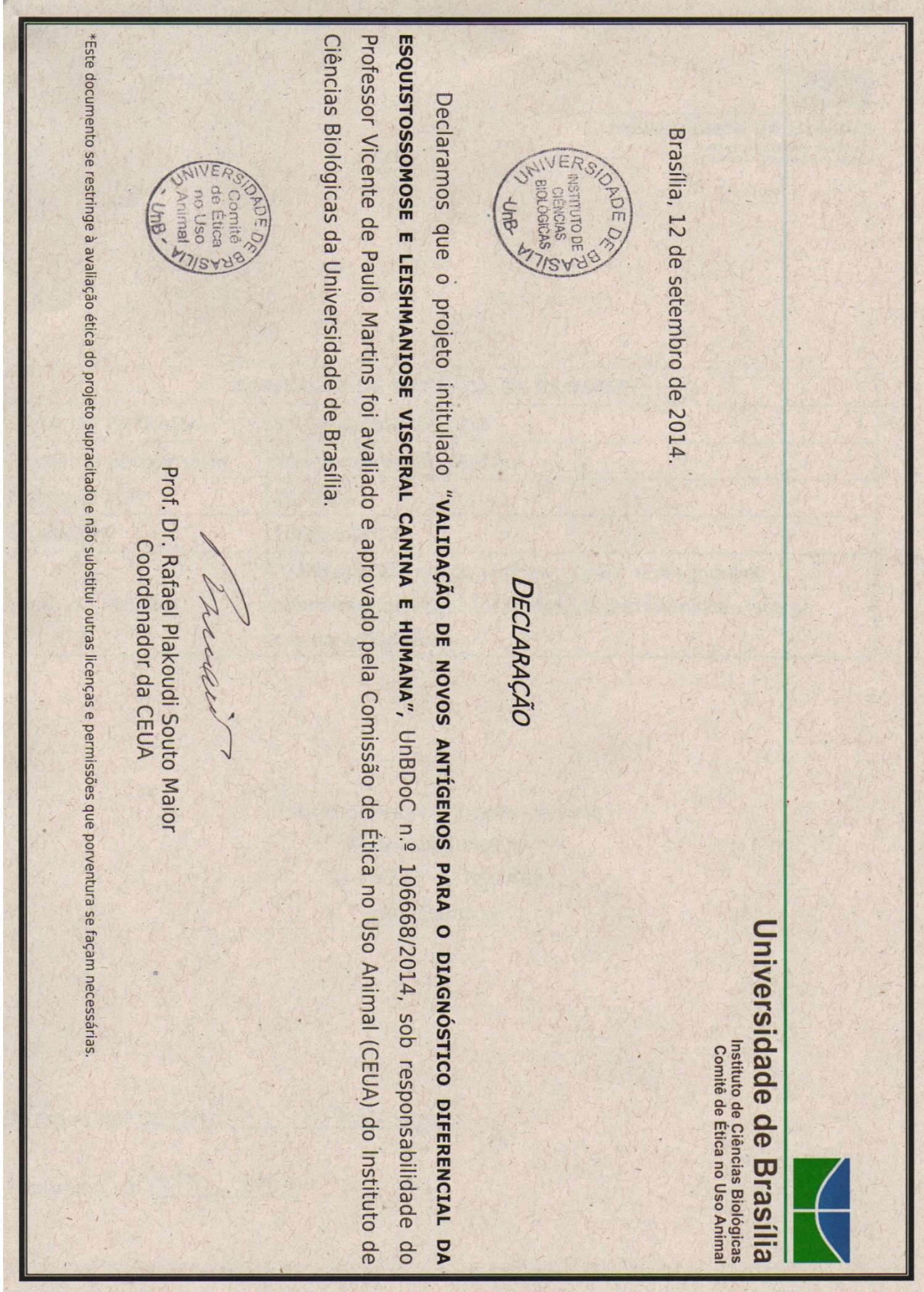

Anexo A: Permissão do Comissão de Ética no Uso Animal. 


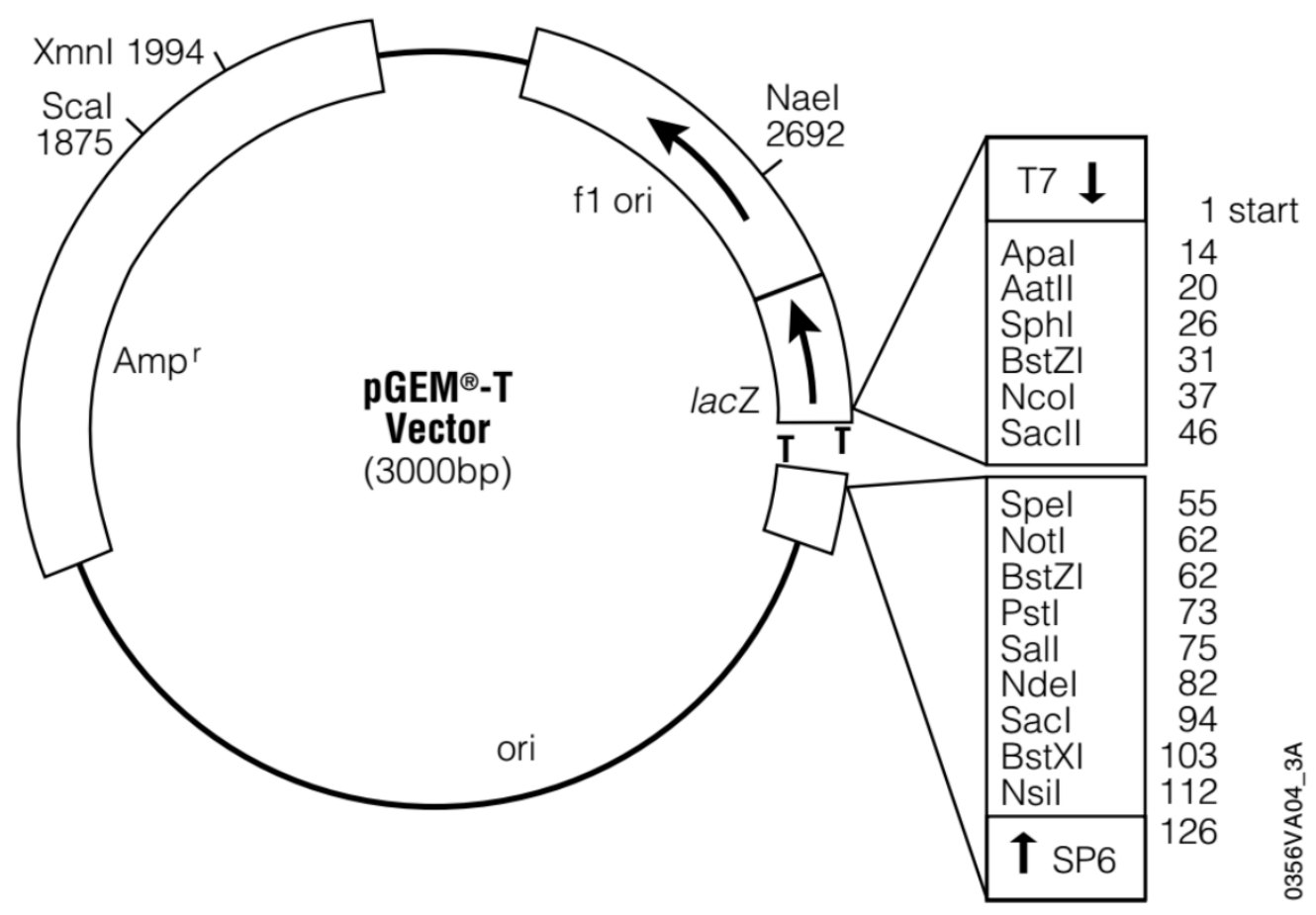

T7 Transcription Start

5'... TGTAA TACGA CTCAC TATAG GGCGA ATTGG GCCCG ACGTC GCATG CTCCC GGCCG 3'... ACATT ATGCT GAGTG ATATC CCGCT TAACC CGGGC TGCAG CGTAC GAGGG CCGGC T7 Promoter

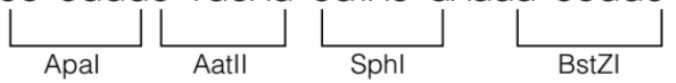

CCATG GCCGC GGGATT3'(cloned insert) ATCAC TAGTG CGGCC GCCTG CAGGT CGACC ATATG

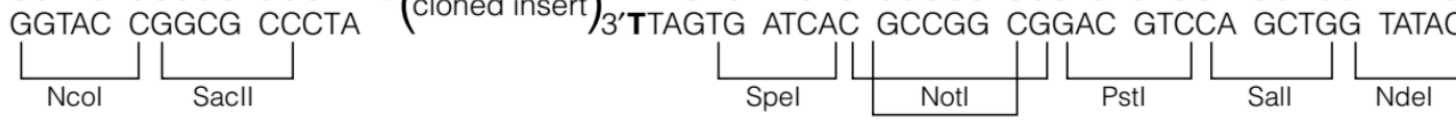
SP6 Transcription Start

GGAGA GCTCC CAACG CGTTG GATGC ATAGC TTGAG TATTC TATAG TGTCA CCTAA AT . . 3' CCTCT CGAGG GTTGC GCAAC CTACG TATCG AACTC ATAAG ATATC ACAGT GGATT TA . . 5'

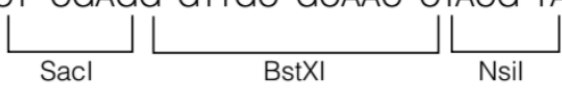
SP6 Promoter

Anexo B: Mapa de restrição do sítio de clonagem do vetor pGEM-T (Promega). 


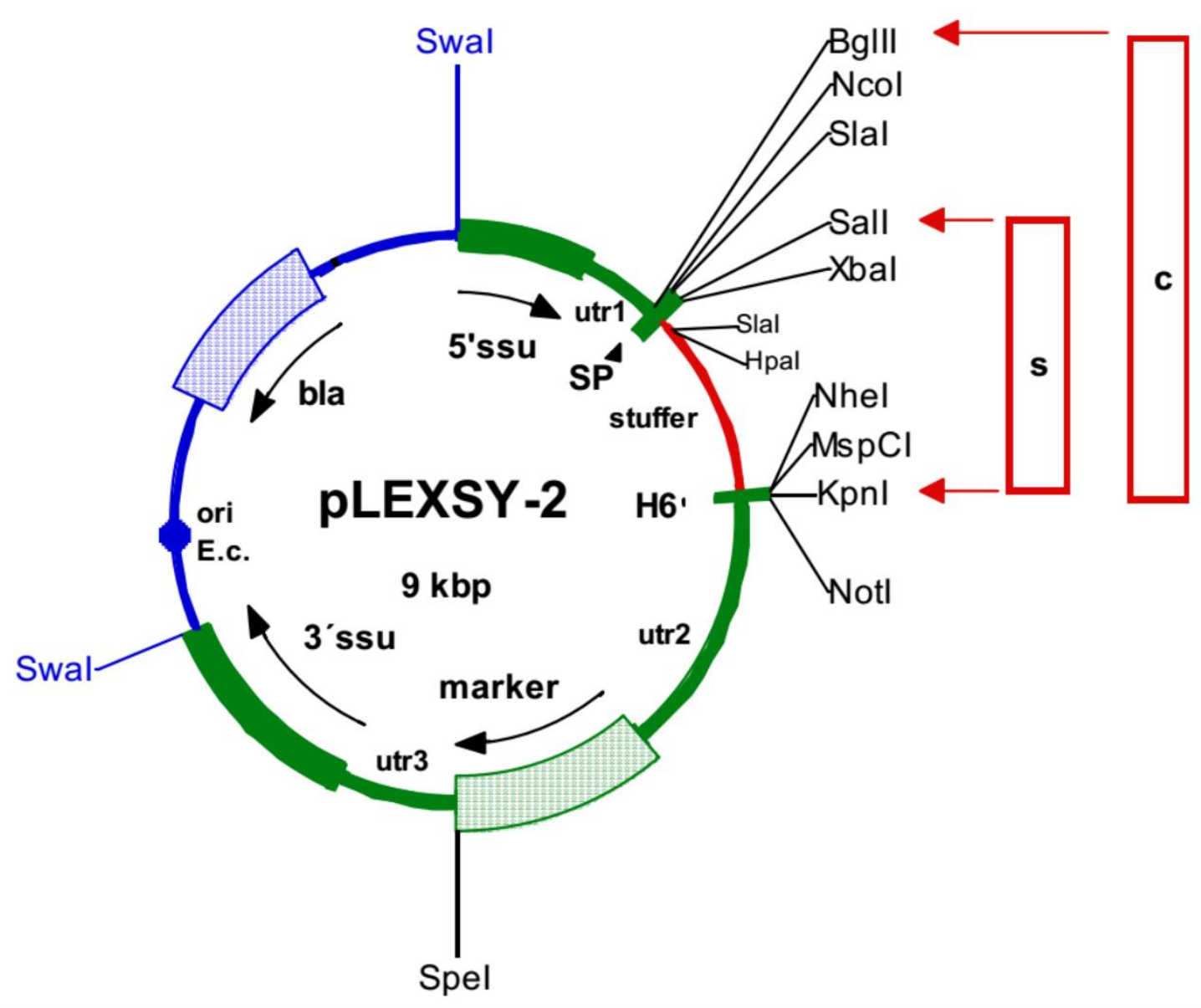

BgllI Ncol Slal

signal peptide

Sall

SPCS Xbal

AGA TCT GCC ATG GCC TCG AGG CTC GTC CGT GTG CTG GCC GCC GCC ATG CTG GTT GCA GCG GCC GTG TCG GTC GAC GCT GGC GCC TCT CTA GAC TCT AGA CGG TAC CGG AGC TCC GAG CAG GCA CAC GAC CGG CGG CGG TAC GAC CAA CGT CGC CGG CAC AGC CAG CTG CGA CCG CGG AGA GAT CTG

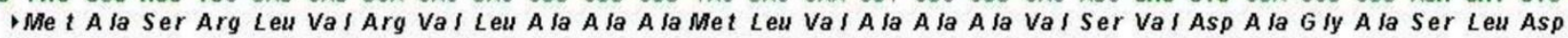

stuffer

Nhel Aflll Kpnl

His6 stretch

Notl

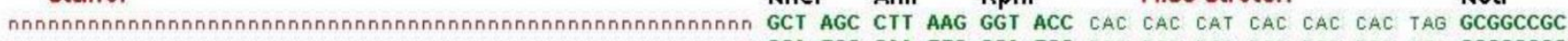

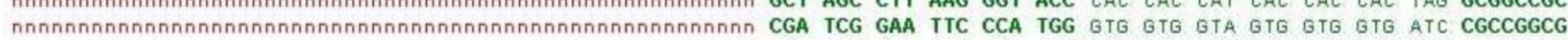
A la Ser Leu Lys Giy $\mathrm{Th} r \mathrm{H}$ is $\mathrm{H}$ is $\mathrm{H}$ is $\mathrm{H}$ is $\mathrm{H}$ is $\mathrm{H}$ is ...

Anexo C: Mapa de restrição do sítio de clonagem do vetor pLEXSY-2 (Jena Bioscience). 

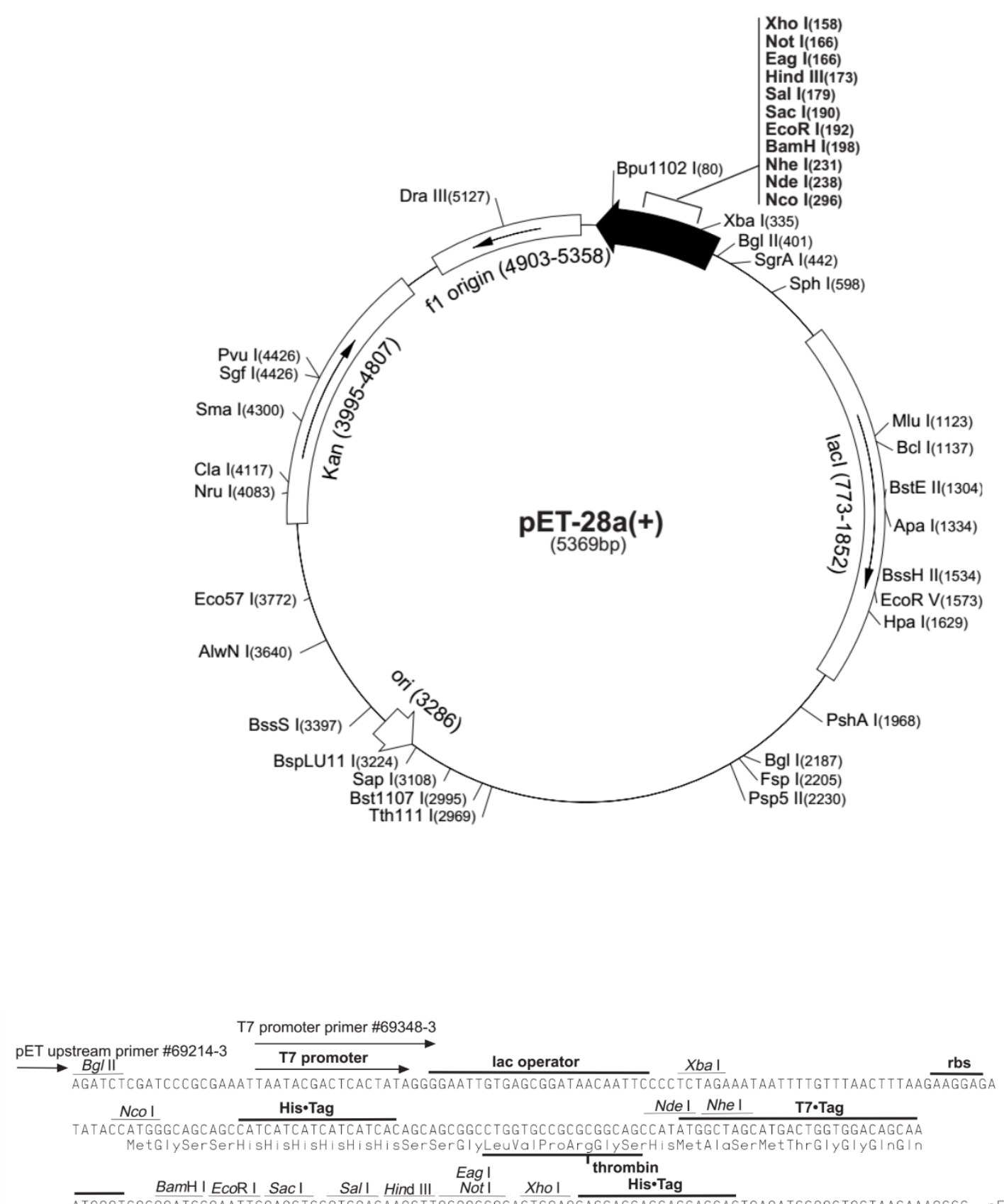

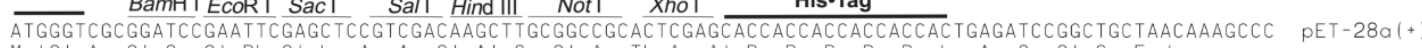
MetG I yArgG I ySerG I uPheG I uLeuArgArgG I nA I aCysG I yArgThrArgA I aProProProProProLeuArgSerG I yCysEnd

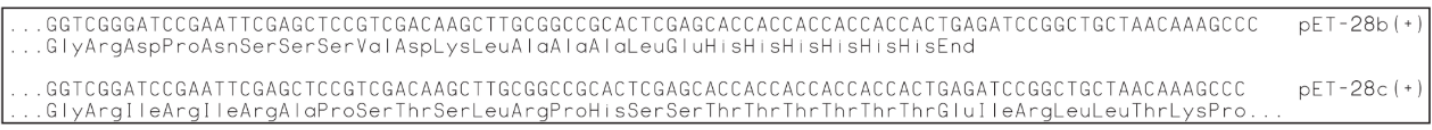

Bpu1102 I T7 terminator

GAAAGGAAGCTGAGT TGGCTGCTGCCACC $\overline{\text { GCTGAGCAATAACTAGCATAACCCCTTGGGGCCTCTAAACGGGTCTTGAGGGGTTTTTG }}$

pET-28a-c(+) cloning/expression region

Anexo D: Mapa de restrição do sítio de clonagem do vetor pET-28a (+) (NovaGen). 